DEPARTMENT OF AGRICULTURE. SPECIAL REPORT-No. 48.

\title{
SILOS AND ENSILAGE.
}

\section{A RECORD}

PRACTICAL TESTS IN

SEIERAL STATES AND CANADA.

W A S II I G TON :

GOVERNMEN'PIINTING OFFICE.

1832. 


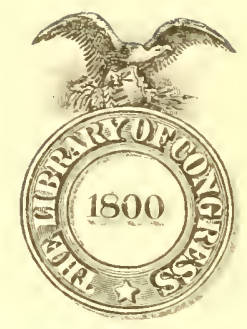

Class

Book 




D'EPARTMENT OF AGRICULTURE. SPECIAL REPORT-No. 48.

\section{SILOS ANI) ENSILAGE.}

A RECORD

()F

PRACTICAL TESTS

IY

SEVERAL STATES AND CANADA.

TIA III I G TON:

GOVERNAXT PIIXING OFFICE。

$185 \%$

$=12 \pi$ 


$$
20
$$

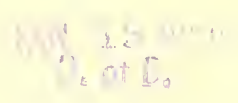




\section{CONTENTS.}

Page.

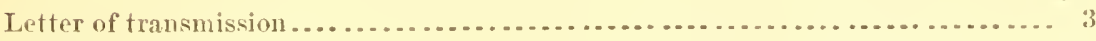

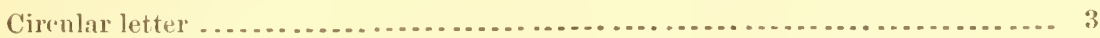

Schednle of questions ................................................ 4

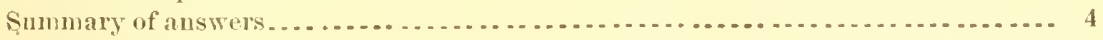

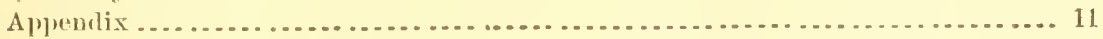

Statement of Arlams, Samucl. .......... Coldlorook Springs . . . . . Mass. ....... 11

Allen, E.................. New Brunswick ......... N. J ........ 11

Allen, Jason.............. Coldbrook Spriugs....... Mass . . . . . . 12

Ames, George II ............ Draent..................Mass......... 13

Atkinson, Edward.......... Boston ................ Mass ........ 13

Ayer, A. C... . . . . . . . . . . . Lowell ................. Mass........ 14

Bartow, H. A., \& Sons ...... Pittsfield............... Mass......... 14

Barker, H. R............... Lowell ... . . . . . . . . . . Mass . . . . . . 15

Bartlett, Fred .............. Shrewsbury ............ Mass........ 16

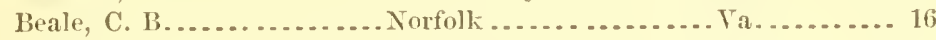

Benelict, E. P............. New York City ......... N. Y ....... 17

Benson, W. B.............. Cardinal .............. Canada ..... 18

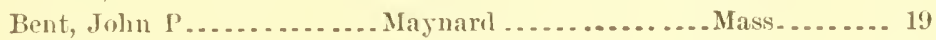

Bisbee, Otis ............... Ponghkeepsie ........... . . ....... 19

Bookstaver, D.............. Syracuse ................ . Y . ...... 20

Brown, H. E. ..............Thetford Centre........ Vt.......... 21

Brown, J. B.............. New York City .......... Y. ...... 21

Ballard, Charles B........ White River Junction . . . Vt . . . . . . . . 69

C'annon, Le Grand B . . . . . . Burlington . . . ........ Vt ......... 22

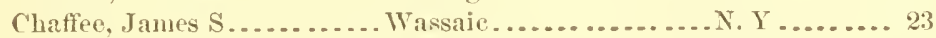

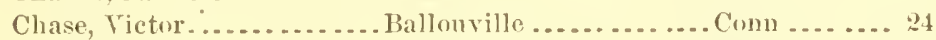

Clemence, George L... . . . . Southbrulge... . . . . . . . Mass . . . . . . 24

Cleveland, A. IR ........... 1)alton ................. Mass........ 25

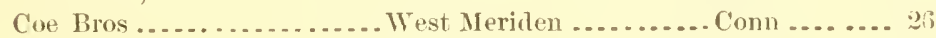

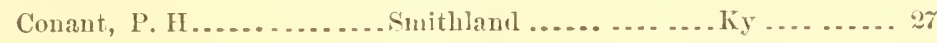

Croniwell, Charles T ....... Rye.................... Y....... 27

Curtis, Dr. L. IV ......... . . Southbridge. . . . . . . . . Mass........ 28

Dorlge, W. A............. Post Mills............. . . . ......

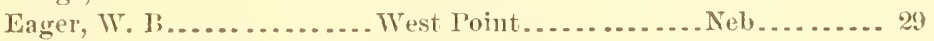

Farnum, Joln R.......... Waltham ... . . . . . . . . Mass . ...... 30

Fish, N. S............... Groton . . . . . . . . . . . . Conn ........ 31

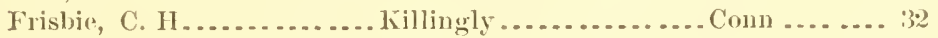

Garrett, C. W ............ Eufield ................ . . . . . . . 32

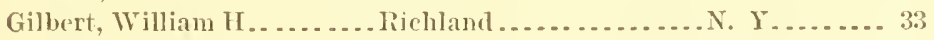

Goodell, D. H.............. Antrim ................ H....... 33

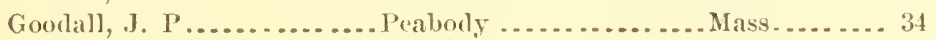

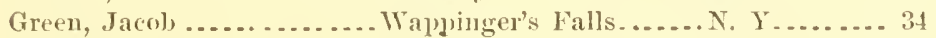

Grilley, .., \& Son......... Wassaic ................. Y....... 35

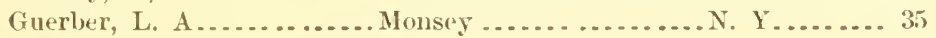

Hammond, Gardner G...... New London ........... Conu ........ 36 
Statement of Hampton Normal Sehool .... Hampton ............ Va ........ 37

Harrigan, J ............... Foxborough . ........... Mass. ....... 37

Henderson, Hon. C. B...... Boston ............... Mass....... 38

Jones, John Winslow ....... Portland ............... . ... ..... 38

Jones, N. P.............. Melrose .............. Mass........ 39

Lapham, Henry ........... Ocnomowoc .......... Wis ........ 40

Leoward Bros.............. Grafton .............. Mass........ 40

Lincoln $13 r o s$.............. Woodstock ............ Vt ......... 41

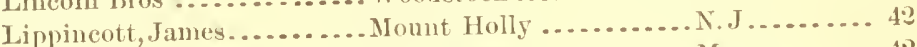

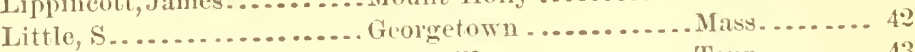

MeBryde, Prof. J. M........ Knoxville.............Tenn ....... 43

Merriam, W. W............. Nuw York City .......... Y....... 44

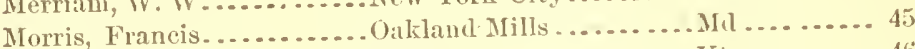

Norton, Capt. G............ Essex ................Vt......... 40

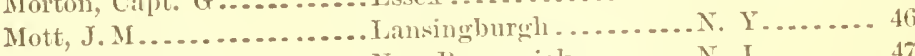

Neilson, James ............. New Brunswick .... . .... . J ........ 47

Plillips, Carpt. John........ Hutson ... . . . . . . . . . . Mass. . . . . . . 47

Pieres, George A ........... Stimstead ............. Cauala ..... 48

Powell, George T...........Ghent.................. . ........ 4.

Pugsley, Jacob ............. Wassaic................. Y....... 49

Reed, Alfred A.............. Providenee.............. R. I......... 50

Roberts, Professor .......... Ithaca ................. . I....... 51

Rogers, J. B.............. Binghampton .......... .. Y....... 52

Root, H. G............... Remington ........... Vt......... $5 i 3$

Seabury, E. K............ Walpole .............. H. ..... 53

Sears Bros. ............... Worcester............ Mass. ....... 53

Skillings, B. F........... . Gray ................. Me ........ 54

Smith, Frameis H.......... Hyattsville ............ Mrl . ....... 5i

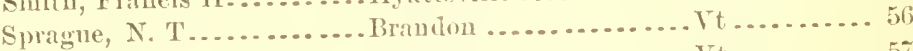

Steblins, Alonzo . .......... V'cruon .............. Vt ......... 54

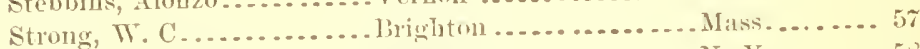

Sweney, Capt. A. H........ West Troy .............. Y....... 58

Tanuer, Dr. W. H......... Wassaic.............. Y...... $5=$

Tarbell, Charles P......... Sonth Royalton ......... . . ........ 59

Thomas, A. T. ............. Franklin 1'ark. ........... J . ...... 59

Thompson, Aaron S....... Mayuari .............. Mass. . . . . . 60

Thompson, A. If., d. Son ... Whoỏville.............. Mass........ 61

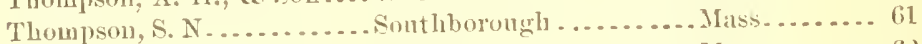

True, L. P...............Hope ................... . . . . . 62

Tuiversity of Wisconsin ... Malison ............. Wis ........ 62

Vilas, $W$. M ............. Burlingtom . . . . . . . . . Tt . ........ 63

Warren, Willian D....... White Plains........... Y. Y.....64

Weeks, L. W.............. Oeommowoc .......... Wis......... 64

West, Charles E.......... Dalton ............... Mass........ (65

Whitman, John D........ Dallas Centre.......... Jowa .... . . 66

Whitnes, Artemas .......... Maynard .............. Mans........ 60

White, George W.......... New York City......... Y.......67

White, William W........Canaseraga ............ Y....... 6

Wullmer, J.A.............Turuer ............... ........ 68

Wright, E............... Pleasant Mills........... J ........ 6 s

Whitin, J. C .............. Whitinsville ...........Mass........ 69 


\title{
SIIOS INI) ENSILAGE.
}

\section{LETTER OF TIANSMISSION.}

\author{
DEPARTALNT OF AGRICLLTURE, \\ Wrashington, J). C., . Jnly 27, 1882.
}

SIR: I have the homor to submit herewith a report on silos and Ensilise.

Copies of a scherlule of questions and an accompanying lettre are appenrled, in respomse to which the materials for a reeorel of mortical tests of silos and ensilage in sereral States and Canala were kindly furnisherl. These statements of men who have built and filled silos and fod ensilage, and a smmmary prepared for the convenience of rearlers, constitute the report.

It was fomm necossary, in preparing the statements for publication, to bring them into the smallest compass that would ahnit plain answers to the questions proposel, and on some points, where the testimony was miform thronghont, much was onitten. Theoretical disenssion, while in many cases deeply interesting, has been generally left out.

The sereral topies treated in the statements and summary are arranged in the same numerieal order as in the schednle of questions, which will serve to indieate the meaning where it is not fully aplarent.

Very respectfully,

\section{Hon. GEo. B. Loring, \\ Commissioner of Agriculture.}

D. M. NESBIT.

SILOS ANI) FNSILAGE.

Unitei, States Departient of Agriculture,

Trashington, D. C., June 10, 1882.

SIR : A growing interest among farmers and dairymen in the preservation of green fodder prompts me to ask the results of your experience and observations in the matter of silos and ensilage. I will thank you to give, in responding to the accompanying rnestions, as full a statement of the results of your experiments as you conveniently can, inclnding any points of interest not embraced in the specific enquiries, which may have come within your observation or knowledge.

Will you also please give the names aud addresses of any persoms you may know who have experimented with ensilage?

I shall be glad to reciproeate your courtesy in any way that may be open to me, and in the event of the publication of a report upon the subject above indicated a copy will be forwarded to your aldress.

Very respectfulls, 
QUESTIONA RELITIVE TO SILOS ANE FNSILAGE.

1. Location of silo with reference to feeding-rooms.

2. Form of silo.

3. Dimensious of silo.

4. Walls of silo-materiak, and construction.

5. Cotier.

6. Weight-naterials nsed for, amomit required, and how applied.

\%. Cost of silo.

8. Crops used for ensilage.

9. Methorl of planting and cultivation.

10. Stage of hevelopment at which follter is most valuable for ensilage.

11. Weight of folder proluest per acre.

12. Find of corm hest for ensililine.

13. Valne of sweet corm as rompared with field varieties.

14. Preparation of forlder for silu-manchiners nsed.

15. Filling the sila.

16. Cost of filling per ton of forleler put in.

17. Lapse of tine before openine the sils.

18. Combition of ensilatge whon ofmenet.

19. leeterioration, if any, after opening.

20. Value of exsilane fim milule cows.

21. Effects of ensilage on dairy proflucts.

22. Value of ensilage for ot her stock.

23. Quantity comsmuerl grer learl.

24. Mothor of feeding-alone, or witl other ford.

25. Comelition of stock fed on ansilage, both as to gain or loss of reight, and health.

26. Protitableness of ensilana, all things considererl.

\section{SILOS AXD EXSILAGE-A STMUARY.}

The following is a smmmary showing the gencral drift of practice and opinion on the several points enmmerated in the sehednle of quostions, of those who have responded to the encuries of the elepartment. It is intended here to give a comprehensive view of the whole subject in the combined light of the statements which appear separately in the appendix :

\section{1.-IOCATION GF SILO.}

I few lare been built at a distance from the stables, but generalle the silos are located with reference to convenience in feeding, in, under, or adjacent to the feeling-rooms. Loeal considerations will determine whether the silo shonla be below the surface, or abose, or partly below aml partly abose. This is not essential. Whele the stables are in the basement of a bank bann, the bottom of the silo may be on the same level, or a few foet below, and the top eren with the mper floor. This arrangement combines the greatest facilitios for filling, weighting, and feeling.

¿̈-FORTI OF SILO.

With rare exceptions the sibos described shom a rectangular horizontal section; a fen have the "comers cut off," and one is octagonal. 
(The eylindrical form, of which there is no instance in the accompanying statements, seems to have obvious adrantages. If nuder gromed, a cylindrical wall is self-supporting against ontside pressme, and may be much lighter than would be sate in any other form. If of wool and above gromel, the walls may be stayed with iron bands. In any case, for a given capacity, the eylindrical form requires the least possible anomit of wall.)

A given weight of ensilage in.a deep silo recpnires less extraneons pressure, and exposes less surface to the air, than it would in a shallow silo. For these reasons depth is imprortant. If too deep there is danger of expressing juice from the ensilage at the bottom.

Where the ensilage is cut lown in a vertieal section for fording, a narrow silo has the advantage of exposing little surface to the air.

$$
\text { 3.- YAPACITY OF SILO. }
$$

The silos reported rary in capacity from 36.4 to 19,200 cubir feet. If entirely full of compresserl ensilage the smallest womld hold 9.1 and the larest 480 tous, estimating 50 pouncls to the cubic foot. Practically, the capacity of a silo is less to the extent that the ensilage settles moler pressure. This should not exceed one-tomth. thongh in shallow silos, or those filled rapidly and with little treading, it is likely to be much more. A temporary eno is sometimes added to the silo proper, so that the latter may be full when the settling ceases.

$$
\text { 4.-WALLS OF SILO. }
$$

For walls moler gromml, stone, brick, and concrete are nsed. The eloice in any case may safely depend on the cost. In tirm soils that do not become satmated with water, walls are not essential to the presereation of ensilage. Abore glomm, two thicknesses of inch-boards, with shathing laper between, (the latter sairl, by some, to be muecessary), seem to be sufficient, if supported against lateral pressure fiom the ensilage.

\section{5.-COYER.}

A layer of straw or hay will serve in some measure to exclude air, but is not necessary. Generally boards or planks are placed directly on the ensilage. 'The cover is sometimes male in sections "2 feet, or more wide; oftener each plank is separate. The cover is generaliy put on transversely, having in view the nucovering of a part of the silo while the weight remains on the rest. Rongh boards, with no attempt at matching, have been nsed successfully. A little space should be allowed between the walls and cover, that there may be no interfirence as the settling progresses. (Nee Remarks.)

\section{6.-WEIGIIT.}

Any heary material may be used. The amount required depends on various conditions. It will be noticed that practices and oplunions differ 
widely. The object is always to make tho ensilage compact, and thereby leave little room for air, on which depend fermentation and decay. In a deep silo the greater part is sufficiently compresserl by a few teet of ensilage at the top, so that there is small perentage of waste, even when no weight is appliel above the ensilane. Screws are nsed by some insteal of weights. The objection to then is that they are not self-acting, like gravity.

$$
\text { 7.- } \cos \mathrm{T} \text {. }
$$

The cost of silos, per ton of eapacity, varies finm $\$ 4$, or $\$ 5$, for walls of heary masomy and smperstruetmes of chabolate finish, and 50 cents or less for the simplest woolen silos. Earth silos, without wall, can be exeavater with plow and seraper, when other work is not pressing, at a trifling cost. (Nee liemarlis.)

\section{8.-CROPS FOR HNAILAGT.}

Corn takes the learl of ensilage erojs. lige is grown by many in con. nection with corn-the same ground frorlucing a "lol) of cach in a season. Oats, sorghum, Hnmgarian grass, field peas, clorer-in fact, almost every erop nseel for soiling has been stored in silos and taken ont in good condition. There are indiations that some materials have their. value enhanced by the fermentation of the silo, while in others there is loss. The relative values for ensilage, of the different soiling crops, can only be determined thengh eareful tests, often repeated, by pratical mell.

All thoughtenl farmers would be glad to get more value from the bulky "fodder" of their corn crops than is fomut in any of the common meth. ods. There are aceonnts of plucking the ears when the liernels were well glazed, and putting the fodiler into the silo. The value of such ensilage, and the loss, if any, to the grain are not sufficiently ascertained to warrant positive statements.

\section{9.-PLANTING AND ClLTIYATION.}

Thorongh preparation hetorr planting is essential. Corn, sorghum, and similar copss shonld be planted in rows. The quantity of seed corn raries from eight quarts to a bushel and a hall for an arese. A smoothing harrow does the work of cultivating perfectly, and with little expense, while the (on'n is small.

\section{0. - WILX GROPS ARE AT THEIR BEST FOR ENSLLAGE.}

The common practice is to punt erous into the silo when their full grow th has been reateher, and hefor ripening begins. Manifestly, one rule will not answer all pmomes. Thestock to be ferl and the object in feeding must be consisleresl in determining when the arop should be ent. On this point must alenemb mmch of the value of eusilage. 


\section{1.-TIELD OF ENSILAGE CROPS.}

Com produces more fodder per ace than any other erop mentioned. The arelage for corn is not fur from 20 tous-which speaks rrell for land and culture. The largest yield from a single acrowas 58 tous; the average of a large aldea on the same fam was only $12 \frac{1}{2}$ tons.

\section{2.-KIND OF CORX BEST FOI ENSILAGE.}

The largest is gencrally preferred; hence seed grown in a warmer elimate is in demant.

\section{3.- SIFEET CORN FOI ENSILAGE.}

It is conceded by many that the fodeler of sweet corn is worth more, pound for pouml, than that of larger kinds, for soiling: Some hold that the same superiority is retainer in the eusilage, while others think that the adrantage after fermentation is on the other side. The sweet rarieties generally do not gield large erops.

\section{4.-PREPARING FODDER FOR THE SILO.}

The mowing-machine is sometimes used for cutting corn in the fieldoftener the work is done by hand. Varions cutters, laving carriers attached for elevated silos, ane in use and are generally driven by horse, steam, or water power. Fine cutting-a lalf inch, or less-is in favor. It packs closer, and for this reason is likely to keep better than coarse ensilage. Fodder of any lind may be put in whole, and, if as closely compressed as cut fodder, will beep as well, if not better; but it requires much greater pressure.

\section{5.-FILLING THE SILO.}

During the process of filling, the ensilage should be liept lecel, and well trodden. A horse may be used rery effectively for the latter. Soms attach much importance to rapid filling, while others make it more a matter of convenience. With the packing erually thorough, rapid filling is probably best.

$$
\text { 16. - COST OF FILLING THE SILO. }
$$

The eost, from tield to silo, is varionsly reported, flom 35 cents-and in a single instance 10 or 12 cents-for labor alone, to s.2 and wpwards per ton; though the higher anomits include the entire cost of the crop, not the harresting alone. There is a general expectation that experience will hring a considerable reduction in the cost of filling.

It is probable that, with a more general adoption of ensilage, the best machinery will be provided by men who will malie a business of filling silos. This could hardly fail to lessen the eost and bring the benefits of the system within the rrath of many who otherwise would not begin. 


\section{7.-TINIE FROAL FILLING TO OPENIXG SILO.}

The ensilage should remain nuler pressure at least until cool, and be uncoverel after that when wanted.

\section{8.-CONDITION OF ENSILAGE WILN OPENED.}

In nearly all cases the loss by decay was very slight, and confined to the top and sides where there was more or less exposme to air.

\section{9.-DETERIORATIOX AFTER OPENIXG.}

Generalls the ensilage has liejt perfectly for several months, showing 110 deterioration while any remaned in the silo, excepting where exposer for a considerable time. It is better to nucover a whole silo, or compartment of a silo, at once, and thus expose a uew surface each day, than to cut down sections.

\section{0.-TALTE OF ENSILAGE FOR MILUII COW'S.}

Ensilage has been fed to mileh cows more generally than to any other class of stock, and no mnfarorable lesults ale leported. There can be little doubt that its encatest value will always be foumd in this eonnection. Several feeder's consiler it equal in value to one-third of its weight ot the hest hay, and some rate it higher.

\section{1.-EFPECTS ON D.MIR Y PRODECTS.}

There is a marked increase in yuantity and improvement in quality of milk and butter after changing from dry feed to ensilage, corresponding with the effects of a similal change to fresh pasture. A few seeming exceptions ale moted, which will probably find rxplanation in defects easily remedied, rather than in such as ale inherent.

$$
\text { 2.2.-YALTE FOR OTHER STOCK. }
$$

Ensilage has leen fed to all classes of farm stock, inchuling swine and poultry, with results almost mitormly favorable. Exceptions are noted in the statements of Messis. Coe Bros., and Hon. C. B. Henderson, where it appears that horses were injurionsly atfecterl. It shonld be borme in mind in this connection that ensilage is simply forage preserved in a silo, and may vary as much in quality as lay. The ensilage that is best for a milch cow may be injurions to a horse, and that on which a horse would thrive might render a poor return in the milk-pail.

$$
\text { 23.-DAILY RATION OF EXSILAGE. }
$$

Cows giving milk are commonly fed 50 to 60 pounds, with some dry fodiler' and g'rain.

$$
\text { 24. -IIETHOD OF FIEDING. }
$$

Experiments have been made in feeding ensilage exelusively, aud results have varied with the quality of ensilage and the stock fed. It is 
certain that ensilage of corn cut while in blossom, or earlier, is not alone suflicient for mileh cows. It is best to feerl hay once a day, am some grain or other rich food, muless the latter is smpledied in the ensilage, as it is when corn has reached or passed the roasting-ear stage lofore cutting. Ensilage, as it is rommonly understood, is a sulstitute for laay and coarse fodder generally, and does not take the place of grain.

$$
\text { 2.5.-TIE CONDHION WF STOCK FEU (IN EXSILAGE, }
$$

botlı as to health and gain in weight, has heen miformly favorable.

$$
\text { 20.-PRONITABLENESS OF ENSILAGE. }
$$

There is hardly a doubt expressed on this point-certainly not a dissenting opinion.

Rourdiss.-The general use of ensilage must depend largely on its cheapness. Costly silos and expensive machinery must always be insurmomntable obstacles to a majority of farmers. For this leason, experience tending to show what is essential to the preservation of fodder in silos, is of the first importance.

Especial attention is invited to the earth silos mentioned in the statement of Francis Morris, esq., of Uakland Manor, Mu. Mr. Morris is a pioneer in ensilage in Anerica, his first silos having been built, and filled, in 1876. These were in the basement of his barn, walls of masomry. The next year he mate a trench in sloping ground so that a cart could be backed in at the lower end for conveying ensilage to the feeding-room. The sides are sloping and the average depth does not exceed six feet.

The cost is simply the cost of eligging a ditch of similar dimensioms This trenel was filled in $187 \pi$ and regularly since, and has kept its eontents perfectly. Mr. Morris has several silos of the same kind, in different places, for convenience in filling. Ile uses a large entter driven by a stean engine, and packs in the silo by treading with horses. The filling is earried several frect above the surface of the ground, and romnded up at the center, the excarated earth serving to confine the ensilage. The covering is first roofing-felt, then earth for weight.

Mr. Morris has pnt in whole fodder and it has kept perfectly. He ents it fine, mainly for convenience in handling and feeding. Whole fodder should be laid across, rather than lengthwise in the trench, so that it can be taken out easily.

In order that the extent of Mr. Morris' operations may be muderstood, it is proper to add that his estate of Odkland Manor comprises about 1,700 acres. His wheat erop this year, 1852 , was 5,000 bushels, and his com is expected to reach the same figures. The meatlows yicld upwards of 200 tons of hay ammully. The stock consists of 50 horses and mules, 100 cattle, 500 sheep, and 50 hogs. And as the whole is managed on business principles, Mr. Morris very justly esteems his earth silos of primary importance. 



\section{IPPINIX}

The followiug statements lave been fumished, in response to encuiries of the bepartment, by men who have huilt and filted silos and ferl ensilage. The numbers inlicate topies which are arranged in the same orter as in the schedule of questions:

SAMUed ADAMs, Colubrowk Springs, Mass.:

1. Adjoiniug barn.

3. $36 \times 16$ feet: drpth, 12 tret.

4. Stome wall faced witl cement.

6. 900 pounds stone to the square yarl.

7. Abont \$300.

8. Corn.

10. When the blossom hegius to fall.

11. 25 tons.

1:. Frefer Blount's on account of 'puantity.

14. Cut inch. C'stel sterim.

16. About 75 eents.

17. Two montles.

18. Color changed to lorown, lont in gool condition where properly weighted.

20. The most economical feed we can raiso; valne one-third of good hay.

21. I saw no bat effects on stock or product.

23. 60 pounds per day.

24. For mileh cows I should feed 50 poumds ensilage, 10 pounds hay; if shorts were not two high, would feed two quarts per day, and if the dairy prodnot was in demaud wonld give a little meal of some kiud.

25. Oxen and young stock showed a grood gain in growth and health.

26. I wintered 43 leat of stock where I usually had 35. IIave sold \$200 worth of hay aud still have 5 tons left; but I am couvinced we have something yet to learn.

\section{E. Allex, New Brunswiek, 1. J.:}

1. Adjoining and opening into.

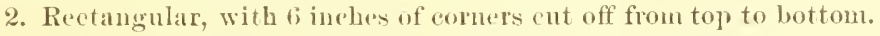

3. Two commartments, each $13 \times$ x 19 teet, and 19 feet deep.

4. Concrete, one part Rosendale centent to four aud a half of sharp, gravelly sand, wet with heary white-wash, mate by slacking quick-lime muler water two days provions to msing. All the field stome that ean be put in are emberled in the cement in the well.

6. Field stome, 150 poumds to spmiste foot.

7. About 50 of, exclusive of root:

๖. Corn.

9. Sow with grain dr:11, two rows at once, thee feet four inches apart. Cultivate to keep sromml loose and fiee firom weals.

10. When the kermel is in the milk.

12. Blount is Prolitic. Furthen trial necessary.

14. Cut $\frac{8}{8}$ incl. Cutter rnu by a two-horse tread-power. 
15. Carried from cutter into silo with elevator, two men in silo to level and treal.

16. Hbont 75 cents per ton, includiug cutting in the field and cartiug.

17. Six weelis.

1-. Top, $\frac{1}{2}$ to 1 inch imperfect; below appeared like cooked forder ; smell of Tew Orluan inolasses; sermed perfeet.

?11. Think it bettre than any other kind of fodter. Cows prefer it tolvewer's graiu.

?1. It makes rich uilk, more wholesome for children than grass mill.

2:3. 41) pounds per letal per day.

24. Mix with 5 or 6 ponnds of mill-feed, or 3 pounds of corn, or cotton-serel meal with 2 or 3 poumils of wheat shorts or hran.

25. I attle take on thes rapidy; keep in good condition as to health and flesh.

:20. believe ensilanging the best and cheapest wode of preparing or preserving cornfocliler.

JAsox AlLex, r'oldbrook springs, Mass.:

1. Opening into basenest of baru, 4 feet alowe bottom of silo.

:3. 2- $x$ 1: teet, mison work 11 fert high. with 4 feet of wool on top.

5. Plank.

6. Six incless of stone.

7. S3:2t.51, ineluting averything.

$\therefore$ ('or'll.

9. Light soil: inverter sol : on one are 15 loads of harn-yard manure, and 25u poundo of phoslate. Drilled send half busled per acre; rows 3 feet apart; harrowed twice witl smothing harow, after this want through with horse-hoe once in seven or eight days until corn was 4 feet high. Two acres more had same cultivation withont harn-yard nuanul't.

10. When the latest is in full bloom, and the most forward has ears well formed.

11. On three acres 47 toms ; on the one are with barn-yard manne, 20 toms, and on the other two inces. 25 tons.

12. Tlue larest linel of southerue corn.

14. ('ut three-fonths of an inch long: used a one-horse tread-power.

16. Cost of raising and istoring three acres (fy tous) of ensilage eorn.

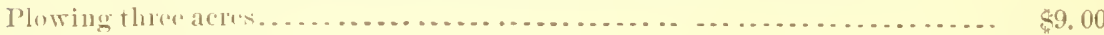

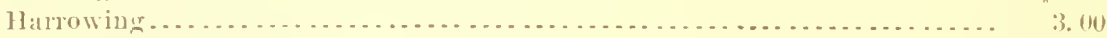

Commereial fertilizels ... . . . . . . . . . . . . . . . . . . . . . . . . . . . 20. 00

Fifteen loads of mammo, one-halt eluarged to the corn . . . . . . . . . . . . . 15.00

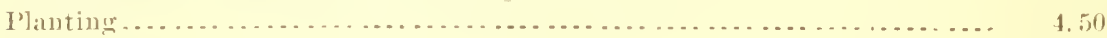

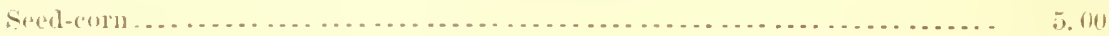

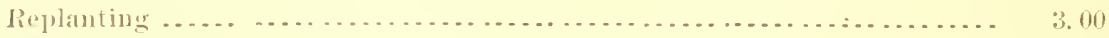

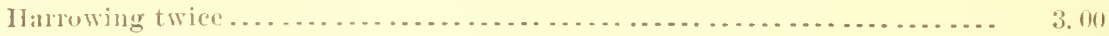

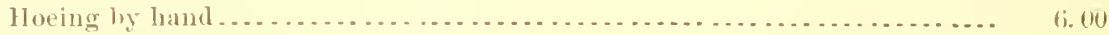

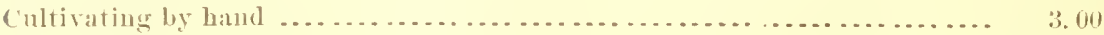

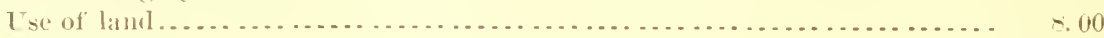

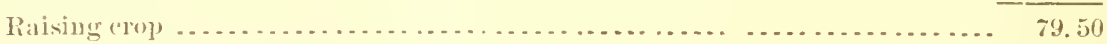

Cutting and storing in silo.................................... 47.75

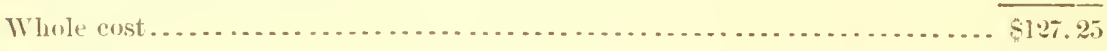

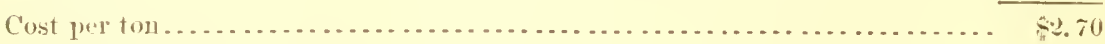

1\%. six weeks.

16. Ahont 2 inches on top was moldy ; below this was very natural in appearance, slightly warm and a tritle aeid.

19. The warmtl disapleared, and it grew a trifle more acid for about six weeks; after this I conld sece so changes. 
20. 'Three tons of ensilage equals one tou of' best English hay.

21. froorl.

22. I have had no experience, except with horned cattle and pigs. It is of small value for pigs.

2:3. 60 ponuls of ensilage, with 6 pounds of grain for an arerage-sized cow per tay.

24. Fom the loth of November to the 10th of Jamary, I fed 45 pommes of ensilage and 5 poumls of hay; from the 10th of Jamiary to the 10 th of Mareh, 60 pumuls of

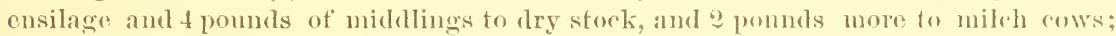
from the 10th of Mareh until May 1.60 pounds of ensilare, one fodleriug of oat straw, and 6 pounds of grain to cows in milk.

25. Good, both in wright and health.

26. Very protitable, all things consileresl.

GEORGE II. Axws. Dracut, Mass.:

1. Comnected with barn, opposite cattle.

$3.30 \times 12$ leet, 14 fect deep.

4. 1s inches thick cementerl wall, one-third cement, two-thirds sand.

5. Ilay ind plank.

6. Stone 2 feet thick on plank.

7. 5.205 .

?. Com and oats.

9. l'ant by hand, grains 2 to 3 inches apart, in rows; cultivate twice.

10. Jnst as it leaves the milk period.

11. 20 to 30 tons: 30 toms a lare yiell.

12. Mammoth sweet eorn, and southern Dent.

13. Nearly one-half.

14. Cut one-half inch in lengtl. Horse-power. Cut:20 tons per day.

16. 75 cents to 81 for a fanner.

17. Six to eight werks.

18. Fermented, anel tart smell, nothing mpleasant.

19. Not any, if used daily.

20. About two-fifths the value of goml English liay.

21. Are better with hay and grain than without it.

22. About one-thind the value of Euglish hay,

2r. 40 to 50 pounds.

24. Hay and grain night and morning, ensilage at noon,

25. Fed alone, not as gool as English hay.

26. Consider corn a profitalole crop to raise for ensilage, and the best and eheapest way to enre it for winter use is to "nsilage it. Cattle liko it. It good corn meal, or good buglish hay, or ensilage, is given them at the same time, they prefer ensilage, then meal and hay. It takes the place of roots, and is raised much easier and cheaper. I think all New England farmess should haw silos, filled with good ensilage, for winter use,

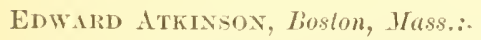

1. In root cellar, aljacent to teeding $100 m$.

3. Two, each $7 \times 6 \frac{1}{2} \times 8$ feet leep, curb 4 leet ahove the silo.

4. Stone three silles, one sicle brick, and partition of brick.

5. Two thicknesses of :-inch plank.

6. Stone in barrels, 1:20 pomits pier foot.

7. Cost abont siso, tont no eriterion for others.

E. Com and clover.

10. In tlower. 
14. Haud-entter.

17. Two moutlis.

18. Good.

19. Very little at edges of top.

20. A, No. 1.

21. Inerease in quantity, better quality.

24. With some meal aud rowen.

95. Excellent.

26. Saving of time, eost, and labor.

A. C. A trer, Lowell, Mass.:

1. Opposite cattle, iu bay of barn.

3. $36 \times 14 \times 12$ feet ileepl.

4. Twenty inches split stone, 4 inches cement.

5. Plank covere.

6. Twenty-tive toms of stone.

7. 8050 .

$\rightarrow$ Corn,

10. When the (arn is in blosiom.

11. Thirty tous.

12. Sonthern lent.

1:3. No сонираrison.

14. IIorse-puwer witl cutter, corn cut $\frac{a}{2}$ inch long.

1i. 55 cents to 81 jer ton.

17. 'Twents to twenty-five days.

18. l'rime condition.

19. No loss.

20. One half the price of English has.

21. Improves tlavor and color.

22. One half the price of English hay.

23. 60 pounls per hearl, per lay.

24. Good either way; for dairy results, prefer grain with ensilage.

25. Comclition as grood as those fed on English hay.

26. The cheapest tied for eattle. I do not believe New England farmers can eompete with their neighhors who feed ensilage, with ans other kind of feed, for either dairy cattle or young stock. There is no substitute for corn ensilage, for economy.

H. A. BarTow \& Soxs, I'ittefield, Mass.:

1. Three silos adjoining end of barn aud opening on a level with stahles.

3. Each $15 \times 10$ feet, 16 fret deep. Capracity of each silo 60 toms of green fodder.

4. Concrete walls, male of cement, gravel, and small stones; thickuess, 20 inches.

6. Stone, from 75 to 100 pounds per square foot.

7. Our three vilos cost $\$ 300$, . 100 each.

8. Rye, sweet 'orru, and rowen.

9. We sow 2 bnshels rye to the acre; after cutting the rye we plant the same ground witlı corn in rows.

10. Rye when just realy to bloom, corn in the milk. The sweet corn when taken ont to feed was as milky as when put in.

11. The amonnt of fodiler per acre depends upon the richuess and eultivation of the soil; from 20 to 30 tous per aere in Berkshire County wonll be a fair estimate. Rye, 9 tons to the acre.

12. Large evergreen sweet corn.

13. We have not planted any but sweet corn for the last teu years; we keep a dairy 
and are satisfied that swaet com for that purpose is very much the best. Wre have always ferl it with cars 01 the stalk when green. With the silo we have it all green allul un waste.

15. The folder should be ent and put into the silo as soon as possilhle after being cut in the field. Onr rye was cut with a reaper for $\$ 1$ per acre, with two men to hind, one man with team, and two wagons, and thee men at silo. We jut in 3is tous n twi dips and th: weiglits on, everything eomplete.

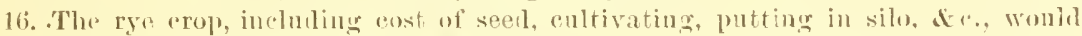
not pxereel, at high prices for lod!r, s1.25 per ton.

17. Alunt two months: lomere might be better.

18. Goorl condition; onr cows enjoy it.

19. Not any; goud until userl 11].

20. We prized it rery much; so dirl the eows.

21. We never had so goul a flow of milk in the winter'

22. All stock like it: we fexl it to poung storek, luorses, hogs, and ponltry.

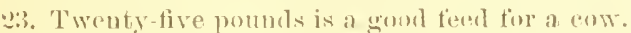

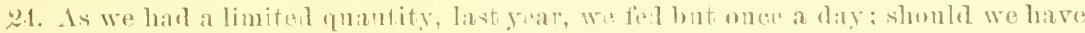

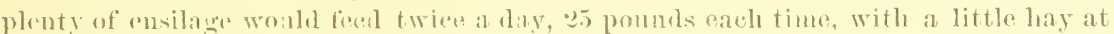

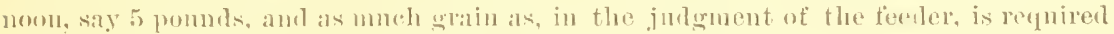
to put ou thesh or produen a hetter anality of milk for butter.

25. All in a healthy coudition; young stock will thrive on ensilage withont any griaill.

2h. We have resorted to root "rops for the last five gears; we liked them rery much, but ensilage is better: it does not cost near as much iu labor and fertilizers, and gives hetter results.

\section{R. BARKER, Lmeell, Mass.:}

1. Adjoining feeding-rooms; top on same level as floor.

3. Two silos, $22 \times 11$ fret, 12 feet deep, and one sito $22 \times 15$ fert, 12 fret deep.

4. Conerete, four parts sant, 1 part cement: walls 1 inches thick, corners rounded.

5. IIay, or straw, 1 foot thick, a covering of sheathing paper ou top of hay, and 2-ineli plank laid on that.

6. 25 tons to each silo, (200 ponuds per sinare foot), either stone or grain, laid evenly over the surface. If stome, one foot thick.

7. Three silos eost s600.

$\therefore$. Corn, oats, rye, elwver, and meadow-grass.

9. Corn, in drills, $3 \frac{1}{2}$ feet apart-three pecis to the acre.

10. Cut when in bloom.

11. Corn, 30 tons per acre; rye and oats, 6 to 8 tous.

12. Have nsed sonthern white, and Stowell's erergreen sweet.

13. Cousider the sweet corn more valuable than field varieties.

14. Fodder is eut in pieces $\frac{7}{8}$ inch loug. Cutter driven by a 4-horse-power engine.

15. As the silo is being fillod, the fodker is well trodilen.

16. $\$ 1.90$

17. Four to six weeks.

18. Green, with aleoholic odor; noloss on sides, and not more thau half an inch ou top.

$: 0$. Corn and oat ensilage more valuable than any other feed nsed, with the excep tion of grain, for mileh eows.

21. Makes more milk aud better butter than any dry feed.

2.2. Valuable for hows ami fowls; have not usc'il it for horses.

2:3. 45 pounds per das, for eows.

24. Fed with shorts, 6 guarts pur day, and from 1 to 3 quarts per day of corn meal, together with 8 pounds of hay.

25. Stock in good condition, with a gain in weight, and good health. 
26. More profitable than any fued used. Mr experience has been most satisfictory with all the grasses except neadow, which I do not cousicter worth nsing.

\section{Fren. Bartetet, Shrevsbury. Mass.:}

1. Silo 1: feet from baru.

3. $12 \times 20 \times 12$ feet deep; li teet below and 6 feet above gromur.

4. Concrete, 12 inclies thiek.

5. Jay, 3 inches thick, and planks.

6. Stones, $z 00$ pombls to the square yard: shall put on 300 pom th the coming season.

\%. -160

$\therefore$ stomell's evergren sweet corn.

10. As soon as it commences fo silk out, hut I inu not quite sure; it may be as valuable when the corn is in milk.

11. 10 tons.

1:. I have planted somthern corn this year.

13. There seems to be nore acil in sweet corn ensilage than in ensilage of laterer corn.

14, 15. If conn was cut hy two nem in the forld, whe laicl it in little bunches so it conld be handed to the tuanster who was loading, while the ofler tram was at the silo muloaling. I sed stran- power tor cntting: two men in silo leveling aurl treatiner.

[6. It cost fis couts per tou to put my com into the silo.

17. Thres: montlis.

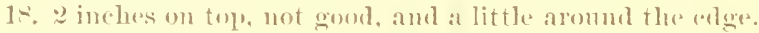

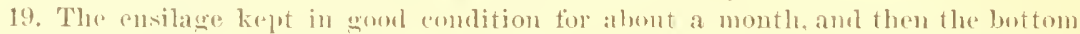

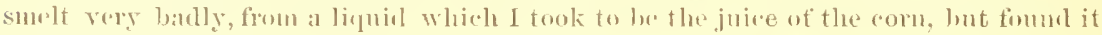
to be water which had lakked in. 1 lost 4 or i fons in this way.

201. Tiry gooil.

21. The milk was rich as Jume milk.

y.). Ferl some ensilage to my horses, lnt do not think mund of it for them.

2.:. From :30 to 60 pouruls.

24. Fenerally, :20 pounds of ensilage, 2 quats of cottonsinel meal, and what luay they wanterl.

2.7. Iy stock look as wrll as ever they did: henlthy and in good condition.

26. All things consielered, there is protit in encilate for the farmer.

\section{B. Beale, Torfolk, ra..}

1. Silo:3u yarks distant from tieding room.

$3.20 x: 30$ fiet, 12 fert deete.

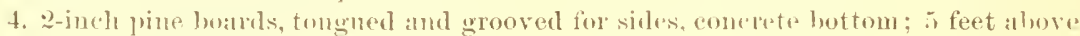
groumd and 7 foet below.

5. 2-inch pinr boarls, two thickursses.

6. Stones.

7. 'Total cost of roof, silo, and drainage, aluot siou.

8. ('or).

9. Rows 4 feet apart, stalks timu 6 to 9 inclues in the trill; gare if two harrowings and one plowing.

10. Cut my corn just as it passied the roasting-and state.

11. Not execeding 15tons pere alere.

12. Userl commons sonthern white ilint.

14. Cut firom to to 4 inclues long.

15. Did not fill numo than twa tiect per das.

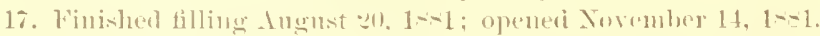

1-. I put about? feet of millet, wather ripe, on my foclerer. The millet was mombly

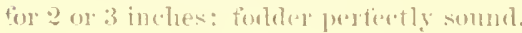


19. At first I only removed ahout' 5 feet of the eovering, and eut ont the ensilage to the bottom. The edges began to deeay; I then removed whole of eovering and fed from the top, and experienced no further trouble.

20. I estimate that I saved about one-thirl of the eost of feeding, compared with thw olel way.

21. The tlow of milk was fully equal to the best winter fecting, and the r.xpense muth less.

24. Fed always in connection with other foed, mixing with ship-stuff, corn-hran, and com-meal, moming and night, and giving a gool feed of lay at noon. This $\mathbb{I}$ regirul alsolutely necessary to obtain the greatest sncess, hoth as to quantity of milk and condition of cows.

26. I believe it to be both eheaper and more profitalule than our olel style of winter feeding. The best results eame from ferding in comnetim with peannt vines that hat a great many peamuts on them. I obtained more milk aud of better quality than when I fed corn-meal auk ship-stuft.

\section{E. P. Binzenct, Wew Fork City, Ir. Y.:}

1. Silo 10 feet helow and "' feet ahove gromul, arljoining cattle-shed.

$3.2: 3 \times 12$ fert, 12 feet ileep.

4. Walls of briek, 12 inches thick, laid in cement; hottom one layer of brick ani 2 inclus cement over.

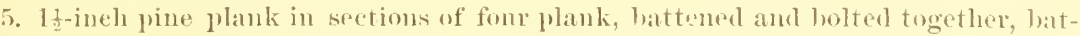
teus extending out $2 \frac{1}{3}$ inclies to make all settle evenly.

(i. Weighted with so barrels vinegar, of whieh we had a linge enatutity convenient in same building; alunt so promuls to square foot.

7. Cust of brick, cement, lime, and labor, s.55. Mbont s75 of above anomnt was fol' labor in exeavating aud removing airt.

8. Corn.

9. Rows 3 feet 3 inches apart, and thinned out to sinches in row; manured in row, and cultivated twice.

10. When ears are in silk, but not so far advaneed as to have the grain formed on the eob.

11. Sixteen tous to acre, estimaterl.

12. Have not experimented with different varietirs; am satisfied to plant same kind as last year, viz. sonthern white.

14. Cut in 1.ineh lengths.

15. Cutter stands on wall of silo, so that fodder as eut falls directly into silo; cutter run by sweep horse-power; same that we nse for cider-nill.

16. No estimate, but about same labor as in cutting up and husking of mature corn per acre.

17. Two months.

18. Somewhat faded in color, slightly vinous in smell, and acid in taste; juicy; no moult or decay.

19. The last section was fed out ahont 25 th of April, and seemed to have improved with age.

20,21 . We fed but two milch cows; both increased materially in flow of milk when we began feeding ensilage, and continned milking well throngh the winter.

23. Kept 110 accomt of weight, but ferl thrm all they wanted.

24. We fed to our young stoek ensilage amt ily stalks; to mileh cows, ensilage and bran; and to one bull, ensilage alone.

25. Onr stock never winteren hefter; young stock came out this spring in goon flesh and remarkably snooth-coated; cows came in saffely, with a better flow of milk than in former years. On Holstein bull, "Lorl Nelson," was ferl from December 1 to Fel,ruary 11, exelnsively on ensilage. He gained in weight from $1,3 \times 5$ to 1,445 pounds. 2 SIL 
26. Can only auswer ly comparison. We consider one acte of corn-eusilage equal to 4 acres of husket eorn and stalks for feeding young stek and wintering dry cows, (we are not dairgmen and cannot say as to nilk pouluetion). The cost of making corn-ensilage per acre would not differ materially liom the cost per acre of wrowing and husking corn, gathering stalks, aut housing the same.

Renalks.-Although in mo tirst year's experience with ensilage we lave failed to realize the wonderful results of foffart, Bailey, and other writers on the sulyect, we have also failed to fiud one siugle valid objection to the silo as an economical muas of preserving tidder, or to ensilage itself as lond for cattle. We intend this season to make a tew uiuor alterations in on plaus and mothols. We will plant very much thicker in the rows, so as to hare a greater proportion of leat to stalk, and will not allow the eorn to matmre as much as we did last season. We inteud to adh rely matterially to the weight, increasing it to 150 pommls to the spuale foot. We will contiume to nse baruels for wrighting the silo, as we think them hy far casier to move and handle than anything else of sime wright. We are now filling a lot of eondemned cieler barrels with saml, to put on mur silo, end np, as first layer, aml then roll on top of them a lajer of aieler or vinegar. We propose to use an additional eover mate of 1 -inchspruese boarls, to lo put on wh"n the silu is liall full, and then till tlee silo on top of this. The olject of this is, that when we leerl ont we will only expose to the ail a wall of ensilage six feet in height. As the "nsilage is fert ont fom the top section the batrels will be howed down to second cover, thus continuing the wight.

\section{W. B. Bexsax, Cardinal, Cunada:}

1. Adjacent to and eonneeted with teenling roms.

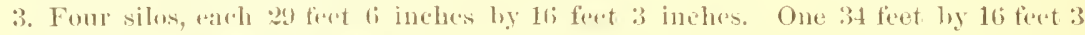
inches; depthe tent is inches.

4. Stone wall, with montal of samb, and water lime, 12 tiect s inches high, donble

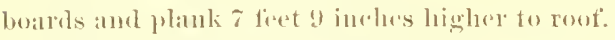

5. Plank 16 teret long, 2 inehes thick, crosserl with short pioces 4 feet long, so that we can uneover 4 fint at once.

6. Loose stones of a convenient size for handling, to the lepth of alout 2 fext,

$\rightarrow$ Corna and sorghnum.

9. 3 feet apart, harrowed sereral times, and enltivated as lone as a horse can walli between the lows.

11. Alome 15 toms.

14. Cut corn alont halt an inch long. Used stean power.

15. Took abont three days to fill each silo, having men and bogs spreaching and treading it.

16. Cost too mueh, probalily sl per ton. Hope to manage better this year.

18. Abont s inches of it damaged urar the top. (but the sherely ate a good part of it), and about 4 inches next the boinds, alowe the stone work, was not very gool, but the rest was highly relisher by the stock.

19. Cut down about 4 fret in wilth at a time, going from top to bottom, leaving the plank and stomes on tho rest. No pereptible deterioration.

20. Prefer it to anything I have yet triesl.

21. Cond not drect any particular taste, cither in the milk or butter.

22. The steers that I fattened put on tlesh rapidly, as the ensilage seemed to prevent them from getting feverish. The thoroughbred stock also liked it well, and their eoats hambleel well.

23. The milch cows gat almut 50 pomals per day, the steers 40 pomds, and the

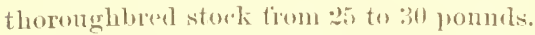

24. Fed the mileh cows with mat straw part ot the bine once, and part of the time twice a day, giving them lots of it, amd bedding them with wiat is lelt. Mixed bran and cotton-seed meal with the ensilage. The fattemuing eattle had a little lay, but preferred the ensilage mixed with grounel oats, eotton-secd meal, and bran. 
25. Most satislinetory in all resperets.

36. Au so well pleased with it that this year I have planted sl areses of corn, and

l hope to mix some elover with a pare of it; as I pret it into the silo.

\section{INo. P. BExt, Maynard, I/tess.:}

1. l'he silo joins the billu, with a door opening into the feeding room. Alout lualf the dinth of the silo is helow the floor of the feeding room.

3. $40 \times 16 \times 17$ fect deriple.

4. 9 feet of the walls are stone eenented on the inside, and the prinaining 8 feet concrete and stones. Onc sitte is a bank wall, the ground boing grandid to the top.

5. $1 \frac{1}{2}$-intel plank.

1i. Stones, about 1 foot in droptlo.

7. St75, inclusling the lutiluling above silo.

$\therefore$. Corn.

11. Whan in full hlosson.

11. 20 toms to the acre.

1:, I:). I think I ean raise twier as many toms of sonthern white as of swet corn.

14. It was cut into pieees alunt of of an inch long, nsing stean power.

11i. SI.:.5.

17. 60 liays.

1.-, 19. It kiplt wall.

201. I think 2 tous of eusilage repual in value to 1 ton of stock hay.

2. 'The milk is as good as when the cows are fed on has.

2.?. Eymally as gowl tor othre stock as for mileh eows.

:2:. About 40 pounds per day.

24. 'They lad one fodflering of" hay per day, with brewer's grains.

25. My stwek look as well, and are in as good health as they lave been for twenty years.

26. If I had not a silo now I would build one as soon as possible.

\section{OTis Busme, Poughtielepie. N. I. :}

1. The top of the silo is rven with a platean, the bank desemuling 50 feet to the stalle, and very steep. The ensilage is taken ont by a hoisting apparatus over the top of the stone wall, and carried in a cal on a gently descending grarle into a small lowse, built on the roof of the stable, where the botton falls ont, and the ensilage drops to the Hoor over the stable.

3. Double; $\{$ and - feet wirle, respectively, by $24 \times 15$ feet reelu.

4. Stone. Ontside walls dry, 30 inches thick at the bottom, and 20 at the top. Division wall 20 inches, laid in eement, and all walls plastered with cement. The walls were huilt by masons, in accorlance with their notions of fitness, with the result of an extravagant cost. Alove the silo walls is a curly of matched boaris, 6 feet high for settling room-of conrse, a rool covers the whole.

5. Hemlock plaulis.

6. Stone, 14 inches thick and earth banked at ends of plank.

7. listween siono aud š-00.

9. Plant in drills 30 iuches apast ; harrow when smatl, and afterwards lieep the eromel stired with enltivator.

10. I cut when the hlossom apperared on the tassel. I fomnd in the hottom of both silos a large cuantity of the juice, which I was obliged to hale out. On this accomnt I think I shall hereafter lot the cro] go farther towarls maturity.

11. Last year I phanted in drills 4 feet apart, and got about 14 tons per acre. This year I am planting much thieker. It appears to me that the maximm erop cannot he wuch greater than 30 toms per acre. Several stalks of uy last year's erop weighed

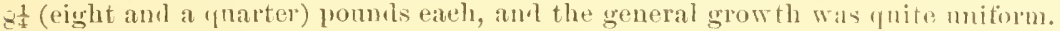


12. I plant the southern horsetooth variety.

14. The longer bits of stalks are the ones not eaten, if any part is left. Inferenceit is best to ent the stalks into short pieces. We eut of an inch.

15. The com from the field is cut on the upper grade, and descends into the silo till the top is reached, when the enrb is filled with the shovel. It is expedient, when nearly full, to alternite, so as to give time to settle. A eovering of six inches will control the surfuer leat. When lacking we trear it all we cam, but depend more on the natural settling.

16 Com, se perton. Draw it $1 \frac{1}{2}$ miles.

17. Thirty-three lays.

Is. spoiled 2 inelus sleep firm top.

19. Exposure to air destrys the surface-slowly in cold weather, more rapidy iu warm.

201. An now, Jnus 3oth, tionling eorn ensilage to fonr enws, and it is the mly forlder fed except grain. ('ows that ate nothing lut misiage through $A_{\text {pril }}$ and May are in the timest andition.

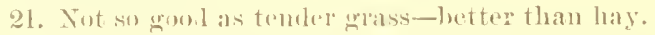

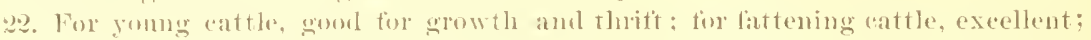
firr some lorses gowd, and tior ot laers not gool.

24. Corn meal and wlyat han, exual parts by weight, or sommthing equivalent, slomlel supplement the phsilage.

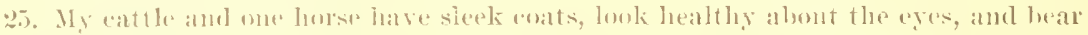

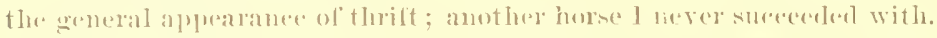

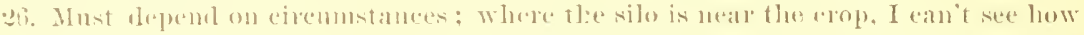

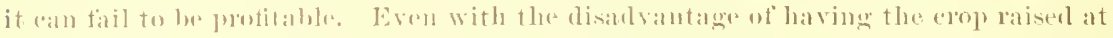

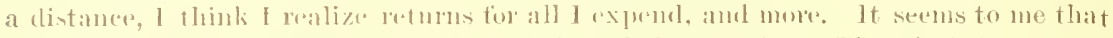
chemieal analysis reaches only a part of the whole guestim. The vital forces concerned in ligestien are more impertant. A mere long seres the commection existing between thash, temler patsturage, and full pails of milk. Tell the bey that the tomder

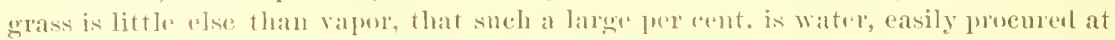
the brook, that sneh a small pere eent. is atsh, that the prorts that go to make fat and muscle and hotter, alter the water is removed, are an insignitieant amonot, and he may stare and womder at your learning, lut you will tail to convince him that the dried grass is letter for milk than the fresh grass in the pasture. Let me add that a young chilu fed on the milk of an ensilage-frol cow has no irregnlarity of the bowels, is good natured, aud grows finely.

\section{Bookstaver, Syracuse, I. Y.:}

1. On level with feeting room, in rear of stable.

3. Two, each $70 \times 16$ feet, (depth not stated).

4. Stone walls, smoothed with cement.

5. Plank, well fitted.

6. Bowlier's, 500 pounds per square foot.

7. Alyont

8. Corn.

9. Sowed in drills-ordinary enltivation.

10. When the corn is in the silk, before the kernels glaze.

11. About 25 tons.

12. Mammoth sweet corn.

13. I prefer the sweet, as it is rieher food.

14. Cint 圣inch long.

15. Fodler drops directly into silo-sprean and tramped by men and horses.

16. 68 cents a ton.

1є. Capital order; smelled sweet; eattle ate it ravenonsly. 
19. No deterioration after opening.

20. Two toms of emsilage expal to a ton of good timothy laty.

21. It eansed an increase of milk, from 1 to 3 quarts, after three days feching.

22. Equally grood tor horses, eolts, slieep, de.

23. About 60 pounds a day.

24. I prefer to feed dry corn, or harley meal, or linseed neal, with it; it does well withont this by fereding lay onee a day.

25. Perfect hralth, bright ejes, smooth coats, and soft slims.

26. The most profitable food ever usal. I made smo exprerinents last winter in feoling a heifor, cow, mare with foal, wonlibig colt, and an old trotting lorse. Cut timothy and elover liay, mixed in a large box with an equal amomt of misilage, adoling a little corn meal, costse hran, and shorts, and allowing the foed for the morning to remain over night, and again preparing in the moming for night. All were wild for their feed, and never left a spoonfinl to waste. A colt of the same age of nine, larger, and by many considered the best of the two, was ferl from the tine of taking up, in the old way, with lay given whole, aud oats. 'This spuing my eolt looked like a two-vear-old eomparal with the other, and at a less oust. The cow and heifer did copully as well. The oll horse cance ont looking like a colt-lis roat was never so fine as now, and the mare with foal never dirl half sin well before.

\section{H. E. Inswre, Thetford Centre, Гt.}

1. Door opens to fexling room. Tottom of silo 4 teet below basement.

3. $13 \times 1$ - feet, 11 feet deep.

4. Stone, pointed with cement; shall continne with wood to upper beams of barn.

5. I'lank, :2 inches thick.

6. I)id not weiglit, owing to pressure of business.

¿. Corn and clover.

9. Drills 3 fuet 4 inches; eultivated but little.

11. 20 to 25 toms on land not mamured.

14. Cut some $\frac{1}{8}$ inell, some $\frac{8}{4}$ inch. Ised one-horse power.

17. Two moutlis.

1.. Good; to my surprise only 3 or 4 inches of top damaged.

19. Vers little.

:11. Two tous better than one tou of good hay.

21. Especially goor.

23. Being short of ensilage, only for 30 punnds per head pridas, with hay or grain.

21. Ftalks or hay at $1100 n$.

25. Stock did well erery way.

26. Deeieledly profitable.

\section{J. B. Blowx, 55 Beckmen street, Tew Tork City.:}

The following answers are the sum of praetical experience, collected from examination of many silos:

1. l'referably on sloping ground, so that the discharge door may be on level with feeding room, anc so that a ear may be used from silo to manger.

?. Oblong or elliptie, but not important.

3. Inmaterial, but ceonony in deptl.

4. Conerete is better than stone, which is lialyle to be damp; wooden walls alove gromud snfticirntly strong to bear pressure, not necessarily air tight, aud do not need to be double, or lined; earth pits, well surface-drainerl, are in some soils as good as is necessary.

5. Immaterial, so that there be continuous pressure on the whole.

6. Whatever is cheapest; cord-wookl. sacks of earth or grain, harrels of earth, casks of water, or stone. 
7. From 20 cents to 61 per ton of coutents. Cheap silos preserve als well as expensive ones; it is only a duestion of durahility.

8. Naize and grass fir cattle; also rye, wats, and peas for horses and sheep, even Canada thistles and salt mearlow grass.

9. Com, in donlule rows, space 2 or 3 feet : space betwern kernels in rows not yet settlert.

10. Not, as the Fremele arvise, in the flowering, but to lave the sweetest and greatest nutrinent when the finit is in the milk; this is a point of great impoltance; must he careful to anticipate any farling of the leaves.

11. S6 tons of maize have been raised on an aces 100 toms may Ju rased on an acre ;

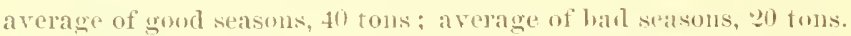

1:. Fouthern seed produces much the larger crops, and the more tropical the greater the growtlis.

1:. Sweet corn, having lowen enltivaterl for the grain, is not best for ensilage, as the stalk is not large enongh.

14. Thuee-pighths to three-fourths ineh is best length to cut, and as licenly as possible, wot sherded or nuasleed as is best for dry stalks. Cntting-machines should not bo liable to injury from stomes, and the revolving appiratus shonld not tmin towaris operator; elevators or curriers may be nsed to convey ent stallis to silo, and nucut stalks to feel ruller's of machine, if it is important to economize labor.

15. Not important to be in a hury when filling silo, exe'pt to save cost ; if trampled every morning it will not loat sufheiently to injure it, even if the prosess of filling consinme a montl, witlı intervals of days.

16. Thirty-six conts per ton is the lowest enst as yet hy hired labor: in this ease the silo was convenient to the crop, and the maehinery was powerful and efiteient-strong engine and large entter, with high sperd.

17. Two montlis at least; the longer the better.

15. Always good when the erop is good, and when it dows not get wet in the silo by leakage ; the silo improves tho puality of the material by inereasing its tigestibility.

19. Does not reterionte if the face is elanged every day or two; 24 homs' exposire diminishes acjelity.

20. Nothing so good as grod ensilage.

21. Inproves color of hutter, increases quantity and richness of milk, where ensilage is good.

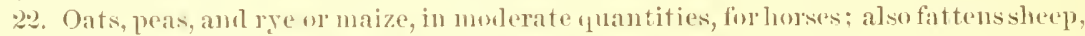
and is economical for hous, steers, and Julls.

2:3. 95 to 75 pommls per lay, or is pre cent. of weight of animal; for horses $2 \frac{1}{2}$ per cent. is sulfieient.

25. Good emsilage in proper yountities and raned with dry food at times makes healthy, thrifty animals: it must not be ton somr; animals will fatten on it alone that anumot be liattened with hay or dry stallis alome.

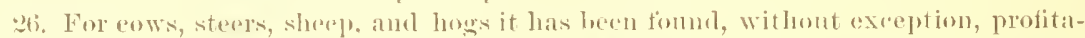
ble: New Eneland cannot do withont it. It is a profection frum drought in Debraska and rlsewhere; it is a satity from lire, grasslepplers, and worms, and, more than all, is valuale in Texas.

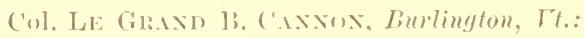

1. On the same level.

3. $14 \mathrm{x}$ 45 fert, 15 fuet deep, divider Jey a wouden partition.

4. Stone, 10 feet: worl, 1 feect.

․ Abont stio.

-. Corm.

9. I'lanted in drills, and enltivated three times, the land being well mannred.

10. Ifter the grain has formol on the ear.

11. By actual weight I harvestal on 3 ateres 23 tons to the acre; and on 10 other 
acres ahont 12 toms to the acre. I think a fair average crop would be 15, tons fo the acre.

15. The harvesting, chopjoing, and filling. should be done as rapirlly as possible. If convenient the silo slomld he tillud, coverou, and weighted in two days.

16. Assuming sis per acere for mantw, \$15 per acre for planting and enltivating, with a crop of 15 tons to the acre, 75 eents per ton for entting, drawing, and packing, ensilage would cost \$2.75 per ton.

17. Six weelis.

15. Temperatme on opening, alhont 90 . Conclition apparently perfect; formentation vimons, and alplarently stopjere at that point.

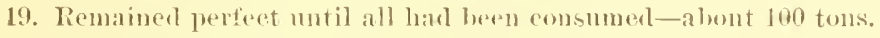

2.2. More than the equal of hay, emsidering the eost of each.

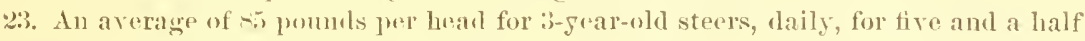
nonths.

24. Witlı thre ponnds of grain daily.

25. Cattle fed as stated in $2: 3$ and 24 made a greater gain and were in better health and condition than uthers fed on :0 ponuds of chopped hay and 3 pomuds of wrain.

26. I consider ensilage profitable, and believe it is entirely liealthy, taking the place of roots. It is easily digested, as is shown hy the uniform temperature of the animals and the condition of the skin and hair.

OBsER VATUNS.-The claims made by many writers in regard to ensilage are extravagant; that it las certain alvantages cannot be denied.

First. Not more than 15 to 25 tons can be depended upon per acre.

Second. It is more certain as a crop than has.

Thirl. Twice as uany aniuals can be kejt on the same acreage.

Fourth. It is largely a sulstitute for roots.

Fifth. The labor of freding ensilage is nuch less than hay.

Sixth. The space required to store ensilage is not one-quarter that required for has.

Expermext. - I fud 90 three-year-old steers, divided in three lots; cattle and feed weigled monthly.

First lot. Fed 20 pommds hay with thee poumds grain daily; rm in yard with shelter.

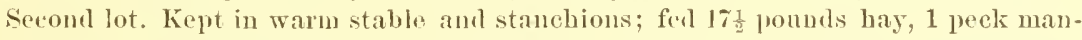
golds, and 3 ponnds graiu.

Third lot. Fed 85 pounds ensilage with 3 ponnds grain; this lot gained one-quarter pound a day more than No. 2, and one-half ponnd more than lot No. 1. The cost is per cent. in faror of ensilage.

\section{Janes S. Chaplet, Wassaie, N. T.:}

1. By the sidle of and parallul with barn, and so arrangerl that the ensilage comes from the silo to the flow directly wer the animals to be terl-the barn being built against a siole hill, and the silo placed on the ulper sisle.

3. $50 \frac{1}{2} \times 1: \frac{1}{2}$ feet, 16 feet lee 1 .

4. Comerete, of liycraulic cement. gravel, and cobblestones.

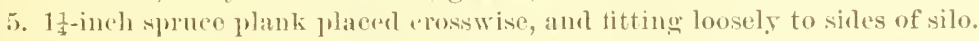

6. Stone, 75 pounds to siguare foot.

7. \$.30, iucluding roof.

6. Corn.

9. 1)rills, 3 feet apart.

10. Whin fully tasseled, and before any of the juices dry up or are gone for the formation of the ear.

11. I have produced from 16 to 30 tons of green corn per acre; should call 20 tous all average yicle.

12. Blount's l'rolifie best: White fouthern next.

14. Cut oue-half inch in length: entter driven hy a five-horse steam engine. 
15. Distribute the ensilage evenly in the silo, and pack as thoroughly as possible, putting in from 25 to 30 tous per day. After it is full put on a few incles of straw and place the planks.

16. 80 cents per ton.

1\%. Two months.

18. The ensilage loses its green color, lunt retains form and consisteney, with no appreciable loss of moisture; luas a slightly acid taste and alcoholic smell, with sometimes a rery small loss at top from mond and deeay.

19. None.

20. It effects a saving of grain aud forage, and eows thrive hetter.

21. The milk is richer and much pheasanter to the taste-moro like that produced from pasture than from hay and griain.

203. 5o pommls per day to pach cow.

24. sometines alone, hut usmally in counection with hay and grain.

95. A lecilud gain in flesh, "lpetite bettr, hair sleck and glossy, and eyes briglit. The excellent combition of my stock has attracted the attention and almiration of numberless ensilage visitors.

36. The profitalbluess of ensilage lies mainly in the fart that it can be male to double the stoek-carying capacify of our Eastern farms, aucl that too at a very small comparative cost. Its alvautages to the sale-milk lairyunen ane incalculable, and I see no reason why they shomld he less to butter and eheese proluers. Dairy farmers who lave used silos two years have alvealy athed 50 pere cent. to their former stock.

Vetor Chise, ballourille, ronn.:

1. In end of stable.

3. $10 \times 14,10$ feet alcell: 8 fint malergromul.

4. stonc.

5. Plank, matrled.

6. Two cords of stone.

7. .50 .

c. Conll.

9. Planted in rills.

13. Sweet coln is bist.

14. Two-horse trearl-power.

16. Fonr men, and two hoys, with horses, in onte and a half days filled the silo and put the stone on.

17. Two montlis.

1E. It was of a brown color, with a lintle acid taste.

19. Color chauged to a green after heing exposed to the air a fiew hours.

21. One-quarter more milk from ensilage than from hay. Good butter, well colored.

23. Two bishels atach.

24. Two charts shorts and one of cormmeal.

25. Coss cane ont well. Sold three for bet in the spring.

26. It will pay; I have three times as much this year.

\section{George L. Clemexce, Southbridge, Mass.:}

1. In basement of barn, rising 4 feet ahove floor of cattle stalls.

3. $40 \times 15 \times 17$ fect deep: aivided into three compraments, each 15 feet long and 12 feet wide.

4. Walls and floor comerete.

5. One-and-a-lalf-inclı plank, fitting closely.

6. Cohblestones to a deptl of 18 inehes.

7. 400 . 
8. Rye, corn, and clover.

9. Corn planted in drills 3 feet apart, $3 \frac{1}{2}$ peeks per acre, kernels abont 4 inches apart in the drill, enltivated with smoothing harrow at intervals of four or tive days, and once with a horse-hoe.

10. When in fill bloom.

1I. Rye, 10 tons; clover, 8 tous: eorn, 2.5 tons. Owing to severe drought the corm did not attain the grow th it would in a more farorable season.

12. White Sonthern corn.

13. On account of the immense size of the ahove-named variety, I consider it worth at least one-thirl more than any of onr variety of sweet eorn.

14. I consider it of importance that the crop to be ensilaged shonld be free from dampress, as too much dew or rain will canse putrefaction. Cut into $\frac{8}{3}$ inch length; cutter driven by a one-horse sweep power. I let elover wilt one day then put into the silo withont being run throngh the entting machine.

15. The lahor of filling my silos is performed by four men aud three lowses. One man cuts the st:tuding erop, anotlee man with two horses loads and carts the fodder tor the barn, one man feeds it to the cutter, while the fourth man is in the silo treading it down.

16. Careful aceonnts of the cost of ensilaging my corn and rye make the average 40 cents perton; elover, not heing ent into short lengths, cost 25 cents per ton.

17. Depends on the condition of my pastures and the lateness of the season.

15. There is a change in the color, yet even this is often very slight; as to ferding 'qualities, I can perceive no loss.

19. I kerp all but one section of the ensilage covered; there is no perecptible loss.

20. I have never kuown it to fail to inerease the thow of milk over dry hay of the best quality.

21. As a natural consequence it imparts a taste to the milk and loutter analogous to that produced by the green grass of onr pastures. The milk and hutter have more body and are richer aud hetter than from the best of English hay.

2:. I cannot sperak in too high praise of its excellence as foot for young stock, ponltry, and swine.

23. I fed 70 pounds per day to an ordinary sized cow.

24. My pratice is to feed immediately after the morning milking, 25 pounds corn ensilage and one ruart cotton-seed meal; second foddering, 4 pound of Euglisl hay ; third forldering ( $12 \mathrm{~m}$.), 20 pounds of elover or rye ensilage; fourth forltering, 4 pounds English hay; fifth fordering (directly after milking), 25 pounds corn ensilage and 1 quart eornumeal.

25. Withont exception my stock thrived on ensilage. It gives a vigor and healthy appearance not seen in hay-fed eattle.

26. It enables us to make milk and butter in winter as well as in summer, and to keep our stock at one-half the expense of dry fodder. We can keep, on the same amount of cultivated land, a much larger stock of eattle, thus increasing onr supply of mamure and the fertility and valne of onr farms.

\section{A. R. Clevelaxis, Dalton, Hass.:}

1. Attached to eud of eow stible.

3. $30 \times 15$ feet, 16 feet deep; one-half above ground.

4. Coucrete, of eement and gravel.

5. Straw 6 inchesdeep ; planks $1 \frac{1}{2}$ inches thick.

6. Weighted with large stones 2 feet deep.

7. With the exception of my owu work and team, the cost was \$30?.75.

8. Corn and Hungarian grass.

10. When in bloom.

11. From 20 to 35 tons per acre. 
16. About 81 pere tom.

17. Twu months.

1-. The top was 6 inclues of 11 mgarias grass, 2 inches of which was a little monlly. The corn smelled sweet and gool : after standing twenty-four or forty-eight lunus, the orlor was similar to that of new bread.

19. It was all moovered, and heing exposed to the air, it smelled and tasted rather sonr at the last, hut the cattle always ate it with a relish.

21). I think 3 tous of cusilagr rqual in value to 1 tou of the best timothy hay.

21 . Aftror feeling ensilage me week my six cows gained 12 quarts in their milk per day: dis not gain any mole, but held thoir own. The milk and hutter were as grool as that obtained in June on good pasture.

2.:. Yomng cattle and shepl ate it with a relish, and in preference to good bay.

:3. 60 pommols per day to rach eow.

2.1. It was ferl at mon'ning and niglıt, 30 pounds at a feeling, with a small fodklering of liay at noon. I seldom forl it alone, nsing whrat midollings aud cormueal, half and lialt, 4 proats al day.

25. As 1 fed it, my stock improved in thesh and looks. loeing in poor condition when 1 commencel freding.

25. It enables one with a little land to keep a large amount of stock. Last gear I lumglit $\$ 1 \otimes 0$ worth of hay; this year I have wintered five more cattle on the same land and sold 8100 worth of hay.

\section{Cus Bros., Test Meriden, Comn.:}

3. Gur two silos are each $33 \times 14$ × 1 16 feet deep.

4. Walls 1s imches stome and mortar, lined with cement.

万. 1 foot straw, and boards.

6. 100 pounds stone per sifuare foot.

ร. $\$ 500$.

8. Have ensilorel corn, and grass corn and oow peas mixed, with erpal success.

9. Com sown with grain drill on sol, plowed immodiately after mowing. Cultivated witl smoothing harrow.

10. Wh'n the ear is in the milk, a earlier.

11. Largest yield (asmetained by weighing an arerage syuare roul), 16 tons per acre.

12. We liave planted the large sonthern White eorn.

11. Cut with reaper in fielel, and used water-power to cut it in one-thirel-inch pieces.

16. Estimate, sil per tom.

17. One to three nontlis.

1-. Always in good omiler.

19. No deterioration after opening.

211. Cows have thrivan exemelingly well, whether fiol with it alone or with grain. in about the quanity used when forling hay.

21. butter and nuilk from cows led npon it have the appearance and quality of the same marle from grass.

2.2. Sherp thrive. Have ferl to horses but once. Last fall we fed a mare and weanling enlt from the same ensilage that we feel to other stock. 'The colt dicel after there or four days, and the mare after five or six. Symptoms were inability to swallow, elewing foor and doppling it, holding month in water witlont drinking; and in the mares ase, excessive seoming. Tre attribute it to the ensilage, as our other horses, hay and grain fer, were porfectly healthy.

20. We estimated that am silos paid their cost the first yor, thongh only balf filled, notwithstanding loss of valuable blooded mare and colt. Wo have fonnd ensibage better fied for cows than elorer-has cht before hloom and "mow browned," which was the lest fodker that we had ever nsed before. 
P. 11. ConAxt, Smithland, Ky. :

1. Silo located in a sirle hill-was formerly used as a ristern. During fording season we hauled from silo to baru cellar and stable catch day's ford the night hefore nsing.

3. $1: 2 \times 1: 3 \times 10$ feet.

1. Stone crmented, :2 fent thick.

5. Two thicknesses of l-ineh plank, latu! so as to loreak joints.

(i. Rocks, $1 \frac{1}{2}$ leet deep over whole sulfice.

$\therefore$ Corn,

9. Drilled, ordiuary enltivation.

11. IIalf-grown forlder, anul ears in or just ont of the milk, mixed alunt half of wacli; cannot estimate value of either-was obliged to cut to salve it un aceomit of slunth.

12. Large white Sunthern.

14 and 15. ('nt in half inch picees. Having a grist mill mu by, steam jower wecut corn there, with ensilage cutter, and hauled to the silo.

17. 90 diags.

18. First class-except abont two inches aromul the outside and over the top.

1!). None at all.

2) Good.

21. Three funily eows tombled quantity of milk in two weeks; increase of crean in proportion to quantity of mills.

2.:. Equally qood for mules and horses.

24. Mixed ten per cent. of mill ofial-meal, bran, and shorts. Filled rack with good timothy hay. Stock ate ensilage in preference.

25. Comlition good.

26. Paid well. We believe stock can he kept for one-half the cost of any other feerl. and will fatten as mueh as during months of May or June on grass.

\section{Cimarles T. Cromwell, Rye, N.J.:}

1. I selectel a sicle hill for my first silo, and have a dor on the level yard whern the cows are fed.

3. $9 \times 15 \times 15$ feet deep; intended to store folder for func or five coms.

4. Both of my silos are built under gromul. Walls of stome, 1-inelus thick, lairl up and faced witl cement. Bottom, concrete. A blind drain extends aromn the sides.

5. 2-inch plank.

6. Sinehes of soil, but don't nse sand. Cattle and lorses like a little elean soil.

¿. The cost of my silos is uot a fair criterion for others who seek utility ouly. The silo I have just finished is huilt in the field where my cows pasture, for the purpuse of supplyiug them witl green forder in the months of July, Augnst, and part uf feptember, when the grass is dried up. This silo is $6 \times 8 \times 9$ feet dee]. This silu will cost

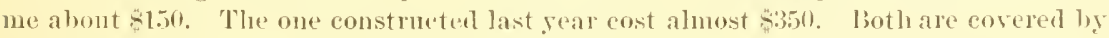
ornamental huildings, which add about half of the cost.

$\therefore$ Mrexperience leads me to beliere that everything of regetable natue that animals will eat, will make useful ensilage. For axample, last gear 1 cut up and packed

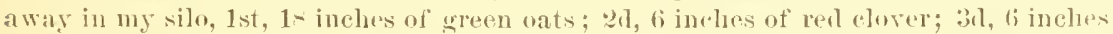

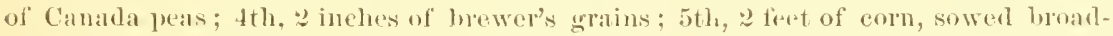
cast, more rag-werd than eoru in the elop ; bith, 5 inehes of eommon full-grom grass: 7th, a foot of sorghum; stlı, corn planted in drills. I spreal over every 6 or 9 inches a light sprinkling of salt, not so much to preserve the (misilage as to make it more palatable. The eattle aud horses ate all, including raw-weeds, greedily.

4. The more manure and the better the tilth, the greater the product. My prefor. enee is for drill-planting; I think it wise to sow coln in drills very thick. This gives a greater number of stalks, lut not so leavy and hig as thin planting.

10. Rive, oats, or corn should. I think, be put to the machine when the grains first begin to be in mills; then they are most sucenlent and nost nutritions. 
1:. The Mammoth Southern corn is best.

13. Not equal to the ahove.

14. My view is that the finer it is cut the more elosely will it pack, aurl it requires less mastication.

15. Treal it while filling, closely as possible, to keep ont the air. The ensilage after being in a day became quite warm, so it was nut pleasant to keep the hamb immersed in it. The warmtl is mly the emmencement of fermentation, is arrested as som as covered, and hoes mort good than harm.

17. Two nomtlis.

1.. Excellent, fresh and sweet: it had changed its color from green to a brownish hine.

10. The last of it momlded slightly on the surface, from want, I think, of keeping the silo shut. Wut ny cows ate it all; the mould didn't funetrate a halt inch into the 'msilagre.

20. One cow increased her milk from 3 ynarts to 7 , and was in good condition for the shambles all wiuter.

23. A cubic foot weh per lay.

24. My tustom was to cut out with a hay-knife, each day, enongh ensilage to feed the cows the next day ; shake it up so as to disintegrate it, amol mix a yuart of ban or

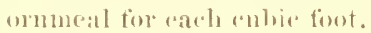

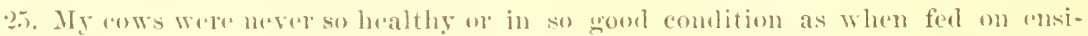
lage.

2ti. I look upon milage as of the ntminst importanee to the whole comntry.

1). L. W. Cerists, Southlridge, Matss. :

1. Shomld be so healed as to open into the stable where cattle ale ferl.

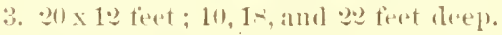

4. Sand. gravel, and cement, if ont of doors ; in a harn, fouble-hoarding with tarterl paper hetween, will do.

15. One and a half fiet derep of stone.

7. Huel depends npon how acessible the materials are. As I have sand, gravel, and stome near, it ruables me to buile rheaply. My thme silos, with capacity of :so toms, cost 8300 .

-. Corm, ryte, clover, IImugarian, oats, rowen, ant corn stover.

1. Sow rye in fall after taking off corn: and corn again in .Jum after entting the rye : cultivate corn with harrow and horse-boe.

10. Clover when just comine into blussom; rye jnst after healing; corn and Ilnugarian when in blosison; my rown I put in withomt cutting; 1 also piek my con just as it is glazed, ent thestorer and put into silo. It makes goud fodeler if carefinl not to let it dry.

11. In toms of corn to the acre, and on the same gromud 5 to 10 tons of ryo.

1.. Lare sontheru kinds.

14. Cut corn and rye three-quarters of an inch long-if longer, more pressure is re"pinired: I nse horse-power.

16. Fifty cents per ton will do it.

17. Four to six wecks.

18. Good; rowen ent when lew was off was very fiagrant.

19. If ted slowly it may become acid on top, nothing more.

20. Three tons are worth more than a ton of hay. Cattle eat it in preference to has, and give more milk.

21. Milk is better while feeting ensilage and cotton-seed moal than with hay and meal. The butter is like June butter.

2.). All stock like it, and with a little meal, luan, or hay they do better than on the bust of hay. J'hey do not have to mulergo the change from green to dry feed, am (lo nearly as well as at mastmre. 
2:3. 25 poumds per feed twiee a day.

24. Witli five ponuds of hay. When nearly done eating mix some bran wr meal with it, and they never leave any. Tho hay is given at night. A change is resira)]e.

25. Cows al ways gain muless in full flow of milk. Stock always does well.

26. Silos are profitable. 40 or 50 tous of fodner per acre mas be grown, which is worth mere than 15 tous of hay. I can cure my elover ambl have it as gool as when rint, and an not afraid of rain.

\section{W. A. IOHge, I'ost Mills, Ft:}

1. lloor opens into fircling room. Top even with harn floor.

3. $24 \times 10 \times 16$ feet deepr.

4. Walls of stome laid in cement \& feet loelow flour of basemert, and brick above.

‥ Plank:3 inches thick and s incless wirk.

6. Cobblestones, abont fiftern tons. We rolled them on, amb when wa wantal to remove them rigged a set of "falls," and lifted them with a horse in a short tinu.

\%.

- Cirn.

9. Planted with drills, at feet apant, enltivatel the same as for any corn crop.

10. Folder is the most valuable when it bexins to ear, or the ear is in the milk.

11. From 20 to 35 tons per aree.

12. I nsed the dent or horse-tooth.

13. siweet corn is better than common fiold varieties.

14. I'serl a one-horse power; cut $\frac{3}{5}$ inch.

15. l'ut in about 15 tons per lay. Kept it well trodden.

16. 50 cents pre ton to put into silo.

17. I weelks.

18. The straw and about 2 inches on top was damaged : the remainder in splumlid condition. My stock ate it as thongh it was so much meal.

19. None.

20. A mreat advantage to mileh cows.

21. No had effect on lintter.

22. Goorl for young stock.

23. 60 pounds to the head. Large cows take more and small ones less.

24. I fed ensilage and meal to milch eows, and ensilage to heifers and dry cows last sear, withont any other fodder; but I think it better to feed dry fodder once or twice a day.

25. My stock never looked better than when fed on ensilage. It lasted till the 1st of April ; after that stock fell off in tlesh.

26. All things considered, I am satisfied that it is the most profitable way of wintering stock in this part of the country.

\section{Wr. B. Eager, West Point, Nebr.:}

1. Our silos, four in number, requiring five side walls, are located about 1,60n feet from the barns, and ensilage is conveyed in wagons.

3. $40 \times 12$ feet, 19 feet deep each, inside measin rement.

4. Upriglıt pine timbers 12 inches wide, lined inside witl 2-inch plank; ontsicle with inch boards. Space filled with dry clay tamped solid. Floor, 2-inch plank, over 4 inches of broken brick.

5. $1 \frac{1}{2}$-inch plank.

6. Earth in boxes. We nse 35 tons to each siln, or alont 146 ponmls to a synare foot.

๘. The four cost complete, se, $400-$ all above ground, painterl.

s. Corn.

9. We have tried two methods, viz, in drills 3 feet 10 inches ap:alt, five to seren 
graius to each foot. Our other methou is similiar to the first, but we rum the planter hack between the two rows just planted, making the drils about 23 inches apart. We do not plow the groumd nutil we are ready to follow with the harrow, and this. with the plauter. As soom as planted we harow the gromm again to leve] track of planter, and when eorn is high enongh to see the rows, we again harow. This is all the rultivation we give to what we call the "donble drill," and is applicalble only to land free from werels. The "single drill" we treat precisely the same to the harrowing atter eorn is up, then kere the cultivator going mutil too large. We average. there cultivations. We are still in anbt which yields most.

11\%. When in blome, and hefore the ear is fully developed.

11. In $18-1$ the highest yiehd was of toms fienn one acre, lowest 10 ; arerage about

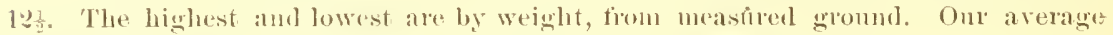
was much above $12 \frac{1}{2}$ tous upon all but - 0 areses of poor sandy lamb.

1\%. Wh have nsed only the westeru dent.

14. Cut in tield with reaprer; loaded by 3 men npon flat hay-rack. At silo, cutter ron liy a 10-lorse engine.

15. Requires 2 men to feed anter. and we man and 2 lads in silo to keep it level.

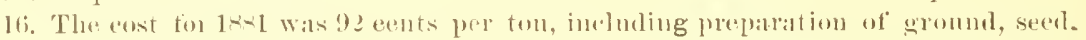

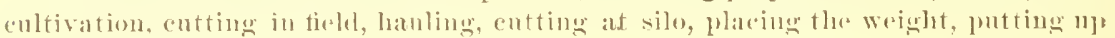
deors, forel, and housing angine.

17. 4 months.

1-. Goud, not one ponmilspoiled.

19. None whatever.

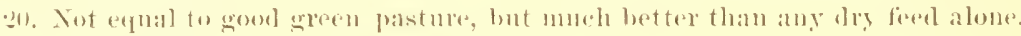

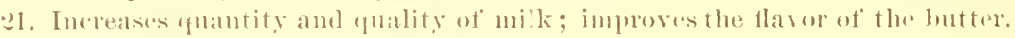

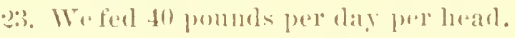

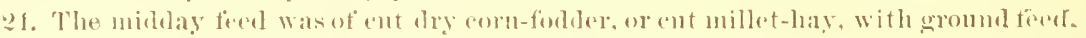

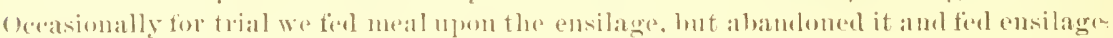

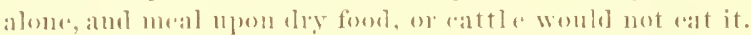

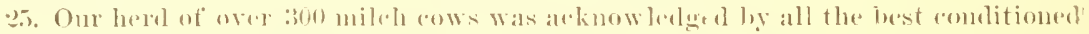

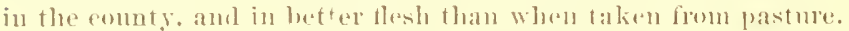

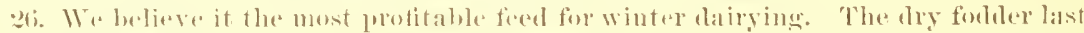
rear eost ns of. fo per ton (taking average as above to aere) in stouk in the fielel; and it had to be hambel to ham and ent afterwalds. To jut up prairie-hay cost us a.y cents per ton, ame it alone will not make milk, neither will it keep astlo fom losing ertatly thengh the winter. We tried feeding ensilane exelusively to one barn of $: 5$.

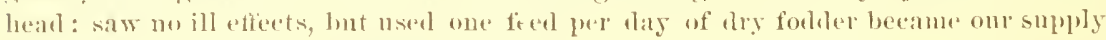
"astoo small for exclusive ferd to onl hert.

The abese answers for the West Point lintter and Cheese Association of this place, of which I am vice-president and manager.

\section{Jolix R. FAlixtu, Hulthum, Mass:}

$\because$ In a sterp lank, at the end of haru, and a spates lett open nearly to the hotions for taking ont the ousilage.

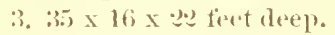

1. Fiell-stone, ponted with rement, and plastered.

b. Stone, as fiet de'pl).

7. Soil being bluc gravel the digging was quite expensive, making whole cost about $3 ., 0$.

- Corn and rowen- pincipally elover.

9. The ground was heavily mammed, and planted with early potatoes, 4 feet apart. After the potatees were hoed the serond time, about the :asth of June, the rorn was llanted between the rows with a phanter which distributes firtilizer at the some lime. When the corn was $1 \frac{1}{2}$ or 2 feet high, whe potatoes were lug and the corn hoed.

10. When the tassels begin to dry, and the ears are a little past the milk. 
11. The land I planted last gear was very dry. It produced 16 to 18 toms pere alere.

12. I planted 3 varieties last year; lave planted the Sonthern White this fear.

13. Not erpal to the ahove. I had la areseswet corm last gear.

14. Cut firom $\frac{3}{8}$ to $\frac{5}{x}$ inches. I sed stoinl-power.

15. Leveled by 3 or 4 men, and tomblen by a torse.

16. The whole aost of raising the corn and putting in was s. 1.49 per ton.

17. 2 nonths.

1.- The ensilage was bright, and the eattle ate it reallily.

19. I comld not see that there was any doteriolation of the ensilage in the silo, After being taken out and lail on the barn toor it would heat, but the catels at it as readily is erel.

20. 'Plhe best they ean have, coming nearer to green foddor than anything olse.

¿t. It produces milk of as goml fuality as any other foml, and more of it.

20. Fully as goorl for dry stork, or horses and eolts, as for milel eows.

2:3. From 55 to 75 pounds per day for cows, aceording to their size, and young stock in propontion.

24. I prefer to feed the stock one or two ferds of other food per day, but have lated good results fiom feerling ensilan alone.

25. 1 ferl 20 lead yearlings and two-year-olds, nearly 3 months on ensilage and a ifnart of wheat bran per day for carle animat. They came ont in the spring better than any stock of the same age I ever wintered.

26. Ensilage can be produced reary for nse for 52 per ton, and 3 fons are equal to a ton of Enelish hay. The hay in our market is worth, on an average, sou fer ton, making the ensilage worth, on that basis. S6.6ir per tom-a net protit of 84.67 per tom. Eusilage was sold in our market last rear and year before for s6 and sor per ton, and the purchaser considered it cheaper at those prices than anything else he eould feed to his milch cows.

\section{N. S. Fisu, Groton, Comn.:}

1. Arljoining feeding room.

3. $12 \times 13 \times 14$ feet deep. The ensilage was feet deep after pressing. I have num carried the walls mp, and it is 24 feet decp for nse in 185:.

4. Below frame of barn, concrete, plastered with cement. Above the frame, hemlock loards, 2 thicknesses, with paper between. The more pertectly the air is exchned the better: but by pressing you obtain that, though the sides are not entirely tight.

5. Cut straw abont 6 inches thick when loose, and boards 2 thicknesse's, taking care to cover joints.

6. Stoue, 1o inches deep; the more weight nsed the better, except the cost of puttiug on and taking off.

8. Corn.

9. Planted in rows, 2 grains in al place, about 18 inches apart.

10. My corn was right for roasting eals. The corn (grain) was quite acid when we used it, much more so than the stalks; shall put up this year hefore it is so far advancerl.

11. : 0 tons estimated.

14. Cutter driven by 2-horse tread power

15. We tilled in 2 days. If put in fast it is done with, but will settle much more if more time is used. If space is important, I thiuk 2 or 3 feet per day fast enongh.

16. Mine cost \$ 1.50 per ton. The larger the silo the less cost per ton.

17. 10 weeks.

18. Very nice.

19. None, muless it was left for several days after being novcel.

20. Was much pleased with it. 
21. No bad effects on milk or butter; better color than on dry feed.

22. It is good food for any neat stoek; have not nsed it for horses. Hogs will eat it well. Hens are fond of it.

23. 60 pomnds per day for cows.

24. Hay or corn-tokler at noon.

25. My stoek kept in fine condition while freding, and when it was nsed np, about April 1, they missed it, and milk deereaserl. Have no tests of gain or loss, but julge trom general appearances.

26. The cost of keeping animals is mueh reduced, compared with any former way of leeping. When you can feed well ey cows 1: months from 1 acre, the profit is well established.

\section{II. Frisiste, Killingly, romu. :}

1. Silo on one side of thrathing-floor, stock wu the other.

3. $47 \times 12 \times 12$ feet hight : this is divided loy a wall, making one 30 feet loug, and one 15 leet.

4. Stone laid in mortar.

5. 2-inch pine plank, plowed ant matcher, in sections of 3 fect each.

6. Barrels of stome, 1 so pounds to the square foot.

7. Lintire cost, inchuling cover', s300.

s. swert cortin.

9. Hrills $3 \frac{1}{2}$ fect apart, "ultivated with a loorse lore.

36. Whltell in full blonsont.

11. Hout :30 tons.

12 and 1:8. Filled the silo only once, and that with sweet cont ; do not think we slatl use sweet rorn again, althomgh it worked well. Onr ensilage wals not as dry as some we saw of difliment kimls of corn.

11. :-horse power and tolter.

15. 1s inches per dily, from woll and wet als often ats we saw any signs of heating [Perhaps this acconnts for condition noted in 1:2 and 13.-Eal.]

16. About 50 eents per ton.

17. 1: weeks.

18. Very much as when put in, excepting it was more juicy and had a slight smeIl of alcoliol.

19. None whatever.

20. Onr cows never looked so well.

21. Nearly doubled.

23. Forty pounds per day.

24. 5 pounds of bran to 50 of eusilage.

25. Improved in every respect by the ensilage.

26. We have very limited experience, but are entirely satisfied with it as a paying investmeut.

\section{W. Galinett, Enfietd, M. ('.:}

My experience with ensilage has been of a general nature. I have made no special experiments, such as to weigl folder prodnced on an iere, the best kind of corn, \&c. I have used pea-vines chicfly, beeanse in my first experience I fimmd stock preferred them to auy other material I had nsed, and they were easily and cheaply produced. With the system of ensilage. I am fed ding my stock at much less cost and tronble than ever before; they do their work and knep in much better coudition than when fed on hay aud fodler. 
Williay H. Gilbert, Richland, I. J.:

1. Ily silos are built at end of harn anl exteml into sille of hill. The botton of silos are 1 foot below stable thor with doms extending from top of silo to level of stable floor.

3. Each $36 \times 16 \times 19$ feet dere?.

4. Stone, 2 feet thick, plastered with water-lime. Bottom paved with stonc and plastered.

5. 2-inch plank, plowed and nuateherl.

fi. Last season I used common field-stone, estimated at 30 tons on ach silo. This season I intend to use barrels filled with sand, from 150 to 200 pounds to the sumare foot.

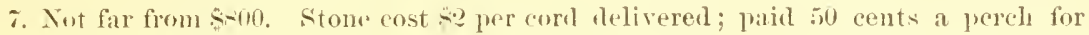
mason work; Stoo tor labor on bulling; excavation s.30; got sand for mortar ont of silo pit.

Q. Corn.

9. J'anter with lrill, 30 inches apart, and cultivated same as tielil-eorn.

10. When the ears are large thomgh for roasting.

11. I think 20 tons per acre a good average, wne season with another.

15. I like the sonthem com loest. It grows large and is sweet and juicy.

15. I place the cuttel on wall, so that the fred falls directly into silo ; ent $\frac{8}{8}$ of an inch, and from > to 10 toms an hour; keep 2 men in silo to level and pack.

16. 3is to 40 cents per tou for cutting, drawing, and packing.

17. : months.

1ร. fioud.

19. As good in April as in Decenber.

20. 5 tons will keely a cow as long as 2 tons of the liest hay.

21. 5 per cont. more milk than from hay. The lunter was No. 1; nlaror nearly as good as that made from grass.

2.2. My hories and hogs eat ensilage grexlily; diu not feed enongh to ascertain valne. 23. 40 pounds or 2 bushels to each heat per day.

24. I ferl $:$ pounts of bran night and morning, not with ensilage.

25. I never had stock to as well on any ofler feed; they gained in flesle aud health. Nevir haf cows do as well after calring.

26. I have put in 50 acres of corn for ensilage that has eost me, when realy for cultivating, \$433.10, including s.5 prex are for fertilizer and cost of seed, and 30 cents jer lour for tean; cost of cultivating will not excert 530 ; should I have an average erop it will not cost mole than sio to winter a eow. I think with good management that a farm will keep 2 cows the year for every aere cultivated. I consiler eusilage protitable.

D. II. GOOIELL, Antrim, I. $H_{\text {. : }}$

1. 2 silos, sirle by side; loors open into feeling rooms.

3. Each $10 \times 1: 2 \times 19$ fect derlo.

4. Stone walls, cemented.

6. Cobble stones, about 1 foot deep.

7. $\$ 1.1100$, for both silos.

-. Corn.

9. Planted with planter and eultivated with smoothing harrow.

10. When the ears are finlly formed, just before the corn begrins to glaze.

11. 30 tons per arere.

12. Somtlern White corn.

13. No better than any otluer.

14. Cint sinch long.

15. Put in ahout 30 inches in tepth per das.

16. Alunt 90 cents, but can lo it for 75 ecents.

3 IIL 
17. di weeks.

1:. Exeellent.

19. None at all.

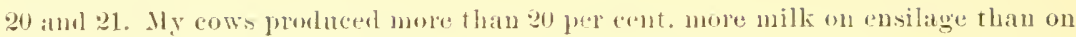
best hay. Quality of milk as goml as wn any other ford.

2.2. For fattening oxen it promel the hest feed, in conuection with corn and cottonseed meal, lever used.

2:3. Cows in milk ate 6o pombls pere day, with 2 to 4 guarts of meal.

24. Witli other forml.

25. Jomng cattle ferl rhielly on eusilayg. with a small fuantity of poor has, no meal; were fit for the butcher in spring.

24. Exceterlingly protitable, all things considered.

J. P. Goonder, Peaboly, Mass.:

1. My silo is loeated at the northwest comer of, and opens into, the harn. Ilalf the depth is below the barm thor.

3. $40 \times 1.5 \times 1$ - fiet deepl.

4. Stone, fircol with cement.

5. Plankis, crosswise.

i. Stonc on the planks.

7. Alunt soon.

c. Com prinoipally.

10. When the corn is berimning to grow on the ear.

11. Alout:30 toms to the acre, on the arerage.

1:. The best kind of entr for ensilater is the latrest.

14. 17 to 11-home-power engine and cutter.

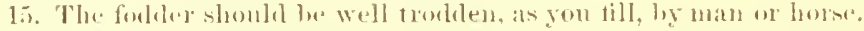

1ti. Fon bu cents to st pees ton, arecorling to the distance to hanl it.

17. 210 to 3 momiths.

19. Nuाre

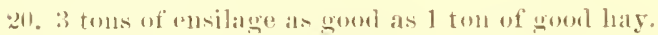

2). Food milk amel pood linttrel.

2.2. fiosel for ally stock.

2.:3. (i) pommis per dis for a mileh eow.

24. Alout 30 pomels morning and night with gratu thrown on it.

5.). Better than on las. They look sleck, drink less. and are happy.

Jacob Glieex, Happingers Falls, X. J: :

1. Feet from eow-stable at and of the lann, which fomm one sicle of silu. Is on sille-lill, the top level with the roalway.

3. $30 \times 20 \times 00$ feet derel, divided lis a partition.

4. The walls are 13 teet high and 3 towt thok, of limestome laid dry and facel with cement; above this it is of mateher boards. The partition is also of matched boards, double and filled with earth.

5. 1 $\frac{1}{2}$-inch plank.

(i. $1 \frac{1}{2}$ or 2 feet of stone.

†. \$600, exclusive of firm labor:

¿. Corn.

12. Dutchess Connty White.

14. Cutter run hy a 5-horse-power elgine; cut $\frac{1}{2}$-inch leigth, fast as 2 men could liamlle the fodder.

15. 2 boys levelerl it in silo.

17. 1 munth. 
19. Was hot and smelled lika a brewery.

19. Last was guorl as the tirst.

90. Cittle were vers fond of it.

21. The milk was superior to any I rere talsterl.

20. Jomuge calves ate it realily, but also hatrl milk until 6 weeks old: then only had ensilage with a few mats: they grew and looked well.

23. 1 bushel of ensilage twice a lay for cows.

24. Suall gluantity ut hay at noon witl mual.

25. All suem to be eorrect.

26. So far, with 1 year's trial, eusilage is a perfect sllceess, aud equals all our expeetitions.

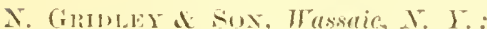

1. Cows are stabled in hasement of harm, and dow opens from the midelle of hatels side (bank side) inte the silo. Flore of silo alunt thee feet lower than thor of stable.

3. $3: 2 \times 12 \times 10$ feet der 1 .

4. Conepete. 14 to 16 juches thick. P'osts set in the glonnd and lined with :-ineh plank, put in as wall is huilt. Any kinul of stone userl. One part eenent to 5 parts sand, mixed whild dry, then wet so that it will pour from the pails in which it is calded. After the posto and planks are taken down the walls are plastered with eement, male with less sand. Bottom covered about : inches with gravel.

5. Plank.

6. 12 to 1 is inclues of stone.

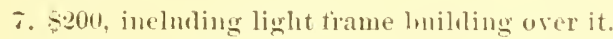

s. Corni:

10. Cut when "nublins" are firmert.

11. Estimated at 101015 toms.

12. Any limil that produces a large growth.

15. Set the cutter over the silo, and drew the corn alongside, ent about of an inch loug, and paelied by poug and hoys.

16. is cents per tom.

17. 3 montls.

18. Chamged colver somewhat; a slight odor.

19. Nome.

21. They like it, and do well on it.

21. The milk is reduced at comlensing factory without complaint.

2.2. They all eat it.

24. Both.

25. frood.

26. We are now builuling one that will holl more than 400 tons. Milk is the important prorluet in this region. "The "limit "formerly was the amount of hay that a firm conli probuce. Any farm can grow from 5 to 10 times as mueh green corn-forder as it can of hay. With the silo the "linit" is not the hay lunt the ensilage. The value is caused by the increased probluet of foul per acre.

\section{A. Guriakli, Monsey, I. Y.:}

1. We cammot speak of "laborate constructions or well-rligested plans, havmo simply dug a cellar muler a part of onr barn, with stone walls on three sides, and the earth held "1 by buads on the fourth side. The florol is earth.

3. To be emvenient, a silo shmuld le long and narrow with an opening in the narrow side on a level with the thor. The exposed surface, while comsmung the eontents of a silo, should be as small as possible. The opening should be directly aceessible from the stalle. Silos sor 10 feet wirle, and lomg and derep in proportion to the regnirements, would be the most convenient and servicealule. 
5. We covered ours with clean stram about 6 inches, then common hemlock boards.

6. Stones 1 foot deep. This weight was amply sufticient for z teet of ensilage.

8. Com mainly. We have found that straw (rye, wheat, or oats) could be advantageomsly mixed with green eorn in the proportion of $\frac{1}{4}$ of strit straw will absorb a prat of the juice of the coru, and becones equally palatable. There is no donlet that clover, rye, and poliably bog and salt-meadow griss will prove great resources for the farmer if proverly ensiloed. We have experimenten satisfactorily witl clover and rye.

9. In rows 3 feet apart and the stalks 6 to 8 inches from one another in the rows.

10. As soon as tasseled.

11. We have had fine crops of corn, planted as above stated, the yield of which has not exceded 20 toms jor ace. This wejght is reduced fully one-thind after 3 months in the silo. A safe estimate wonld he an arerage of 2 to 10 toms of ensilage fiom an acre of good, well cultivated land.

12. Corn of rank and puick growth is the best.

13. The giant varieties of sweot corn wo esteem preforable to eommon coru, as growing more fuickly aud griving stalks more juicy and of softer texture.

14. Onr machine ants the corn 3 of an incli long, and erushes the stalks so every part is eaten.

16. The cost of cuttiug the corn grecu, carting it to the silo, and preparing snitably, we have found not to exceed the cost of cutting and curing in the molinary way.

17. 3 to 5 montls.

1:. From 1 to 3 inches at the top is all the hoss we have experienced.

21. Cows give as good milk on ensilage as they do in grass, aud the lmtter has tho same (o)lor.

2:3. A cubic foot is sutticint tor one enw.

:4. We have urer feal it exclusively. Animals regnire a variety of foor to leep iu apletite aud good liealth.

26. There is grat economy in the spstem; how nucl we are not prepared to state. The exalgerated acoonts publisholare very projulicial. With the primitive arrangements deocribed, om surcess has bern wh lair that we camuot hesitate to recommend even the poorest of one fammers to nse silos; tobuild them as best they ean. A simple tremeh in the groum, well corered, will answr. Structures marle for the purpose are more lumble, more convenient, and may rave the fodder better, but all ramot afford the exponse, while all can select a dry sput, dig a trench, till with green fudiler, corer

ith the rarth dug out of the trench, and have juicy, palatable food for their stock in winter.

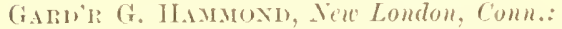

1. Filo locatod 100 feet from cow stable on acenut of lay of land, so that ensilage has to he brought in in cart daily; if one has a sicle-hill baru, silo bult arljoining cow stables would be proper plan.

3. 51 $\mathrm{x} 15 \times 15$ feet.

4. Stome wall laid in mortar without regard to thickness, one-half lueluw level of ground, other lualf graded ul, to level of sill by stone and rocks "xearated.

5. 2-inch plank.

6. Rocks, 200 ponmels to square fiout.

7. s-00, incluling superstructure.

ह. Corn.

9. l'Janted with coru-drill, 2 rowsat a time, which, with man, boy, and 1 pair horses, marks, drops, and covers 1 acre per hour.

10. At fullest growth, when ears are forming.

11. Whole crop averagert 15 toms per acre, 4 acres of which was swamp, very poor; on good eorn-land lial : 1 tons per acre.

1\%. The largest sonthern corn. 
14. Jarge enter rm by pair of mules; not power enough; this year shall use a stean ("ngine.

15. Ensilage leveled when put in and rolled with a heary garlen roller.

16. S.2.45 per tou.

17. 6 wereks.

I-. First rate.

19. None.

20. Excellent.

21. Milk mueh richer, and an increase of 30 per eent. in quantity.

23.55 joumls.

24. Fed twice a day, with 1 pint cottonsed meal and 3 fuarts bran: nothing elso $\mathrm{n}$ arldition to ensilage.

25. Milch cows abont held same weight; heaviest milkers lost ; dry cows, heifer, and bull gained steaclily; 2 latter at rate of 1 pumd per day.

26. Cost of feeding on ensilage as against hay, roots, and meal, 1 too 3.

Hanipox Nomal Schonl, S. C., Armstroxg, Principal, Hampton, Ta.:

1. In one cormer of harm, door opening into feed alley.

$3.14 \times 17 \times 23$ feet deep.

4. Bricks aud cenent.

5. Boarels and straw.

6. Dry fodiler.

7. Ahont 17 is

8. Corn.

10. At the time of tasseling.

11. 10 tous.

1\%. Sontliern white corn.

14. Cut in lengths of $\frac{1}{2}$ inch.

16. Cost, s1 per ton.

1\%. 4 montlus.

15. No thange in color"; condition goenl.

19. None.

20. Hoes well as a change.

21. Inereased the tlavor of milk somewhat.

23. Aluont 60 poumls pere das.

24. Fod witl other food-about 3 quarts of wheat bran.

25. Fed I month only. There was no perceptible change in the condition of the stock.

26. Works well with other fool; does well as a substitute for roots.

The "xperiment was mate with:30 tons ensilage ouls. This was used in feeding for 1 month; hence the limited opportunity for observation.

\section{J. H.irrigax, Foxborough, Ifass.:}

1. Dours open from silo to feerling room.

3. (i0 $\times 11 \times 1 \%$ feet deep.

4. Rongh stone, lined with conerete.

5. Boards.

6. Rocks, to the depth of 15 inches.

7. 555 for cement. I did the work witls my men in suare hours, fluring storms weather.

8. Curn.

9. I plant in rows, and cultivate with suoothing harrow and eultivator.

10. When in tassel. 
12. Southern Write corm.

14. I ent the fochler 3 inch long; entter striven hy a two-horse power.

17. A nonth.

12. Int slightly changed in color, and was perfeetly preserverl.

19. Nu cluange after opening.

20. Z toms erpual to 1 ton of English hay.

21. The list.

23. 60 jommis per das.

24. Mixed with cottonsed and eormmeal.

25. The emulition of the stock was goot. A cow that was old and por, and gave but me yuart of milk per day, was fell bo pomels eusilage, 2 yuarts cob meal, and 2 quarts cotton-seel. She gained six ynarts of milk per elay, and was in gool condition for the lutcher in three months. In all cases I timl that the cows preforensilaga to has, less.

26. I think eusilage is protitable for any man having 6 head of eattle, but mot for

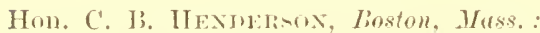

1. Silo smok in gravel bed in back part of barn cellar. The top on level with feeding room in tiont jort.

3. Length. 12 fuet; brearlth, - feet : riepth, - feet.

4. 2-inch platik, tomgned and groured.

5. Sam11.

6. Bancels filled with small stome, 90 pounds per somare foot.

7. between 550 and $\$ 60$, less value of gramel.

$\therefore$ liowen in sejutumbr, 1--1, anul winter rye in June, 1-a.?.

9. Ryt sown hroadcast early in Oetober.

10. liye cut just aftrer liealing.

11. Estimated weight of rye from to are, 1: tons.

14. life cut three-ynarter's of an inch in lengtl.

15. Cutter on platform over silo, one man mowing and hanling in hand cart, on cutting, some ferling and cutting, all thres spreating and trampling at intervals. Time employed in filling silo: 3 rlays.

16. \$1.15 jej ton, inclukng mowing and hanling.

17. Nilo closed and weighterl June - : opened July 1\%.

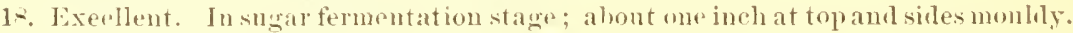

19. No deterioration prepceptible mn July :-

20,21 . I cow dry, eming in in Angust, in gom healthy condition. Another milking in similar condition, giving same 'puntity, but richer wilk than when grazing up to July 1 \%

23. Nlunt 50 poumls per tlay.

24. 4 feecls pri day alone, 1 and 2 feeds respectively of meal or shorts, griven separately.

2.5. Combtion and health rers crool. Relative woirht not testerl.

26. No exact estimate male as to profitaluleness, lut alvantage of feeding ensilage in winter as well as late in smmmer, when gratss is parched and seants, incontestable. Ensilago apparently not alapted to horses, 20 which were given about 8 poumls a day each having within a fow days suffered from acuto inflammation of the intestines, which could not les traced to any other canse.

\section{Jons Wixsom Joxis, Portland, Me.:}

1. The hest location for a silo is in the builing where the cattle are forl, or eonneeted with it.

2. As near symare as pussible if of wool, or ronul if of stone or brick. 
4. I have recommended lining up the insile of a luy in an ordinary barn with one thiekness of rough, straight-edged bonts, nailed np and down.

$\therefore$ Corer with any oll lwark-a laver of straw under the bounds, if eonvenient.

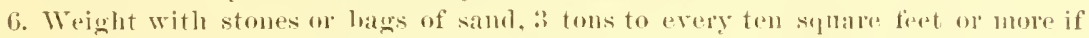
the silo has not been filled slowly, or is less thin : 21 feet lighth.

7. To bring silos intu general use they should be made in stahles already huilt, and not cost orer 涪 to

- Corn is lest. Rỵe is good, and ean he cut and eorn planted on same gromul. I raise sweet corn for packing, and ensilage tlue forkler.

9. Drills 3 feet apart, $1 \frac{1}{2}$ to 2 linshels to the acre.

10. Before it begins to try.

11. 5 tom per acre is a gool yield. Rye is to \& toms.

1:. The Virginia White eorn is goon as any.

13. There is very little if any difference where loth are raised espereially for forlder. You can raise a erop of sweet corn and the forbler is rers nice for ensilage, lont aftur raising a crop of other corn the fodiler is of little value.

14. Iachine shonla be set to rut $\frac{3}{x}$ of an incli. A large cntter and steam power are lest. An ordinary hay chtter will to the work, but it is slow.

15. I think it best to be $3 \mathrm{or} 4$ weeks fillimg a silo, or evoll longer, if it is : 20 or : feet high. If you are tilling sereral, till all a foot or so a day, and if a day intervenes it is all the same. The foulder shonld be kejt level and tronl rey'y hard, and every morning hefore aur new is put in it shmbl he thoroughly trodten. If high the weight of ensilage helps to make it solid.

16. It repuiles 4 men to run the maehine and pack from 6 to s tous a day.

17. From :3 weels to 6 months or more.

18. A little on top and next to the boarling monluy, the of her is moist, lats a yellowish color, a sutell resembling hrewery grains, and a slight acid taste.

19. None, if well packed.

20. Cattle like it, and thrive on it, better than on the best early-eut hay.

21. In some instances people have complained a little of the taste of the milk and butter: I lo not think it injures eithers.

2.2. It is more valualile than the best hay, in fact when ferl with this, eattle will not eat liay. I fattened 100 lead last winter.

23. 3 tous will go as fir as a toll of hay.

24. I fed twice a lay and gave a little lay at noon. For fattening cattle cotton seed meal or colnueal on the ensilage.

25. I never saw cattle fattell as fast on anything else.

26. I thiuk a stock of eattle can he kept for unp-fourth the expense of any other method.

N. P. Joxws, Metrose, Hass.:

1. Silo arloins side of harn.

3. $30 \times 14 \times 12$ feret dee $]^{2}$.

4. Two conrses of harl-burnt brick laid in cemeut, bottom cementerl.

5. Planks fitted across silo.

6. Stone, as many as eau conveuiently be placed on plank.

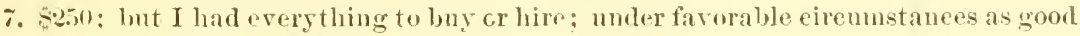
a silo comld be built for sis:

8. Com fodder.

9. Planterl in drills, and enltivated with horse-hoe or ylow.

10. When stalk and ear are full grown, but liefore commencing to ripen.

11. Our best riell is estinated 30 tons jer ar'p.

12, 13. C'se Western or Northern yellow corn, bnt think a variety of sweet corn like Stowell's Evergreen better. 
14, 15. Cut from to to inches lung, with large folder cutter, run by lorse power. Two men are employed in the field entting, one hanling, wne tenting machine, one leveling, and one tramping in silo, and we cut up and pack from 30 to 35 horse-cart lo:kls a day.

1i. It costs ne s1.50 per tou.

17. Eight weeks.

1-. $1 \frac{1}{2}$ to 2 inches at tol was momlly and nufit to feed; mulerncath this it was a brownish green, with an alcoholir odlor.

19. Not noticuable.

20. Cows eat with relish and alpurently do as well as when ferl good English hay.

21. Milk as grood as when feedling English hay, giving rich eream of a nutty tavor.

2:. Calves while ted ensilage wholly, wrew well, and were apparently health.

23. One aun a half bushels a day.

24. Feed hay at noon; also feed grain, three pints corn meal and three ruarts shorts.

25. Do as well and ar: as healthy as when fed upou hay.

30. I think ensilage is profitable. In the spriug of 1--0, the season buing ary, and the hay crop promising to be light. We plowed and planted fon two to three acris, a part as late as Jume :2, which made njwarls of forty tons of ensilaye, hesiles what was fid green. This gave, with a molerate ontlay for manue and labor, an amount of fodter in every way equal to ten tons of English hay. It is hauled fiom the field and paeked in the silo witlout the labor and delay of curing, aur whether the smu shines or not. It is a valnable ardition to our supply of folder; which can be relied upon when the hay crop is light.

\section{IIExry Laplah, Oconomomoc, His. :}

1. The intention is to build more barns and have them joined to the silu.

3. 2 pits $12 \times 30 \times 16$ feet deep.

4. Against the bank, stone; all others of concrete.

6. Stonr, 1:5 pounds per squille tiout.

7. $5.000 .116 \%$.

s. Clover and corn.

9. Rows 3 feret - inches aprart, about f lunshel to the acre.

12. The native, or that which prows best.

1. A large straw enttur, lun by a steam engine.

18. (iood, "xcept about 3 inches on top, and an inch along each wall alout 3 feet down. I think this was owing to the silo being filled before the cement was dry.

19. Nome, muless shaken tu and lete for a lay or two.

21. The thow of mille was increased.

:-2. Excellent.

21. Mostly alone, but to milels cows gave blan and oil meal.

25. Ilealth aurl comlition gool.

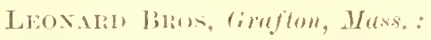

1. 'Top ot wall ou level with fexling tloor.

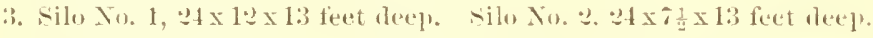

4. Grinite, laid in cement. Walls gronted inside.

5. Plank ruming cusswise of silo, cut 2 iuches shorter than wilth of silo.

6. Cobbles: abont 150 pumbls to the sullate foot is necessary and sufiedent.

¿. Cost of loth silos s.jou.

S. Corn, rece, and rover.

9. We plant corn in lrills about 3 teet apart, aud 3 to 5 kernels to the foot.

10. When the ears are well set, not before.

11. About ?1) tous. 
14. We cut corn $\frac{g}{3}$ of an inch in length; rye and clover $1 \frac{1}{2}$ inclies. U'se 3-hores steam engine.

15. Keep 3 or 4 men tranping down the folder constantly while cutting.

17. 4 weeks.

18. Slightly acid, and of a brown color.

19. Loss very slight.

20. About one-thirel of that of the hest of hay, pound for ponnt.

21. The milk made from ensilage seoms to be fully erpul, if not superior, to that marle from best lias.

22. For fattening, we think it snperior to anything in the slape of coarse fockler.

23. 50 pounds for milch eows.

24. With 1 feed of poor hay and 6 to 7 pomds coton seer and cormueal, 3 of former to 1 of litter.

25. Better than evire before, perfectly lualthy to all appearances.

26. The best food for cittle, and most economical ever produced.

\section{Lixcoly Bros., Woodstock, Ft. :}

1. Away from barn, connected by a track with car. There was no chance to join to the barn.

3. Two silos, each $30 \times 15 \times 22$ feet reep.

4. 18 feet of concrete, and 4 feet of frame work.

5. Boards, crossways.

6. One foot in repth of stone.

7. $\$ 300$ for materials, snperstructnre included; dich the work onrselves.

s. Corn.

9. Our corn was planted in hills $3 \frac{1}{2}$ feet apart, one kernel every 5 inches, lont it did not come up well, aud some were three or fom feet apart, so there was not as large a crop as we hoper for; cultivated as long as wo conld.

10. Some of onr corn was in the milk when cut, and some just well tasseled ont. We conld not see much difference in feeding; stock ate the wholu rarlily.

11. We had abont 120 toms, ealling one cubic foot 40 pomels, from eight acres. The giehl would have been more if it had not heen so dry.

12. Think the sonthern the hest as we get a larger yield, and being cut, all is eaten rearlily.

14, 15. The corn was drawn to silo as fast as cut, and eut $\frac{n_{5}}{5}$ of an inch long, with a cutter run by a four-hors power steam engine, and elevated by earrier to top of silo. We diul not quite fill onr silo.

16. Comnting interest on engine and cntter for one year, it cost ns less than -jonts per toll.

17. One month.

12. The ensilage hat a light brown color when openerl, with a slightly arial taste. Our cows dial not take to it the first feeding, but it was all waten up before the next - feerling, and after that most of them would eat it in preference to hay, if lotl were fed at unce; two or tbree would seareely eat hay if put before them, but wonlut wait for wisilage.

19. Ours kept abont the same mntil ferl out, the 15th of May. If any cliange, a hittle more acid smell.

20. For milch cows, we think it alseal of any feed wo arer tried.

21. The cows gave nearly or yuite as much nilk as in smmmer when on grass. The effect on butter was as marked as in thw yield of milk, making full as moch from the same amount of milk, and being nealy as high colored as smmmer buter. We have regular customers for onr hntter: all said that it was the best butter we ever marle in the winter, and nearly as good as the bost of June butter. 
22. Crood for all horned cattle. We feel a t't sheep, ensilage twice amb hay once a. das (no grain), ant they did well; with some grain would do full as well as on hay.

:3. From 55 to 90 pounds per head per day. We gave what they would eat elean.

-4. We fed thres quarts of cotton and linseed meal mixed, per day, per hear to unr milch cows. We tried the difterent kinds separate, but for milk the mixed feed was best. We fed our cows dry corn fodkler once a ras part of the winter, but they liked ensilage better. Onr calves had ensilage norning and night, and hay at noon: no graiu. The did as well as we ever had calves do.

25. Our stock came out lonking well, some of the neighbors said as well as they ever saw. We fitted an old cow that was so thin that we expected to lose her: she dressed (500 poumls gool beef: was milked all the timu.

26. We think ensilage is protitable. Have put in more com this year.

\section{JaMes Lippixcot, Mount Holly, X. J.:}

1. Silo 200 hundred yands fiom cow harn.

3. $19 \times 10 \frac{1}{2} \times 9$ feet deel.

4. Brick walls, eight inclues, pointed with crment, cenent buttoun.

5. Two inch plank.

6. Siml, jut on loose.

7. siln.

s. Corn.

9. C'ultivated same as ticld corn.

10. When tit for lwiling.

12, 13. Sngar corn the brst.

14, 15. Lse i two-lorse power, and cut in inch lengtlis: get it into the silo, pack firm, and cover-all as som as possible.

17. Two months.

18. Ensilage in splendid combition.

19. Kept in woml condition until all fed.

20. The best for milk of any foed that I ever usent.

21. Gourl.

2:2. Mr eolts alid well on it.

23. (ne bushel per enw.

24. Fed twice a day, arlding three duarts bran amd corm meal at each feeding.

25. My stuck dicl well; never harl a cow to get ont of tix while feeding ensilage.

26 . I cousirler ensilage the "leapent, best, aud most profitable feed that a dairyuan can nse.

\section{S. Littaf., Georgetoun, Mass. :}

1. Opens into the feediug-room of side-hill barn.

$3.20 \times 30$ (lepth not stated), divided by wall in center.

4. The earth heing vers retentive, plastered on the earth with cement up to the frost line; and then laid a concrete wall for the rest. Covered the bottom with 10 inches of stoues and cementer over the wlule.

5. Jlank.

fi. Stones 15 inches thick orer the entire surtace.

i. $\$ 150$.

8. Corn.

9. Planted in drils 3 feet 9 inches apart, and one or two kemels 8 to 10 inches apart in sow.

10. Cut when the fullest of sap. lrefore any bottom leaves have tumed yellow.

12. Blonnt's prolific. It is rers finll of leaf to the gromud.

14. Cut in soncli pieces. Used horse power but steam is vers much better. 
16. From \$1.75 to $\$ 2$ per ton, with steam power; another gear will do it for \$1..50.

17. :3 montls.

18. Snculent, sweet, and nice.

19. better when it came ont than when it went in.

30. Iietter than the grass in oul wornout pastrues.

21. Nuch the same as turning cattle to pasture.

3.). Harl complete snceess in feeding cows not in milk on nothing but ansilage.

They were fat and nice, and satisfactory to onc lontrhers to kill.

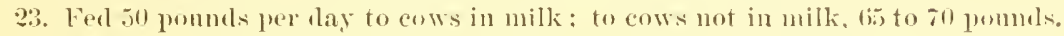

24. Fal the same grain as when freding hay, aml hay once a day.

95. Stoek ferl on ensilage during the winter; eano ont this spring in fune endition, hair indicating perfect lealth. Never lad stock look and appear hetter, if as well.

of. The protitablemess of ensilage depends in a great measure on the anum of oleen fodter raised per acre. It is the enormons crop whieh can be raised per ace which settles the whole anestion.

\section{Prof. J. M. Melirvos, Kunceille, Tenn. :}

1. 2 silos, aljoining, on unper sidn of hill-sile harn, the top heing level with first floor and bottom level with floor of hasement, with doors between.

3. 21 feet 3 inches $\times 10$ fert ; inclies cach; depth, 11 fect.

4. Dirick wall 1: inches thirk, each long sille at midlle strengthened by buttress 16 inches thick; sides aml bottoms lined with cement.

5. Planks : inches thick, placel transversely on layer of ent straw.

6. Olal brieks, stones, or anything. Ton much weight is frequently applied. We used 100 pounds per square foot, (tou murh); floor of silo covered witl pxpressed juices of forage.

․ The 2 silos and extension of roof of barn over them, eost 5.30 .

$\therefore$ Corn, clover, millet, dlumra, soreglum.

9. Thinly drilled in rows 3 feet apart; 200 pounds compost drilled in witl seed, thomglils cultivated.

10. The corn beginning to silk, grain just forming. This is a practical question. If allowed to stand longer the lower leaves lecome fired and valueless, witl consednent Jass of weight.

11. Red 1Iomuluras sorghum, 11, -66 pommls; gonrd-seed coln, 6,327 pomuls; orange sorglum, 7,9], pommls.

12. Honlumasorghum is a forage plant of great promise. I think mueh better than corn.

14. Cutter driven by a me-horse power. This sliced up a cart load-500 poundsinto $\frac{1}{2}$-inch pieces in five minntes.

15. The eorn fell directly into the pit and was heavily tramperl.

16. (i-⿱⺈

17. 3 nuontlis.

13. Sound and fiesh, but slightly elanged in appearanes; the edges and top alono to the elepth of an inch being somewhat damaged. One silo was mot opeurel for fifteen months atter it was filled, and with the exception of the onternost liyers was found in very fail combition, somewhat more acid, but in other resperts eynal to the other silos opened the previons winter.

19. Contiumed somml to the last and exp I] in ynality.

20, 21. All on milch eows receiving ensilage showes a notable improvement in milk. Butter madr from milk of cows ferl on ensilage of excellent flaror.

2.2 to 24. Three vearling steers ferl exchusively on lomg forage: one weigling 493

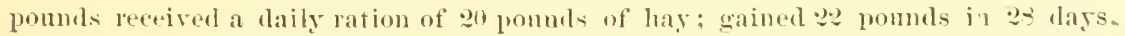
Another, weighing 4ir poumds, receiver 10 pound hay and 20 poumb ensilaw : gained

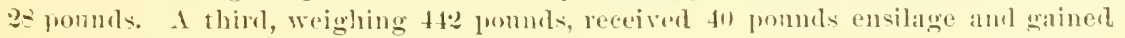


30 punds. Two pounds ensilage gave better results than one pound hay. It is plain that animals shonld be fed on mixed rations of ensilage and matter's rich in alluminoids.

2.). In all experiments the animals were hearty: bowels open, but not too loose, aud their nigestion goorl.

21:. Of decinted value, especially in south where has is scarce. Ecounny of space is an immortant consileration. An immense amount can be packed away in small space. Again, in uine seasons ont of ten, it is difficnlt tn cure fodder. The least rain monlds it and it will monld if stacked; withont weeks of exposure to cure it, ensilage can be put down withont regard to weathes.

\section{W. W. Merrian, bi Liberly street, Neu Tork, N. I.:}

1. Distant 20 ieet from feed alley.

4. Extcrior wall: teet thick and 16 feet high : partition-wall $1 \frac{1}{2}$ feet thiek, of stone and cenent, forming 2 pits, each $14 \times 1.5 \times 16$ fert. On this wall 1 built a frame, 9 -foot posts, sided up with grooted and tongued boalds, covered with building paper, then

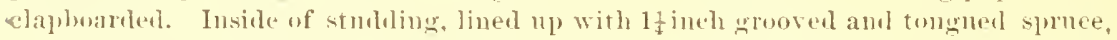
well painted, and thes with iusile of silo wall, so that the eovers may run down withsut an impeliment, making a total height of $\because 0$ feet. The tlour is gronted with gravel ant eement, - inwes thick, and insidle of walls plastered with cement.

5. Covers lis fiet long and 3 leet wide, math of 's-inch spruce plank, grooved and fongund : cleats of same bolted on.

6. Stome are piled on these eovers to extent of 300 to 330 ponds per stuare foot.

7. $\$ 1.000$.

-. Corn and elover.

9. Com dirlled in lows 40 inches apart, s to 10 kernels to the foot, or a hushel of seetl to the acre.

10. Corn shonld be cut when in full bloom, and just as the silk is showing. It is then full of sap from root to preak. Clover in full hilonsom.

$1 \%$ sonthern wourd-serel corn.

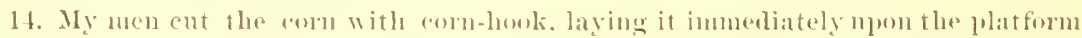
or wagon shelvings, when it is taken directly to the silo. The sooner the stalk is rnu through the rutter and in the silo after leaving the libll the hetter. With a twolonse power I eut a tom of stalks sonch long in 120 to 14 minntes easily.

15. The cut foulder is kipt leveled ofì and tread moderately each 2 or 3 loarls. There is no neerl of covming the ensilage earlo night.

17. Not less than tiol diys.

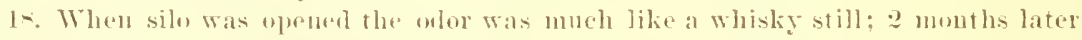
it was more likn a molasses rask.

19. None; on the contary nuch inproved. I remme one cover at a time and take out the ensilage in a perpendicular line to the bottom of pit, then anotler cover, and si) $\mathrm{mll}$.

20. Nothing so exactls suits the purpose. Whon cows are first fetl with ensilage, ther ho not eat it with relish. but alter a few days they eat it in preference to now hay.

Z1. When the ensilage was exhansted my cows fell utt' in milk fully one-t fuater: even the addition of wore grain with hay womld not prevent it. The eream dis not make so much butter, nor were the color and thar equal.

2:?. The past winter I honght some 3-rear old western steers, thin in flesh. but healthy and fed them for 90 hass. The ration per day was 44 ponuds ensilage, 6 pounds corn-meal, and a bushel of cut corn-stallin. They showed marked imporement in 30 days, and continnerl to thrive heyond the experience of feeters in the oh old way. At the end of 90 dars, my ensilage being pxhansted, I shipped the steers to New York, where they showed a gain of over $1 \frac{1}{2}$ pounds per tay. and that after a cold night's ride in open car. 
93. Cattle should be fed on ensilage as upon auy ofluer toorl, viz, all they will cat elean. I ton a month of ensilage is a full ration for an animal, ambl few will fat as much if properly honsed, regularly ferl, aud well carrel for.

24. I prefer a midalay ration of dry feed, and feed cows in milk, and fatting oxen, more or less grain.

25. Every animal I have fed on ensilang has inproved in eondition and mioyed the most perfect health. Jusey ealres eat molage with great relish at fonr weeks of age, and I show as mach improvement in a rall dropperl in October as I could pusibly if raised ou the lust pasture.

- 20. There is no folder for winter nso like ensilage, and I an thinking of anopting. it for smmmer as well.

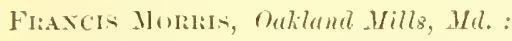

1. Feed must be carted, therefore ensilage it where it is grown.

3. 11 teet wide at top, i feet at bottom, deep as convonient, any length renired,

4. Eastl.

5. Eartl.

6. Farth. 20 incles depth.

7. 30 to,, $25 \%$

-C Coln.

9. Urills, 20 inches apart; work twice.

10. C'nt it in tassel.

11. 10 to 20 tons.

12. White corm.

14. C'nt it with nowing maehine, haul it on wagons to cutter, wheh delivers it in the silo.

16. 10 to 12 cents por ton, for the labor alone.

17. (i) daiss.

1-. It should be taken out of silo, thrown into a beap, and kept a day before used

19. No loss whatever.

20. Half the value of timothy hay.

21. Ensilage with Indian meal makes the best butter that has been mate. Ensilage is free from the moxions weets that frequently poison milk.

3.2. frood for all aninals.

23. Cows will eat 11 leer eent. of their weight.

24. Neal and oil-cake may be fed with it.

25. All animals improve on it.

:6. Timothy haty is worth here seo per tou. Corn-fokler is worth half as much. 'l'his makes a crop of corm-tudder of 20 toms jer aere worth soo for feeding stock.

I am elearly of opinion that silos shonld he put in the fiehl where the corn is grown. My fodder was analyzed by the Jew Jersey Agrientural Experiment Station, aud took rauk as No, 2 otit of nine samples. This shows that the earth silo is equally as govot as the wood, hrick, or stone silo, and is male at a tritling expense.

The turnip donbled the grain crop of England. Ensilage will change the agriculture of all maize prodnefng countries, and increase their poducts probably in a much greater ratio.

There appears to be an inclination to argne side issues. The New Jerser lerienltural Experiment Station has made an elaborate trial to prove that there is as much feed in dricet fodder as in ensilaged forder. I have no douls of the facts, hut I lave forty acres in corn fodler, and I expect to ensilage it, and shall do so (without hiring extra hands) at the rate of 100 tons a day. If 1 hat to enre the same I shonld regriro an additional popmlation on the larm, and then where to put it after it was cured monk he hard to say. 
Capt. (i. Mortux, Essex, Гt.:

My first silo was simply a trench in the gromml, eovered with a few boards and weighted with 2 feet of earth and stoue; forlder put in without being cut came out perfectly jueservel. The next year I built a stome silo $60 \times 1:$ x $-\frac{1}{2}$, and last year a wooder silo $153 \times 19 \times 20$.

5. Boards.

6. One finot depth of stone, or 10.1 ponuds jer symare foot. (See 19.) The more the better.

7. Stume silo enst $\$ 100$. Wooden silo, si31).

c. Corn.

9. Drill with planter ? bushels to the are. cultivate with a smoothing-harrow antil a foot high, then use lurse-hoe.

10. As soon as in tassel.

11. Average :01) tolls.

12. Sonthern white and blomit's prolific alle the kimls I lave nsed.

14. One horse-power.

15. With three neen aud two horses put inte silo 10 toms gere day ; cut 3 ineh

I6. 40 cents yer tun.

1\%. Oue moutli.

18. Warm amb slightly acid, hut eow liked it and increaned in milk.

19. As 1 used it I noverl thu stone nutil I had 2 feret, or a weight of 300 pounds Ger square foot, and the ensilage improved in qualit? all the time; better on 1st of Mat than in Octuber.

:0 to :5. The past wintel 1 fiel bothing but ensilage for 4 months to all stock: when enws began to cone in, 1 st of Feblualy, fed 4 quarts of meal and hran. reduc-

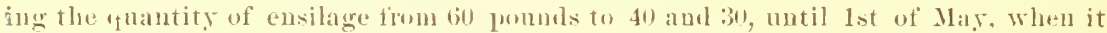
was gone. I then inereased grain-ferd to $T$ gnarts, but cows fell oft in milk as snoul

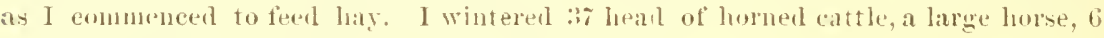
hogs, and on fowls: cows were fat all winter.

\section{J. G. Motт, Lansinglum, D. I.:}

1. At one end of and opruing into a han thor. from the opposite side of which start the teteling alleys tor 4 - liealu of cattle.

3. 1 is $\mathrm{x} 20$ feet ; nean height, $17 \frac{1}{2}$ feet.

4. Walls at the bottom are of lujek laid in eement 1 foot thiek, 3 feet high : on this wall is a plank laill in exment for a sill: the remainder of the wall is of studiling and y.inch plank, with two thiuknuses of tarmel paper; and over the paper, buards. The How is of loriek, lain in amb roverest with cement.

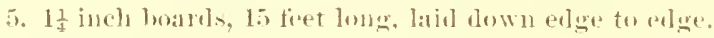

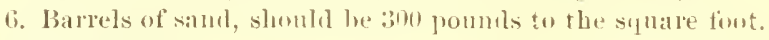

7. Abont $\leqslant 150$.

Corn.

9. Drills 3 feet apart, $1:$ keruels to the foot.

10. When enon is in tassel. entrs just forming.

11. 14 toris.

12. Southeru hurse-twoth.

15. Pack closely in silu: omght to till at least 4 fuet each day.

16. $\$ 1$.

17. 70 dars.

18. Swoet and juies, of a light-glecen color.

11). Not any.

20. Next to enorl pasture.

:3. 50 promuls ju+r das.

24. Eusilage twiec a lay, hay once: for fattening, two tuarts of meal with the eusilinge. 
25. Cattle, fed neal with it, sold readily for beef, which entuled any grass here; was swert ant juiey.

2f. One acre of eusilage will keep - head of eattle 100 days. I will build three more silos this year.

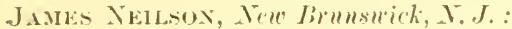

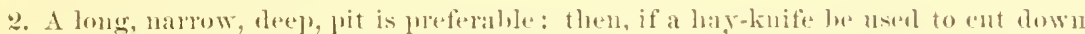
smoothly at the end. there is but little lowe forlerer exposed to the air, and conse4nently a minimmm of wasto.

3. $40 \times 14 \times 19$ feet, late muler gromul.

4. Concerete walls 1 fout thick.

5. Loove boards.

6. 400 pormels stomes jer sertuare yarel.

7. s1,320, incluting, a de+p mulertrain, which rost, perhaps, slot).

s. Corn.

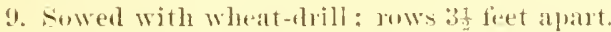

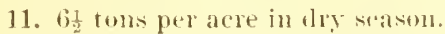

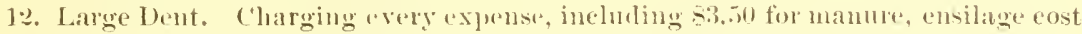
S- per ton.

21. Milk exceulingly rich in roam ant of remarkal,y pleasant tlavol.

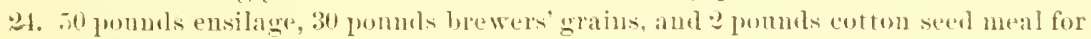
a 1,600)-pomml cow.

2.5. Cattle gaived in weight aul aplearanuep.

Nots. - I have just contracted for a new silo $40 \times 20$ feet, $x 1$ - feet deepe to cost s.j00: to be built of chestmut posts set in the gromnd :3 feet apart, with domble linime of hembek hoarels, witl tarred paper leetween. All above gromul.

Capt. Juin l'inglips, Hudson, Mass.:

1. Commectrel with eattle barn.

$\therefore .5 \times 15 \times 1$ - feet.

4. 4 feet thick: stone wall laid 11 dry at bottom: 3 feet tlick at lo feet high: the last : feet rnbble ant cement, lo inches thick: lined from to to ineles thick with cenent, hottom and sides.

5. 2-inch spruce plank 1: inches wirle; close fitting.

6. Stones; at least 100 pounds to the sinare foot.

7. 5350

¿. Corn, Hnngarian grass, ant liowen.

9. Drills :3 feet apart, cultivated with smoothing-harmw ant horse-hoe. I prepare any gromul very thoromehly.

11). When the eorn is in the mill.

11. 20 tons. The height of corn wonlel average abont 1:2 feret, sone as high as 14 feet.

12. Southern white.

14. I used a thorse-power steam rugine, and cut my ensilane inch.

15. I emploged 2 uen cutting ju firld, $2:$-horse teams to hanl from fielt, 1 man to help loat, 2 men at cutter, an engineer. and 2 nen in silo to pack.

16. Owing to inexperience it cost me ij cests per ton for filling silo, and I estimate 692 cents per ton for raising the corn. Slall do better this year.

1i. Eight weeks.

1-. Very satisfactory; the cattle tonk to it at muce.

19. I conld perceive mo deterionation.

20. My experience leals me to set a high value upou ensilage for milch cows.

21 . It not only improses the quality of milk and butter. lont increases the quantity $\mathbb{1 5}$ per cent. 
2?. Valuahle for youmg stock aud tattening cattle. All improved greatly in condition and appearance. I fomd it seellent for horses, aud my hogs ate it with a good relish. The poultry were fed with it every day with good effect.

23. fil poumds to an arerage size animal, in some eases more, and with young stock less, jer day.

24. Two rations of ensilage with a small portion of sluorts, and either entton-seed or Indian meal, and a feod of loose hay at night. Sometimes the hay was omitted and cut roots ferl in its place. The ensilage was the stand-by.

25. In mo eave was there a loss pither in weight or lealth, but rather a decider gain in all the stock.

26. I fomm it profitable. It sared me fion 35 to 40 per cent. in cost of wintering wy cattle.

\section{Gieorat: A. P'rerce, stansterd, Canada:}

1. Sbonld it posible lu in the end of barn. All the botter if a bank ban. The button of siln shomld he on level with feeding floor.

2. Oliloug, aud height greater than wioth.

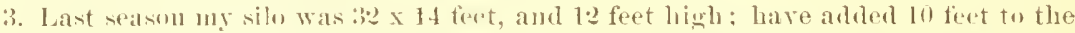
height am built another the same size. The whole "apacity is mow 1,000 toms.

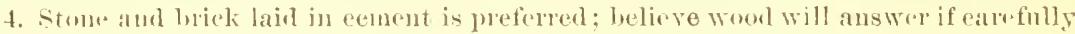
collstloteted.

i. Plankis ancose tlue silo simgly.

(i. 150 pommls of stome to the sillare font.

万. 5250

- Princopaly rolu; some elover.

9. Drills go feet apart, serel in inche's in the row.

10. Whan in the milk. Perlates more weight ean be grown by letting it stand

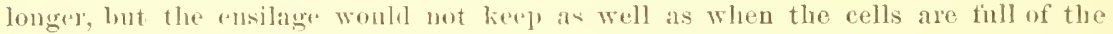
maturil juice, and not replacesl hy air.

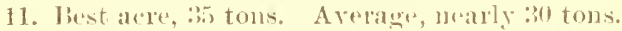

15. The cut eorn was well tomblen by uren and lorses.

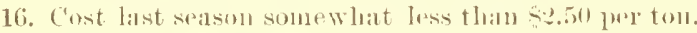

17. Was filled and closed septenther 15, and opened Jeeenher =, 1r-1.

1-. tionsl.

19. None: not more than i lumbels Ioss ont of more than 100 toms.

20. Very valnable for dairy stook, entirely taking the place of roots and largely that of loas.

21. Inmediately on fereling the ensilage the butter gained in "fuality and quantity. No fanlt was foumd by the purchaser.

22. Finl a fin strols on rusilage and they did well; calves and jommg stock did remarkibly well.

23. 60 to 50 pommls per day.

24 . With meal.

25. Very good. Ther commenced to gain as soon as they were ferl malage; formurly lad laty, routs, aud some grain.

24. A great advantage over the sistem of feeding hay and roots in winter.

Geories T. Poweli, Ghent. X. I. :

1. Silos form part ot barn: all alowe gromul, and opening into feediug-room.

3. $5 \times 11 \mathrm{x} 16$ feet, and divided into 4 ajartments.

4. Concrete.

5. 2-inch plank.

6. Press with sorews: the higher silos are made the less pressure required.

․ Cost of walls of barn inclurliug silus, - cents per cubie foot. 
8. Com and unillet.

9. Drilled and cultivated with harrow.

10. Just after hossoning.

11. 10 tons of “om, 4 tous of millet; the season being mufarorable we lat but lialf a crop.

12. I use sontlem loorst-tootl, blomut's Prolitic, and sweet coln.

13. Think sweet the hest.

14. Cut $\frac{3}{8}$ of an inch; the fine-cut forlder jeserves better.

15. Fill rapidly as possible, tramp the edlers well, and wejebt as soon as filled.

16. One silo filled with nillet, put in whole length, cost 2.; cents per ton; corn ('ut cost 50 cents per ton.

17. 3 montlis.

1s. Condition "xcellent; "xcept millet aromol ediges a little monleded.

19. The ment millet continued to moln a little after opening; con remained mchanged to the last.

20. Execllent tor milch cows.

21. A barger and fir better product than the best hay gave.

20.2. Fed 350 sheep, ewes for early lambs, wothers, and lambs for fattening. A severe alromglit bronglit my sleep np in hal condition for wintering, but they inproved steadily and came ont in good comlition fo sell, with nutavorable circumstances all throngh the feerling season.

2:3. Lows, 50 poumds per head daily; sheep, 212 to 5 pounds; horses, 20 pounds; hogs, 2 to 5 pounds.

:24. Fed ensilage morning and night with grain upon it, and hay or straw at noon.

25. All stock fed on ensilage improved in condition and appearance stealily.

26. I am keepmg four times the quantity of stock with my silos that I hare been able to keep heretofore. Its alvantages will be great in the preservation of "lover, which is often nealy rumed hy wet weather in the attempt to cure it; the same is true of millet. A silo filled with green fond in time of protratet dromght is invaluable. In Northern States wam buildings should be provided for stock; ensilage should wot he firl where it will freeze before the stock can cat it.

Jacob Puasery, Wassaic, N. T.:

1. Silos should by all meansopen directly on feeding thor.

3. $25 \times 16$ feet, 14 teet deep); six, sirle by sirle.

4. Concrete-one part cement, tive parts coarse sand, five parts suall stomes; built between planks supported by studling in such maner that the planks ean be raised after being tilled with concrete. A wedge driven lightly between studs to spring them apart, say $\frac{1}{2}$ iuch, allows the planks to slip upwarl easily and without chacking walls, which are still sott.

5. Two or three inches of straw, if eleap, will save a little ensilage at top; common hemlock boaris, laid on so they can settle with the ensilage and not biud on the walls, have proved perfectly good; uo harm is done hy their lapping anywlere that is convenient.

b. Stone, 18 inches reep, it convenient; earth would serve equally well.

7. About ficonts per cubic foot of contents, having to haul samb, cement, and lumber 3 miles.

8. Grass-Hungariau-nrass and corn.

9. I have so far preferred corn raised as for ears; cutting ears and stalks together.

10. Lrerything except corn should be cut before lun blossoming ; con has proved equally good with me when eut betore the ears were all in the milk, and when ripe enongh to harrest in ordinary mamner for pars.

11. Everything depends npon quality of soil, amount of manne used, and cultivation. Lamil that will yield a ton of Ints per aere will, of course, give 5 or 6 tous of 4 SIL 
green grass, and shoulel yield - to 10 tons of Hungarian, or 10 to 12 tons of corn ins

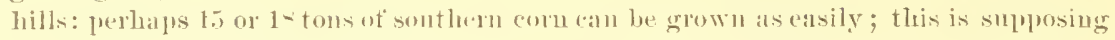
the grouml to be titirly mamminl.

14. Cut abont an inch in length; used a one-horse power. An engine would he more afficient.

15. No hatru seems to ellsme if silo is two weeks or morr in filling, provirling emsilage is woll trodiden and packed as put in. l'utting in 95 toms per day there should be

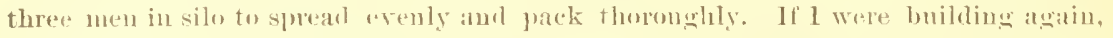
should make openings at hottom large enomele to alutit horres and tread with them, leaving then insille until siln was tilled.

11i. 泣 cents jor tom.

1\%. Tot lesi than a month.

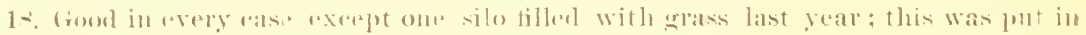

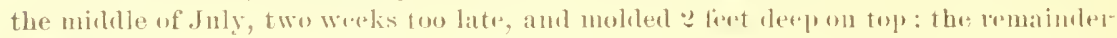
was goorl.

19. None in my experitilec.

20. Entirely satistiutury.

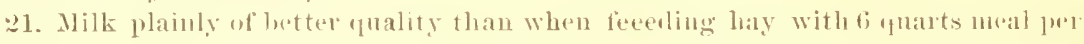
d:ay.

2.3. 60 poumels per day ; rows of small size.

24. Part of the time with 1 pomme cotfon-serel mul pel day, then with 3 pumbls. wheat bran.

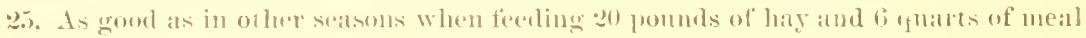
pere lay.

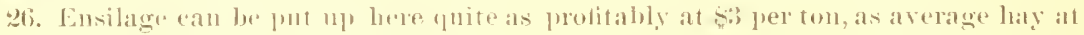

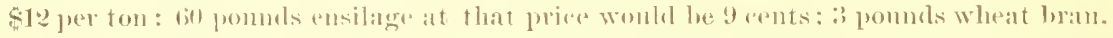

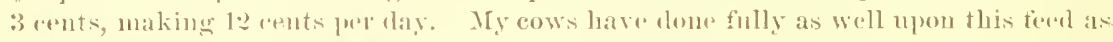

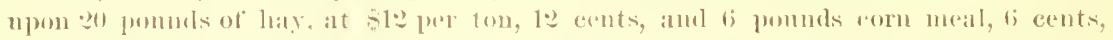

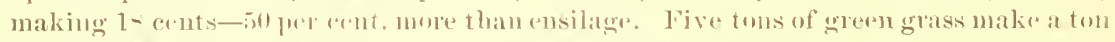

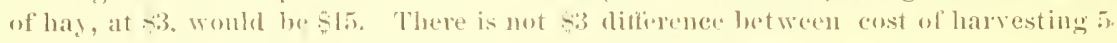
tons of assilage and 1 ol hay. In maze the showing is loetter.

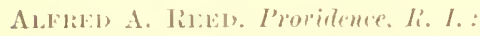

1. Silos join cow ham at rath end at riglit angle. Ensilage is comvereel from silos

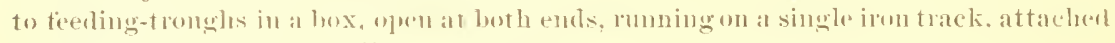
to the eciling ot batru ant silo.

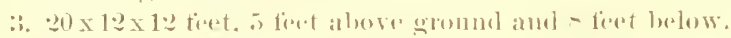

4. Stome and erment. One silo built of stone lail dry l- inches thick, faced with finclues of gront (cement and small stones) and one thin coit wi cement to make a

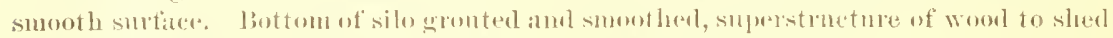
water. Secomel silo construmetel of small stomes, amol rement male thin, amel pourecl

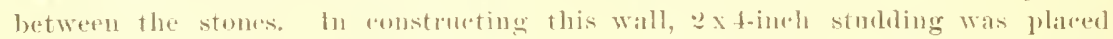

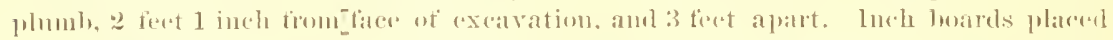
lorizontally on inner side of studeling, lotween which and tace of excavation the stomes were labl, When tompleted, the boarls and stmding were removed and thr. firce of the wall pointed with cement to make a smooth smitace. Cement mortan" nsed was in propertion of one of cement amel two of shall' sand.

$\therefore$ Two-inch plank laicl with elore joints.

(i. In one silo 1,200 pommls of stoues, packed in 21 oil barrels, erinal to 50 pommds

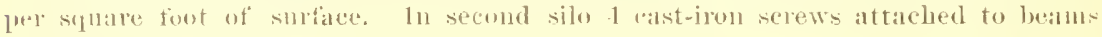
(1)

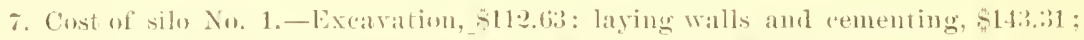

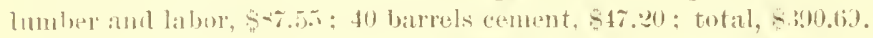

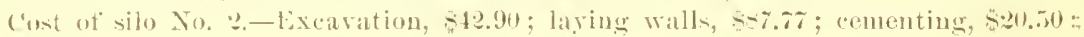




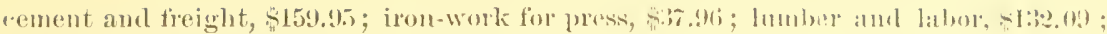
strews and firight, \$50.24; total, s531.t1.

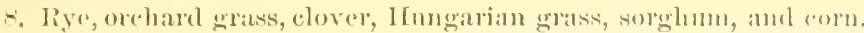

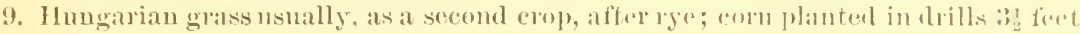
aluat ; cultisated freguently.

I0. Whan in blomm.

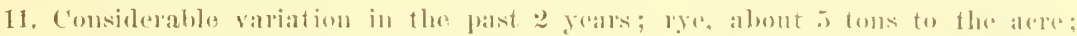

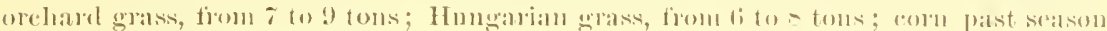
(viry dry), 1 if toms to the acre.

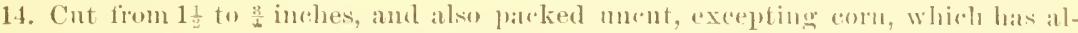

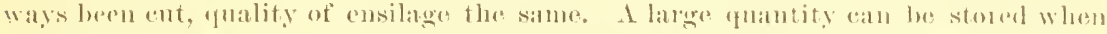

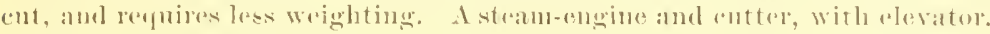

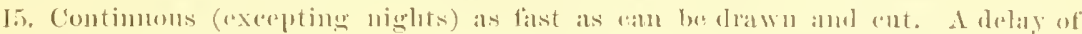
two diys in filling wili not injure it. Have eomtinnerl filling silo during a ruin withont injury to (he ensilage. While filling, the forlere is anstantly trampor ly one man, expecially aroumel the edges of the silo. Whet fillecl, or partly filled, witl one (")op?, it is rovereal at onee aml weighted.

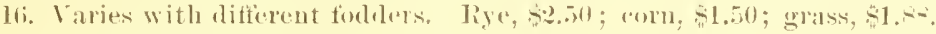

17. Eirliest time, six worlis.

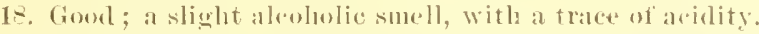

19. If surface of ensilage is exposed for one or two warks, a monld forms varying in

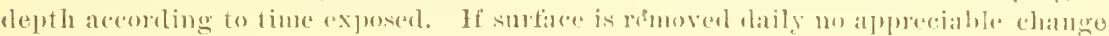
necurs.

?0. Ensilage is cheaper than hay.

I. Cows previously ford on hay give better milk when fiel on ensilage, butter nearly as high-enloned in winter as in summer when fed on gerass.

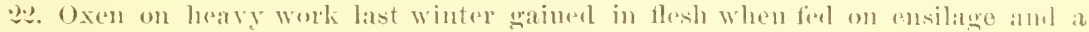

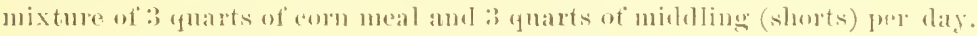

2:?. All they womld (at clean (about 50 pomnds).

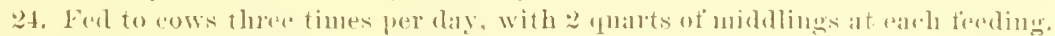

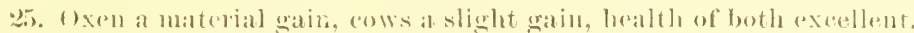

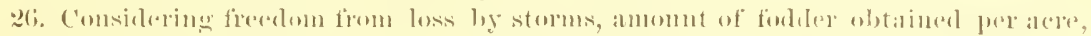

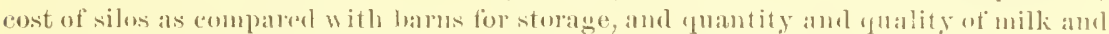

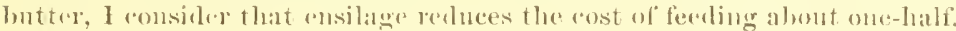

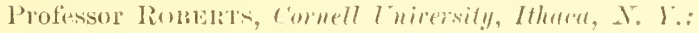

1. On sime level; about halt shoukl be muler gromul.

2. Twiere (or more) as long as witle.

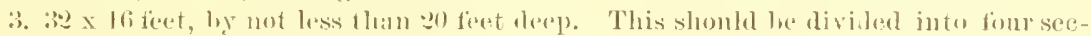

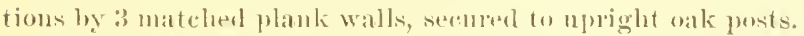

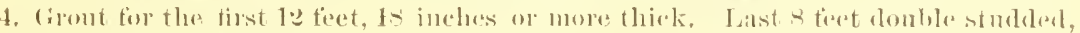
cheaply loarderl iusirls and ont.

5. of :-inch matched light wool as long as silo is boal, lise two inches: wilth of

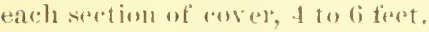

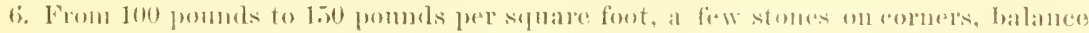

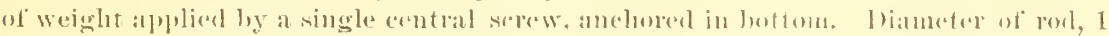
inch to I Inches for 30 toms pressille.

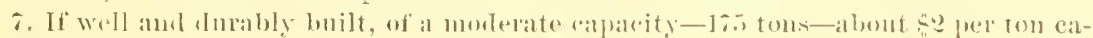
palcity.

- Rige, com, oats, grasis, roverr.

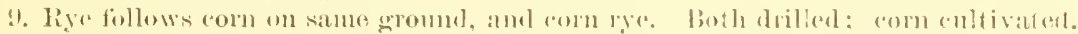

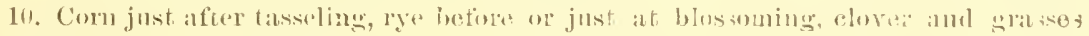
sime, wats when in the milk.

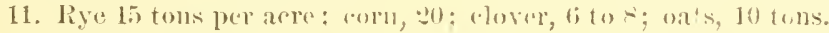

12. White Sonthern. 
13. No experience.

14. Engine; cutter with carriers; rack :5 feet loug, on trucks; fodder is drawn firm the rear of rick, about 600 to 800 pounds at a time, by the lead horses of a 4 -horse team. Two toms can thus be loaled by two men, in ten to fifteen minutes.

15. If well tranper mis be three or four days in filling.

16. 50 to 75 cents jer tom.

17. From four to six weaks.

17. Light colored and somewhat acirl; acidity largely disappears when exposed to the air for a time, ambl colm retmrns.

19. None pereptible if not loosined.

20. Very valuable for mileh cows, young cattle, horses, and fittening animals.

21. Milk solk, well likred, no complaint.

2.). See 20 .

23. 50 pounds per head.

24. Always with other forl.

25. Ciain sat isfactory, health perfuet.

26. Witl skill it is certainly profitable, especially as it enables the farmer to tirle over the hot, dry monthis.

J. B. liogrars, Binghamton, I. I:

1. Opens to feediner-allury in bispenent.

4. Wall 15 feet below sills of halu, T feet below stable floor ; stonte laid in cement except between silo and stable. Bottom and face of wall cemented. Between silo and barn abore sills the wall is of donble boarels; space filled with coal ashes.

5. 2-inch plank.

6. Stones, 7i, to 100 pommls per synare lirot. Am arranging to use iron rods and sirews.

7. Abunt sू:?(1).

$\therefore$ Corm.

1). 1)rills three fiet atpart; cultivated.

10. That was lyest which had just como into blossom.

11. Small rolop: only 10 toms prer alcle.

1\%. Stowrl's Everwarn. Mammoth Sweet, Blonnt's Prolitic, and southern White.

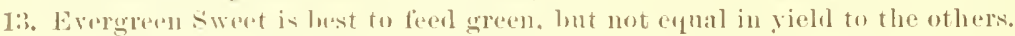

[4. Cut by hand in liell : usenl forder cutter at silo with two horse-power; cut three eightls of an ind ; shall ent there guarters of an ineh this year.

i 15. Ilad two men treal in silo; tilled in thrediys half full, whidh used all our forleler.

16. Cutting corn, lumling, paying fin machins, teans, anel men employed, si.25 fore ton. This can be redured by larger crop and hetter linowledge.

17. Two months.

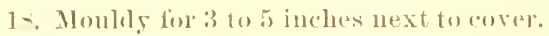

19. The weight was removed som after silo was opened, bnt cover was removed in sections as nsert. Any partexposed to alr after being opened was somewhat damaged.

20. Two tons ensilaw better than one ton of hay.

21. lucreased the tuantity abont one puart of milk por cow daily, and improved the thality.

23,24 . 25 to 30 pound per dlay in two feeds, morning and afternoon; also gave two light feeds of hay. Fel alout half as much hay as should have done withont ensilage. Hope to have ensilage enongh this year to feed 50 or 60 pounds daily, and little (1) 110 hily.

25. Iy cows gainet in tlesh and lealth, and it was remalked ly many farmers who cance to see, that they looked and stemed to fiel better than any cows in the vicinity.

2i. So profitable that l have mole than doubled the vapacity of my silos aud size of my stables, and expect to fill the stables, aud fieci o: c'msilage. 
H. G. Root, Reminglen r\%:

20 tous per aere is a large yind of rom; I weigled mine-rlid not guress. IIores

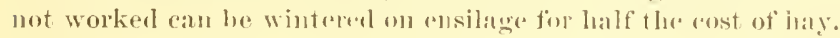

\section{E. K. SEABitri, Walpole, I. HI:}

1. In corner of ham which has a collin y feet below tho floor and y feet above;

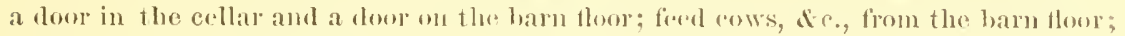
sheep and hogs from cellar.

3. $11 \times 14$ feet, 18 feet ileril?.

4. Walls below the haru flool-on two sides cellar-wall cemented: on the otlor two sides briek and rement. Above the barn floor, two thicknesses of hoirds with tarroul sheathing papes between.

5. Plank.

6. Inon rods with thrads, set in stones at the hotions; a timbur across and followers; press it with these serews instead of woights.

7. $\$ 84$.

\&. Corm.

9. In drills, 3 feot ajart.

10. Just ready to ear.

11. A sunare of the average of Sonthern corn woigherl at the rate of 36 tons to the acre; sweet-coru uot half so mmeh.

12. I like the White southern. It grows large, and in the silo I think it just as goou as subller sorts.

12. Yielel too small.

14. Cut of an inch; used a 2 horse-powar.

15. Filled in $2 \frac{1}{2}$ days.

16. Cost 90 cents a ton to ent anıl junt in.

17. Two montlis.

18. All right, except a little on the mpluer onter edges.

19. None,

21. Nakes as much and as good bntter as grass, and as much milk as the averago pasture: butter of better color amb texture than from dry foldex.

22. Tery gond for young eattle.

23. 40 pomuds per day. A common cow will eat fil or 70 pounds per day, and do well for a slort time without of her forer.

24. One fred of dry forlder. Have male several experiments, and find it is not at propere teed alone.

25. Stock did well on two fieds of ensilage and one of hay per day, with thr silme amonnt of grain I should feed with all dry fodder. Never had stock do butter.

20. I regard ensilige as a sucess. I can winter more stock at less expense than any other way I know of, and have them cone ont in the spring heavier and healthiel.

Erperiment No. 1. White eow gained 40 pomds in twenty days, wn 40 pomels of ensilage and 4 cpuarts of meal.

Experiment To. 2.-Yearling steer just out of pasture (weight 640 pounds), on 40 pounds of ensilage per day, lost 5 poumls in three werks; I then adred one quart cotton-stad meal and a very little hay, and he gained 50 pomds in two months.

Experiment No. 3.-A heifer two years old, on 40 pounds ensilatge and one quart cottom-seed meal and a little hay, made $6 \frac{8}{4}$ pommls very nies, liart, yellow buttre in a werk. On 60 pounds ensilage alome male is pounds, as goor color, but not quite as firm, in the same time, and the cost was less pre pomm. Various other experiments liave brought me to the conclusion as stated.

Sears Bros., Horcester, Matss.:

1. Adjoining barn; ensilage carried on a car to cattle.

3. $40 \times 13$ feet and 13 teet high to the sills of the building covering it. 
4. T'lue walis are 16 inches thick, made of comerete. A galle-roofed building with sills berliled in top of cement walls, increases depth of sibo s feet.

5. :-inch plank.

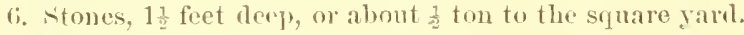

7. 8400 .

$\therefore$ ('orm.

9. Planted in rows $3 \frac{1}{2}$ feet apart, and hills 15 jneles apart in the row 4 serds in a lill.

10. We had one field just tasseled ont, one forming ears, and in one the corll was landruing when we filled the silo. Wr: found, when we eame to feer. that first fichl Was too watry and the last too dry and woody, lut the second was alout right.

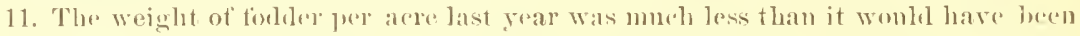

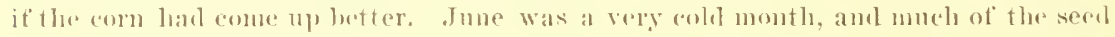

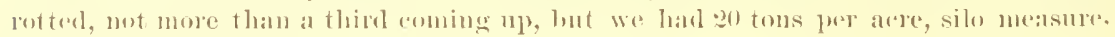
50 enlive fint pertont.

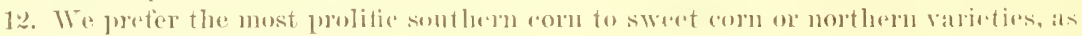
it (a)utaius much nure foliage.

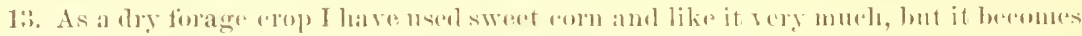

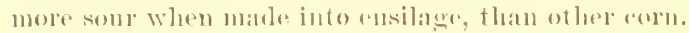

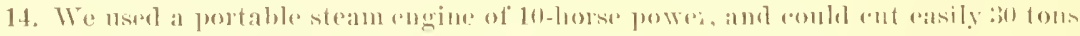
per day into sosch piones.

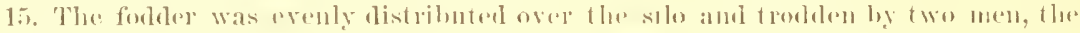

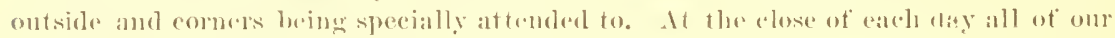
men tom about twrinty mimutes.

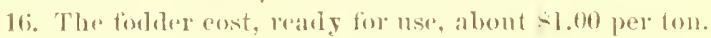

17. 'T'wo montls.

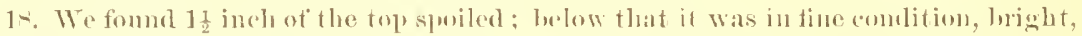
and of a pleasant acid tlavol:

10. In opening our silus we rook the stomes all off: this was a mistalie as we lost alout a ton apparently from the want of sulticient pressme to exclube the air.

2(). Our husiness is making milk for market, and we lave rxperimented to ascertain its vahe compared with the lost early ent loy. Wr tind that 1 fon of ensilage is worth from sir to so?, or :3 toms mulage are worth more than 1 ton of best hay tor 11!1 ling milk.

21. We lave hat nu cxperience in making butter or cheese, but have eaten both male firom ensilas an, and fombl them very gooml.

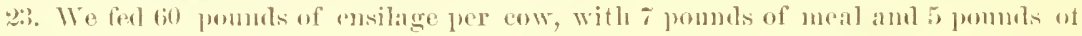
liay.

24. We feel twiee a lay halt of the ensilage and meal cach time. Onr meal wat

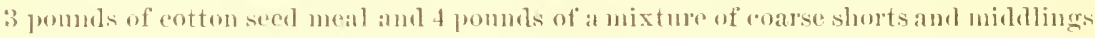
We believe that eattle thrive hest on a variety of fond.

25. On eattle were never so well as they wore the last winter; wo laal but ond. fow on the sick list, and slu only for a day. 'Tlueg gained stearlily in flexh through the winter.

26. I think feoding ensilane in American falming is yet an wxperiment; that its place in the futmo will be a very important one, I verily believe. Onr experiment

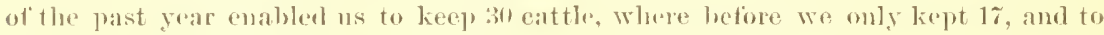
make : $: 30$ quarts per day, where hefore we only madr 130, at a cost then of $3 \frac{1}{2}$ cents jer yuart, but uow of only 2 crouts.

13. F. Silluixis, froy, Me. :

1. Toor opens from ferding roum flows.

:3. $17 \times 12, \times 14$ feret derele.

1. S-iueh brick wall. latil in cement. 


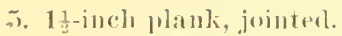

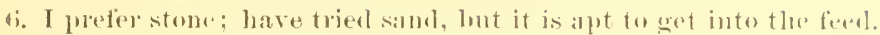

ร. $\$ 250$.

$\because$ Colm.

9. Drills; kermels, 6 to R inelus apuat.

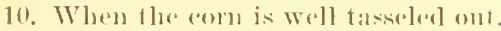

11. From 950 10:30 toms.

14. Cut one-guater inch long; cutter operated by horse-power.

15. Whild tilling silo I kept three men treating the lodkler. I think it mecessary to Drave it well trodelen.

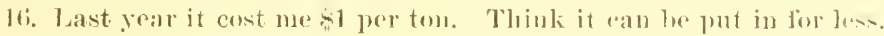

17. Three momtlis.

1\%. Excellent.

19. The first frar 1 dial womg by remoring the stone all at onde. live rumbing a thinl and cotting to the bottom, then renowing another section, there is no loss.

21. More milk; Imtter of better color, and tlaser more like Jund hutter.

2.). My stoek consists of aows amd sherely. My sheep neper did hetter.

2:3. 60 ponmels per day to eows.

24. Feed three times a ias, with 1 fuart of eottom-sorel ealh tine, ame a little hay at night.

25. My cows never were in so thriving a condition as now.

3i. It is altogether ont of my line of hmsiness to write om any subject, but I have bern ealied upon yuite often to express my opinion in regart to silos and insilage, and I am most laply to do so, for I betiere that this new method of preserving corn folkler, sc., is the thing that will help the farmers of our conutry. Am soriy that some of the lealing men of the agrienitural interests of Mirssachusetts shomlil take such a leciled stand anginst silos and ensilage.

Finsers H. Surmu, Hyattsville, Me.:

1. Separate building.

3. $12 \times 10$ feet, 12 tiest deral ; all below gromud.

4. a-inch briel, laid in cement, except woor partition from root cellar anjoining.

万. 4 inches straw, and loose boards on top.

6. 400 pounds stone per square foot.

\%. Abont $\$ 150$.

$\therefore$ Corn and rye.

9. Corn planted in drills:; feet apart; enltirated between drills three times.

111. When the ears are getting into nilk. Rye in blossom.

12. Any large, strong-growing variety.

13. No material advantage; wonld not nse it.

14. Cut by hand, and hanled to silo immediately.

15. 14-imch power eutter. Engine bired at s.5 per das; belonging to thrashingr-machine. Corn cut abont 1 incl long; trimpor thoronghly ats it is put in. Filled in one day.

17. Abont six weeks.

1尺. Perfectly free from rot or monlel: strong alooholic smell.

19. After weather becomes warm it will heat and mould soon after being exprosed to the air. The best plan is to take ont enongh for a week's use, and spreal so that the air will eirenlate throngh it, and eover the exposed silo surface with straw, or some loose material. This precantion is not nested in cold weather.

20. I see no difference, in the effects on mileh eows, from goou pasturage.

21. Excellent, both as to quantity aul quality, during the six montlis when good pasturage is not available. I shomld say 50 per eent. arrantage.

20. My horses eat it with avidity, and excollent results.

24. I mix with it a small quantity of hran and eorn meal. 
25. Both horses and cows improve in coudition over any other method I have tried, and keep in excellent health. I give the horses dry feerl once a day.

26. My impression is that ensilage from a given area of gronnd will keep at least clonble the stock, during the winter, that hay, corn fodder, or any other crop cured dry in the ordinary way will keep. Yon observe uy experiment has leejl on a very small seale. I keep two horses and two cows, and uny observations will not be valuable to large producers. Last year I used corn only, and the dronght reduced the guantity so much that my supply only filled the jit about two-thirds full, and to avoid the cliffienlty of having to throw ont the stones from so low a level, I cut has and oats in the sheaf and filled to the top loefore putting on the cover. The diy cut feerl catme ont as bright and in as good condition as when put in, and proved at rery economical method over the slow process of cutting by hand. This year I have filled the pit half full of rye, cut in blossom, and when the corn is ready shall remove the corer and fill to the topl.

\section{T. Sprague, Bramdon, Tt.:}

1. On one side of barn tloor, stable opposite.

$3.50 \times 15$ feet, 18 feet deep.

4. Stone and cement 4 leet to basement thor, brick and cement 10 feet to feeding thoor, donblematehen boards 4 feet abore thor, Bot tom and walls below floor cemented.

5. Inch boards 15 teet long, fastenerl togrether with eleats, each cover 3 feet in width.

6. Boxes 12 inches square, 18 inches deep, with hand holes near the top, each box holding 100 pounds gravel.

7. \$5:1, which is much more than necessary. Mine was the first one bnilt in this vieinity, and 1 wished to aroid a faihre.

8. Corn.

9. Sod ground well worked by harrow, rows 2 feet apart, 220 pounds of phosplate to the acre, 30 kernels to the foot, after corering phospliate with half inch of dirt.

10. When the stalk has tasseled and before any part las turned to woody fiber.

11. Nine last year averaced 31 tons per aere, estimating 50 pounds to the foot after boing pressed.

1.2. The southern white. It yields well, and is of good rublity.

13. Hore sugar in sweet corn, lut not mongh to make np for the difference in yieh.

15. One man with seoup or 6-tined fork throws fext as it comes from eutter erenly were the silo, and another treads it compactly. I fiml that if we fill one foot per day, ear.h layer protects that beneath and exchules the air from it.

16. The whole cost per ton, not reckoning interest on the land, was \$1.50). I am in hopes of lessening the cost this year 20 per cent.

1\%. Six weeks.

1-. Sweet as when put in; no signs of mould on top.

19. Not any. I took out enongh each evening for the next day, exposing it to the ain that it might turn slightly acid, thinking it hetter for the animals.

:0. Equal to gresen corn or grasis.

21. Increases thow of milk from 10 to 15 prer cent.

23. 1 feed cows 18 ponds tbrec times daily, alling 10 poumls when in new milk; two-year ohls 12 pounds; yearlings 10 ponmds.

24. Cows $1 \frac{1}{2}$ pints cornmeal per lay, and proportionately less to sonng stoek.

2.). My eattle looked better and folt more playtul on ensilage than when ferl on the best of dry fodder. They drank lut little water during the winter. The excrement was in the sane condition as when on pastmre, denoting that the system was in a healthy conditiuls.

26. It is a good grass crop that will yield $2 \frac{1}{2}$ tons of hay per acre; this would all be required here, with six months' freding, to winter one cow; is tons of ensilage winteris the same auimal in a better condition : but with 30 tons per acre an acre of land will winter six cows and produce 1" per cent. more milk. 
Aloxzo Stebrixs, Ternon, Tt.:

1. Located 50 feet from feeding-room.

3. $40 \times 12 \times 15$ feet deep (10 feet bolow surtiace of gromal).

4. Concrete 17 inches thick below the surface, and $1 \cdot 2$ inches thick alure gromm, cemented so the sicles were pertectly even.

5. Covered the ensilage with thin layer of hay, then put on 2-inch plank and covered the plank with about 2 inthes of heavy loan.

(i. 1,500 pombls stome to the sinare yard.

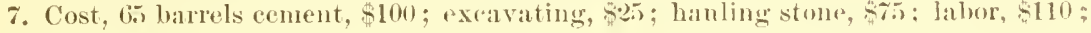
whole cost, $\$ 310$.

8. Corn.

9. Planted in drills, $3 \frac{1}{2}$ feet apart; cultivatul the same as other firld corn.

11. 22 tons jer acle.

14. Cut and draw inmerliately to cutter, which is mo ly 4-horse engine. Cut onehalf inch long, and carriel to center of silo by means of carrier attacherl to cutter.

15. As fast as deposited in the silo spreal and tread down hy a loprise 4 quarts salt to ton.

16. Cost, $\$ 1.45$ per ton.

17. Finisher filling midule September: opencal Novenber :

18. Good.

19. No deterioration.

20. Cows thrived well, increasing in thesh.

21. Quality and quantity of milk and hutter equal to that protucen from the best. Jure pasture.

22. Joung stock tlirived well.

23. Fel an average of 60 pounds per eow.

24. Fed cows 4 ynarts cob meal and same of wheat bran per ray, mixed with ensilage.

25. Gained in flesh and were healthy.

26. Am perfectly satistied with the experiment, and shall rontinue to nse ensilago.

My cutter was not large or strong enongh; have now purchasenl another, wifl carrier, which I expect will greatly realuce the cost of filling the silo.

\section{W. C. Strong, Brighton, Mass.:}

As my trial of ensilage is somewhat exeptional, I will omit answers to the questions, and ouly state a fow fiucts which may be of pulblie interest. Haring a remented tank which had been used as a reservoir for water, f tried the experiment of using it as a silo in 1880. Ten acres of Hungarian grass (abont 130 tous), wry foul witl pig and rag-weed, so that it would lave been nnmerchantable in a dry state, was rut fine and packed in the usual way, and sold dnring the winter to milkmen at so jer ton, they doing the carting. They reportel that the cows songht the ensilage with avinlity, ate it clean, and seemerl to thrive and give an improverl puality of milk over that prodnced from hay and browers' grains. Last season the silowas filled witl corn of excellent quality, and the bulk of it sold to milkmen at for per ton, they coming for it, in loals of 1,500 to 2,000 pounds, ahout once a week. The reports have heen emplatic from purehasers that it was an economical aud excellent fodeler, the yuality of the milk exciting the notice of comsmmos as more like June milk thin they lial ever had before. A smaller allowance of hay and brewers grains was used with the ensilage. I fed my own cows from a silo at my home farn, aml made. Jum- bntter in Jannary-is new era in my experience. That ensilage of corn is the cheapest and nost wholesome food for mileh cows, if supplemented with a small alluwance of shorts amd hay, B entertain no donlst. 
Capt. A. II. Swexey, Hest Troy, N. T.:

1. My silos are away from freding-rooms; they shomld open into them.

3. $36 \times 12$ feet; 12 fiet loep each: two nnler one roof. 'This size is better than larger onus.

4. Stmme. laid in mortar and cement.

6. Alout 20 tons to earlo slo: of lyarrels filled with sinul and stomes.

7. Cost sionol.

$\therefore$ Corm, rye, and rlover.

4. Corn planted in rows, one bashel to the acre.

111. When the most juier is in, for cows and pigs. For horses, colts, amd brood mares, I prefer it a littlerijer.

11. From 15 to 60 toms of eorn to the acre; to 10 toms of rese

1.2. Southeru White for strong clay land.

13. Sweet corn for sandy loams.

15. Filled all we eonld each day ; rye about 4 fort, cut in 1 -inele lengtles; corn abont $\Rightarrow$ feet, cnt vory fine. Three-eighths inch I think best.

16. About sl perton, including putting in field ; cost s.2.10, including interest on lami, enltivation ame everything.

1\%. Two nontls.

1. Splendir, with slight smell like somr-mash whisky.

19. Nome whaterar, provided yon keep woights on what you aro not feeding.

211. No feed retual to it in any way.

21. Increase: no other effect.

20. Fed all my broul malrs and eolts last season with perfect succes; never gave a particle of lay as long as the ensilage lasted-three montlis.

$2:$. Gave horses 40 pommls of ensilage and 4 pommls fine feed, which is more than enongh.

24. Some I gave nothing but ensilage, 50 pounds daily: they alid well, but did 4)etter with 40 ponmls ensilage and 4 ponmds fine feed.

25. Too fat, if anything; in sulendid eondition and vely healthy.

?6. J'rofit is very large, consider my two silos worth $\$ 10,000$ : would rather pay intorest on that than give them wp.

Di. W. H. Taxier, Masair. N. Y.:

1. Silo direetly back of hasement and openinse to it.

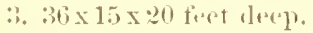

4. Comerete.

‥ 2.-inch plank, well titterl.

1. Stomas; about 1-inches dere.

7. About 10 cents a culic fout of masony. Wall 12 inches thick at buttom, 10 inches at top, slopera outsicte.

- Corm.

9. Plant in rows, fext apart, about 4 grains to the foot.

10. When the bottom leaves leegin to tnrm yellow.

11. 15 to 25 toms.

12. Tilount's Prolitic or Somthern White.

14. I nse a enter driven by an B-horse powel engine and ent the fodder about $\frac{1}{2}$ incli long.

15. The ensilane arops from cutter to the eenter uf silo.

16. Cost of entting in field, drawing, cutting, aud packing about so ceuts per ton.

17. Any time after a month.

1. Condition when opened good, with a slight aejd taste.

19. No deterination atter opening.

20. Two ponnds epral to one jonnd of the best hay for cows. 


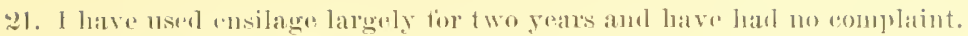

t3.). Value about mo-lialf that of liay for all stoek.

2:). A goul strong eow wants about sol pumbls a day.

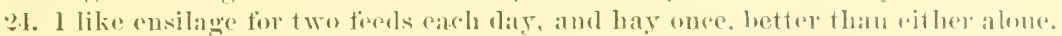

2.). Comdition of stoek good ; a very liealthy nutritions food.

26. Eusilage 1 believe to be the dairyman's anchor, on the expensive lants of the list; I would as soon think of doing without a ham as without a silo: l farm fiov profit, not for pleasure, and have fomud a silo by fir the best investment l erre made.

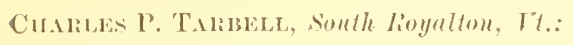

1. 20 feet distant.

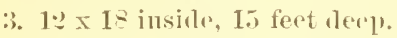

4. 10 feet of stomewall, then a sill and simls if feet to plate, shrutlect, flush with wall.

5. $1 \frac{1}{4}$-incli boards, 11 leet 10 ineles long.

(i. Stune, 75 poumls to stuare foot.

ร. 5100 .

- Corm alone ]ast year; am now growing corn. aats, and Hungarian glaks.

9. Corn in drilk: should be dressed with smoothing hamow at tirst; later, with lorese how or "ultivator.

10. Just bofore the are is fully grown, to make sure it is full of juice.

11. 40 tons; estimaterl.

13. Cannot give compalative value. Think it much rivher in sugar and stareh.

14. Corn eut last year tive-eighths inclı: shoula be ent shorter, say thro-tenths inelı; cut in the field hỵ hamel.

15. 'The ensilage should he thoroughly packed-if' convenient, with a horse-ind the whole work done and weights put on withont unuecesury delay.

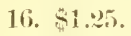

17. Mine hat fully selt led in two weeks, and might have hecn openerl withont hurt. I left it ten weeks.

18. Fresh and chan; m mupleasant smell or taste, excepting tlat iu spots, "wing fo meren filling, it was somewhit monldy.

19. No change.

22. Fully equal to goorl liạ.

2:3. Thiee large cows were forl thre full hushels per day each; a two-year ohl heilir. 2 linshels per day.

24. I think it profitalble to fund grain witl ensilage.

9.5. All the stuck, "xopt colts, gained in tlesh on ensilage alour. Their health wats perfect. The rows did musmally well in ralving.

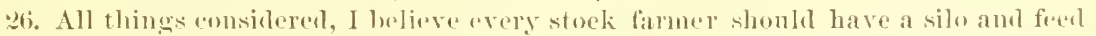
ensilage. I have mo dould of the sneess of the system. Beef and lmiter can lo marle. mueh eheaper liom ensilage than from hay.

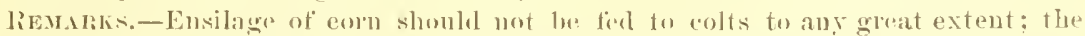
pesult will not be satisfiretory. The walls of silo should be plumb and sumoth, anl, howerer emstrueted, it is mull bettri to make it warm, so ensilage will mot hecome" fiosted. Ms experience is that stock kept wholly on ensilage, in colul weathur, drink no water and require nome. I lo not think the first ent of grass shombl be ensilagul muless the weatler is very bial.

\section{A. T. Thumas, Fraklin Park, I.,. :}

1. Door at bottom of silo opening to feeding passage. Small aar used to fual witl ensilage and run in front of eows.

2. Silo all alove gromul and was one end of a lay barn, new timbers being thown across barn to constitute one siele of silo, the other there sides heing sioles and "mol of 
barn. I should build above the surfare, on level gromul. It is easien to gaet ont the ensibuge from above eromel than to pull it out of a pit, and the carrier will just as wall put it $1 \mathrm{p} 12$ or 16 feet, when securing the erol, as to drop it in a hole.

:3. $10 \times 1$ - $\mathrm{x} 16$ feet.

4. Upight 2 inch plank nailed to girths of barn, the plank coal-tarred, building paper put on, and l-inch boards nailed on, to break joints with plank, and the boards coaltarred. No barl taste impurted to ensilage by the tar.

5. Inch boards donbled.

6. Stone, alont one-half ton to the square yard : shall put on one ton this fall. The greater the pressure the more perfoct the preservation.

7. Had to plant leavy timbers at two sides of silo, and tio them tourather to keep siln from bulging; cost, including tomr extra iron rods and extra timbers, fl14.

$\therefore$ Corn and sorermm.

9. Broadeast and in rows, the latter enltivated will smoothing hatrow mutil too large, and finished with plew.

11. Seven tons; severe dromght one humbed and righteen days withont rain to wet two inches.

12. Think Sonthern white corn of large growth, which will not rigen in this latitulde, best.

13. Sorghum and sweet corn well prestrved, but too much acid, arising, no donbt, from excess of smyar.

16. 70 per crent. per ton.

1\%. Filled September 7. "1prend November 5.

1:- A littie brown in color ; taste, a nild acil. Stock very lond of it.

19. Not any.

20. Cows dirl well.

:1. Milk of good quality, and quantity liberal.

2:. A Iolstein heifer, thin in thesh, was fed ensilage exelusively for two months, and gained stearily.

23. 50 poumrls.

?. Shall feed a little meal and drystalks this winter.

25. Cattle kept woll: lealth purfect.

oti. It pays well.

A.1Rux S. 'T110M1'sox, Maymurd, Mass. :

1. Lol feet from the barm, with a track from the silo to the barn.

$\therefore .36 \times 15 \times 16$ liest deepl.

4. Stome and concrete.

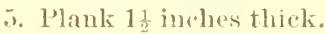

ri. Stome, estimated trents toms.

7. As I was very partienlar abont it, the digging and all, inchuling frame lunilling orex silo, cost 5000 .

$\therefore$ Corn.

9. Eighteen loans of barn manne to the acre, planted in drils $3 \frac{1}{2}$ lest apart; rm a (ultivator through it twice.

111. When the tars begin to form.

11. Arerage a little over 25 toms.

1:. Soutlern cornt is the best.

1.1. A portable engine and lange cutter.

15. Cut in pieces $\frac{1}{2}$ inch long; very important to keru it level and trear thoronghly.

16. 85 cents to 51 .

1\%. Eight weeks.

1-. It was gowl and bright, a very little acid at first.

19. Not any.

20). Cows whe in better comlition than whon fed on all hay. 
21. 'The milk is richre and better, and more of it.

22.). Fatted 11 learl and never had any gain so fast on other ford. Fed it also to shoats, and they thrive well.

2:3. 40 to 45 jommds.

24. Fed twice a day, morning and night, with a feed of hay in the formoon and one in the aftrinonil.

2.. I nover lial stork wain better, or in hetter health.

26. Saved me 25 toms of hay, and the cattle dicl better than when fed hay only.

\section{A. 1I. THomisox a Sox, Woodritle, Mass.:}

1. Ontside of barn connected with feeding-rooms.

2. $30 \times 12$ feet, 13 feet high, one-half muler gromul.

4. Concrete, 15 inches thick.

6. Stone, 100 prounds to the square toot.

7. $\$ 300$.

8. Corn.

9. Rows 4 fiet apart, hills 1 inches in the row, 4 stalks to lyill.

10. When corn is noarly in ailk.

11. 10 to 30 tons.

12. Sonthern grows largest.

14. Cnt three-eights of an inch long, with forlder cutter and portable engine.

15. Well trodden while filling.

16. One dollar.

17. Ten weeks.

18. Slightly acirl.

19. Do not see any clianges.

20. Better than dry feed.

2L. No bad effects; milk promommeed good.

2.2. Good for youmg stock.

23. 60 poumls for full-grown animals.

24. Cottonseed meal twice a day.

25. Condition good, gain in woight, health good.

26. A farmer can keep more stock than with grass and bay. Have fed ensilage two years. Shall continne to use it.

\section{S. N. Tinompsox, Southborough, Mass.:}

1. Under barn, extenling up and opening into driveway in front of cattle.

3. $21 \times 11$ fieet, 18 feet leep.

4. Concrete 15 inches thick up to tlool of driveway (9 feet) and matehed boards above (9 feet).

5. 2-inch plank.

6. Stones to the deptlo of 15 inches.

$\therefore$ \$ $75 \mathrm{or} \$-0$. I used a part of my barn cellar, therefore had no excavating.

8. Coll1.

9. Planted in drills 10 or 12 kernels to the foot, (abont four tiuses ton thick).

10. When the kernels are in the milk.

11. My crop was light ( 2 t tons per acre) on account of planting too thick; a fow acres planted about 3 kernels to the foot yielded one-half more.

13. I have not tried sweet corn for ensilage; for freding green from the field I consider it worth one-thirl more than of her rarieties.

14. Cut by steam power thee-fonrthis inches long.

15. Prefer to fill the whole in two or three days.

16. Cost of entting in fiehl, carting, preparing, and putting into silo si per tou. 
1\%. 7 weeks.

13. Good, being but slightly ardid, with a pleasant smell.

19. But little change while fereling.

20. I consider it worth two-fittles as much as the hest hay.

21 . Increased the thow of milk 23 per rent. and (fuantity of butter fully as much ;

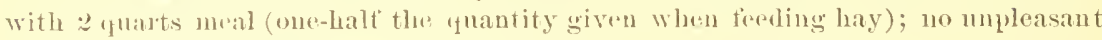
Havor in milk or butter.

20. I fiel to horses, eows, and young stuck; all showrd dreided improvenent except the holses.

$2: 3.50$ pounds per day to mileh rows.

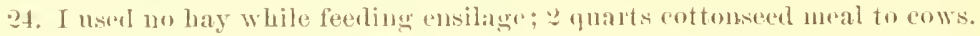

25. A decisted gain in weiglit and inpurement in appearanos.

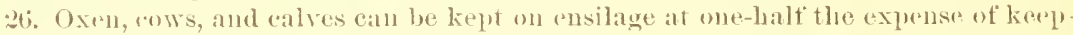
ing them in the sane conclition on hay. Not as desirable fur horses.

\section{P'. 'Tr('s, Hope, Ho:}

1. My silo is o rouls trou feeding romms; shonld be as nean as possible.

$\therefore .18 \times 24 \times 10$ teet deeple.

4. I nsed the cellar of an mucenpied buithing, romenting the walls and buttom.

(i. Stome, 40 to st pounds to sefuare foot.

7. .00 .

$\therefore$ ('oru and rowirl.

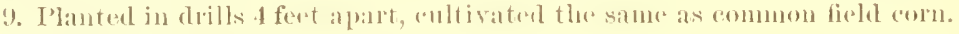

10. When in blussom.

11. 1 to tous.

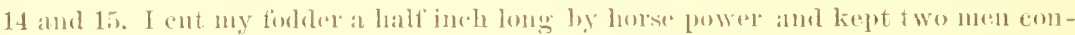
stautly irampinge it down.

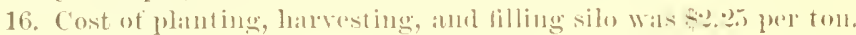

17.2 ! luonthis.

15. It was in a guend state of preservation. The rowen and leaves of the eorn harl changed to a light bown, the stallis light groen. It had an alcoholic odor and taste near the top, lont bowal down it was swert.

19. Not ally,

21. My cows give a latger tlow of milk fod on ensilage than on hay, with same amomt of grain. I do not see that it atfiets the quality either way very much.

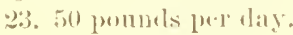

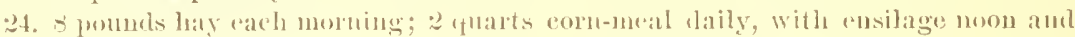
ujeght.

25. They har gool health, held their thesh, but did not gain.

:6. Very protitable at the present prices of hay.

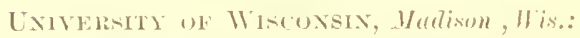

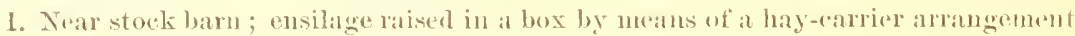
to a car which carries it to stur. la baru.

3. $25 \times 12 \times 15$ feet deep, with : feet curlong around the topl.

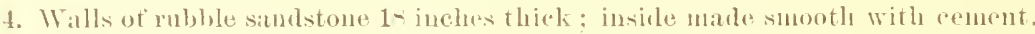

5. 2-inch plank rumbing crosswise.

i. 11: pounds of bowlders per square foot.

7. . 113.42 , includiug smperstruture costing $\$ 119.40$.

$\therefore$ Corll.

9. We drill and cultivate as common cern.

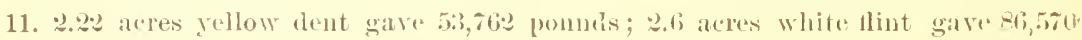

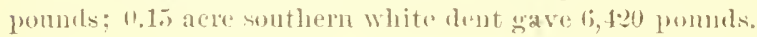


15. Filled silo slowly hecanse of jour marhinery.

11. Total cost for 75 toms $\$$ \$. (is per toll.

1\%. : $1110 \mathrm{mtl}$ is.

1-. Coorl, exrejet a firw inelues at top.

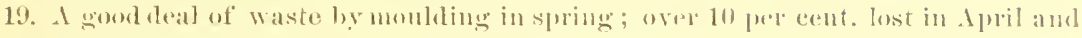
May in this way.

20. For leasme which I cambot give leere, we latve no aremate results on this point.

2.2. Calves and strets on trials of remilage alone showed a small garin whon ted all

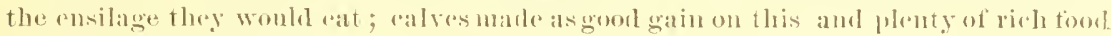
as with hay ausl rieh tood.

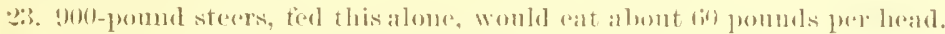

24. Fed both with and withont other looml.

25. comblition of sturk was tiul at least.

26. May pay well at bast, lont doulot it for Wiseonsin, where tha promluet is buttor and eheese; near our citiss, fir milkmn, it may pay. With a grom season [ think we can show the valne of ensilage, its cost, de., in a satisfactory manur on our farm this year.

\section{WT. N1. Vis.as, Burlington, Irt.:}

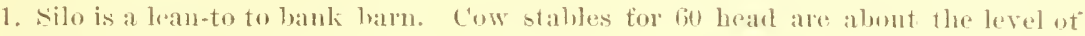
buttomu ot silu.

3. $40 \times 25 \times 25$ deet dreep.

4. Wall on hank end ?2) feet high and 3 fret thick. Is partially walled on two sides

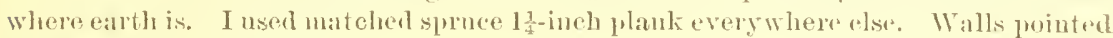
and plastered with rement.

5. Plank or hoards (romgli).

i. Stome, 1:2 to 18 inches derp.

$\therefore$ Corn.

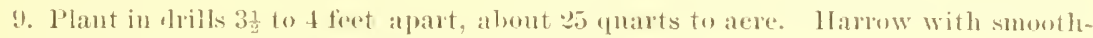
ing harrow until 10 to 1:2 inclu's high, thu'l cultivate.

11. Alont 10 to 15 tous ; say 12 for an average.

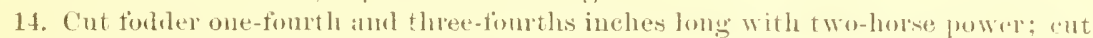
very littlo one-fometh inch: ton slow work.

15. It is important to have firdder spmear evenly and well packerl als it is put in. is inches to a foot in dejeth put in call day will do.

1\%. Abont two months.

18. Ensilage was in good condition; hat a swoet, homeg smell.

19. Whare the ensilage has been ent down and stands thee or lour weeks it will monk 2 or 3 inches into the fodder; but the cows eat it. It will lieeze solid in rory cold weather for $\geqslant$ or $; 3$ inches into the wall of ensilage, but thaws as sorn as it is a little warmer without injuring the ensilage.

*0. Eusilage is better than anything else, in my experience, to winter cows on, and ferhaps to smmuer them; but that remains to be tried.

21. Fod conilage from midile of November mutil ahout the 10th of April. lu a day ol two after, my men eomplained that the cows were not giving rnomgh milk for the constomers, so f had them somble amd then triple, the guantity of grain but we were not able to keep up the flow of milk.

2.?. 111 my stock were eager to rat ensilage.

2:3. From solo to il pomits.

24. Ilave ferl ensilage once a day with form 4 to 6 quarts bran, and hay twine; shall feed ensilage twiee and hay ones when I latre rnongh.

55. Stock never looked as well; 55 per cent. could hase bean sold for beef (had no. grain but luan); nost of then were milked all winter. 
26. Whatever is grown for ensilage should be near silo; is too heave to han a long distance. Will paty better on a large than a small scale. Silo I used last year only held about 160 tons. I have culargerl this year to about 500 tons.

Willian D. Wamex, White Plains, N. F:

1. As eomvenient as cirenustances will armit.

3. $24 \times 12 \times 12$ feet deepe

4. Wowd, as wood affords less moistur than stone or lrick. (This is for silos under gronnd.)

5. Thin lityer of rye straw and o-inch planks. Careshonld be taken that the planks are not so long as to mho on the sides in settling.

6. Anything most convenient, stone, boxes of samb, barrels, $\mathrm{f} c$. One ton of weight to 10 tons of fieed I have tomm sufticient.

7. All depenels on the cost of labor and lumber. I build them for 100 toms at at cost of $\$ 50$.

2. (eim)

!. Plant in "liedges" with grain drill, 6 inches between "liedges," and 30 inches between rows, Cultivate with horse loe.

10. When the as is fairly formerl.

11. From 10 to 40 tons; all depenels on soil and contivation.

I:. I prefer White sonthern.

13. No atl vantage over common field corn.

14. Any machinery that will ent the orn into one-half or three-inarter-ineh pieses.

15. Kerep the ent corn evenly spread in silo and well trodten aloug the edge in conrse of filling; the mildle portion will natmrally gret plenty of treading.

16. Deprents on circumstanes. I have gool, easily workefl corn gronul, and can put in for s1.50 prer tom (lalor and material ouls).

17. Thirty dars: forty or tifty abont the rule.

1-. Slight acid taste and odor.

19. None.

20) Valuable, if uot carried to axtremes.

21. If properly noed will inemase puality and puantity.

2.2. Same as for cows.

23. 3il to 40 pomids per dis.

2.4. Witls other foot.

25. Gool as to health and weight it fied properly.

$\because 26$. The eheapest feed a tinmer cin produce.

L. W. WeEks, Oronomorer, His.:

1. Feeling rooms at the ent of silus; doors opening into siles.

3. Two silos side by sille, ach $30 \times 12 \times 17$ teet derjp.

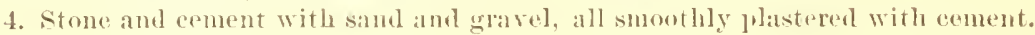

5. : :-inch pliank.

6. Stone, Tor pounds to struare foot.

7. Cost of the silos, inelnding suprestructure, \$550.

$\therefore$ Corn and rye.

9. I plant corn in drills 3 feet 6 inches alpart, ahont 3 pecks to the acre, and cnltivate thoronghly with harrow and cultivator.

10. Cnt when tar's are in silk and pollen from tassels falls freely.

11. I5 to 30 tons, depenting on condition and fertility of land, cultivation, and seasenl.

1:. Sonthern White Dent.

14. Cut by hand, placed on dunp carts, and dropped in front of eutter. I nse a 2-horse power, and cut from 30 to 40 tons in 10 honrs, $\frac{3}{3}$-inch long. 
15. I use about twelve men, two in silo to distribute and tramp next to wall, and a boy with a horse to tramp the middle.

16. From 60 to so cents per ton, depending wholly on price of labor.

17. I have openel after 30 days, but prefer 60 days, that it may be wholly cooled off

13. Always bright, sweet, and good; sometimes a half inch or so decayed on top, lont this, if mixed in, is eaten.

19. Now whatever.

$20,: 1$. Good eusilage prolures more and better milk and cream, if ferl in commectiou with a proper albuminoid ration, than I have ever been ahle to get from any othur food. No lutter butter can he mado with aus feed I kuow of, exeept sweet, yomgr grass.

2:. I have only fed cows, calves, and young stock, and I hitvo fod, when I condel, once at miderlay of hay or other dry feed.

2:3. According to weight of animal ; a cow of 900 or 1,000 pomuds, 65 to 70 pommds, if fed on exsilage alowe.

24. I talie off two or three plank next stable end of silo, cut with hay knife, and pass it ont in baskets until the loor is reached; that is removerl and the ensilage taken with a ten-tined fork and. thrown into a barrow, whieh is wheled in front of stable. I feed mileh cows from 40 to 50 pounds at two teedings, morning and night. mixed with : poumds corn meal dach feed, and same weight of some nitrogenoms food, as oat meal, barley meal, or mill feed. At noon I feed hay, oats in straw chatfed, or harley straw cliafied.

25. Stock always ganing in condition, coming wnt in spring in high flesh, aur healthy. Since feeding ensilage I have had no trouble with garget or ether mulealthy condition of nduler.

26. In my experience ensilage has proverl a gain in protit of eretainly 40 per cent. over any methoul of dry feeding that I know, lesides enabling one to earry three times the anomut of stock possible on same amomnt of land with dry feeding.

\section{Cimalifes E. West, Mallon, Mass.:}

1. In barn rellar, near cattle stauchions.

3. $16 \times 9 \frac{1}{2} \times$ feet deep.

4. Stone and conerete for 6 feet, halance of wood.

5. Plank.

6. Stomes, say IP: jounds to sifuare foot.

7. Adding value of stone and sand on hand, the total expense was about \$100. I used 16 barrels of cement.

8. Corn, llungarian grass, anl elover.

10. Corn, when beginning to ear.

12, 13. Everumeen sweet-corn.

14. Cutting-machine, ran by horse-power.

15. Cut hall-inch.

16. \$2.50 per ton; another year I eonld be prepared to do it cheaper. I small silo costs more per tou than a large one.

17. T'en weeks.

15. The layer of clover and weeds thown on top were all spoilexl. Next, the ITungarian grass, which has a strong tembleuty to ferment quickly, was rotted aroumd the sides of silo, edges of the plank, and in contact with the clover. The balance was good. My coru-forder, except on sides of silo, was in good condition. This season, I shall allow a little more play between the eurls of the plank and sides of the silo, and place a narrow strip, lengthwise the silo, on top of the plank's enel, to act as a follower, ancl exclule the air. I threw in some large sugar-berets; tley came ont shrunken one-lialf in size, and well pickled.

20. My milch cows were very fond of the ensilage. I have some left in the silo 
at this clate, July 15; they will leave green grass and eat the ensilaye, sceming to prefer it.

21. I think, when past a certain stage of fermentation, although relished by cows, it has a tendeney to dlavor milk and butter like cabbage.

23, 24. 2 bushels a day, with 3 quarts shorts, and one feed of dry hay.

26. Profitable in conomy of labor, room for storage, and saving food.

\section{JNo. I. Whituan, Dallas Centre, Iowa:}

1. In the center of a circular baru, with two rows of cows arranged outside.

2. Octagonal.

3. 22 feet across, (four sides 13 fect, four of nearly 8 feet;) depth, 20 feet; eapracity, 200 tous.

4. Conerete.

5. 'z-inch plank.

6. Gravel in boxes, 100 pounds to the foot surface.

7. Cost, $\$ 250$, roof not included.

8. Corn.

9. In drills; about 5 kermels to the foot.

11. Corn as soon as the ear is in the milk; millet when in bloom.

11. 15 to 30 tons.

12. Sweet corn of the large variets.

13. Have tried only fielel corn.

15. The silo is 12 feet above the floor: the feed is earried by a 32 -foot elevator from the entter,

16. Cost last year 60 eents ger ton. I hope to reduce the cost this year.

17. Nearly :2 montlis.

18. Sweet and grod, "xecpt a fraction of the top immediately under the planks.

19. Some, when exposed to the atmosphere.

20. Fully equal to half its weight in hay.

21. Very similar to that of green grass.

2:2. Same as No. 20 ; rxtral good for ealves.

23,24 . If on full feed, 50 pounds per dis; a less amount with some grain and hay is better.

25,20 . Mr experience is yet too limited to determine.

\section{Artemas WuLner, Maynard, Mass.:}

3. $40 \times 16 \times 16$ feet decp.

4. Stone and concrete, facel with eement.

6. Stone, 200 pounds to the sipuare foot.

7. \$600, including roof, \&r.

8. Corn.

9. I plant $3 \frac{1}{2}$ feet apart, and cultivate with a horse hoe.

10. When the ears begin to form.

11. $2: 2$ or $: 23$ tous.

14. I cut some five-eighth inch, some three-eighth inch, and see little or no differenee in the eusilage.

16. 75 cents per ton.

17. Two months.

18. 1t opeued well; was sweet.

19. The cattle ateit as well 1 , to June as when it was first ojened. I did not notico aшy great chauge.

20, I lo not think it quite as gool as Englisl bay for milch cows, but lutter than common stock has. 
21. The milk sells well; no fault found with it.

22. Calves and young stock did well on it, with very little grain.

24. Ensilage alone to dry eattle, but to mileh eows hay and grain every day.

25. Stock fed on ensilage kept in good health, and looked well in the spring.

26. There is great profit in it. I ean keep double the stoek on the same farm. I should not want to he withont a silo.

George W. White, No. 349 Canal strect, New Fork City:

1. On basement floor, but not unkler ground.

3. $18 \times 22$ feet; 20 feet deep.

4. IValls of matched hemloek boards with three-ply roofing felt between; timbers 3 - $\mathrm{x} 10$ inches, running horizontally; the lower six being 12 inehes from center to center; then increasing in space 1 ineh nutil the top is reached. There is a row of doors, one for each division between the timbers.

5. Boards, 1 ineh thick.

6. Sand; 500 pounds to square yard.

8. Corn aul millet.

9. Corn planted in drills; millet broadeast.

10. When the ear is in the milk.

12. Sweet eorn.

13. One-third more valuable.

14. Cut into three-ineh lengths at top of silo, with gang of saws rumning np and down; saws 3 feet long, gang 12 feet wide. The fodder is clrawn from the field and discharged upon an endless apron, the movement of which earries it throngh the saws.

16. Estimated at 56 eents per ton.

17. Eight weeks.

18. Good.

19. None.

20. Nothiug superior to it.

21. Gioorl.

23. 60 pounds per day.

24. Mixed with grain.

25. Inproved eoudition in every respeet.

26. Most economical methoul of storing heavy crops; it insures safety.

\section{Whlad W. White, Canaseraga, I. I. :}

1. silo in and under barn.

4. Stone and eement.

6. Stone, 1 foot to 18 inches in depth.

7. Cost of a eellar with roof.

8. Com.

9. Drill and enltivate, :8-inch rows.

10. In flower.

11. 10 tons-possibly 15 tons.

12. Southern White.

16. $: 30$ to 50 cents.

17. Three months.

18. Perfect; slightly acid.

19. None.

20. Good as June pasture.

21. Adrs one-third or more.

22. Equal to grass. 
23. 30 to 100 pounds per das.

24. Both ways.

25. Improve in both.

26. Doulbles the value of food over drying.

\section{J. A. Wollier, Turmer, Me.:}

1. In the barn abont 10 feet from the stalls of the cittle.

3. $13 \times 12 \times 8$ feet high.

4. Hemlock loards, donble walls, space between filled with sawihst.

5. 2 incl plank.

6. Stone, 100 pounds to the square foot.

т.

8. Corm.

11. 12 tons per acre.

15. The ent forlec was simply rum into the silo from the cutter, leveled, and the cover laid m, and weighted. It was not trodken.

16. The entire cost of the fodder was $\$ 2.75$ per ton. The cost of cutting, hauling to the barn, and filling the silo, was $83 \frac{1}{8}$ eents per ton.

17. 54 disss.

18. Fermented just enongh to make it vergagreealblo to the eattle. A little around the outside was spoileri.

19. No deterioration.

20. There was a gain in the quantity of milk.

23. Part of the time we fed one bushel par day, and past of the time two bushels per day to rach eow.

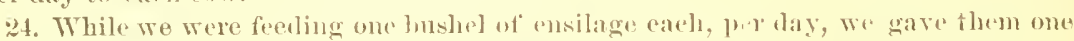
feed of hay w straw; when we fed two bushels jer lay, me fed on ensilage and shorts.

25. Thestock fed on ensilage gained in weight, and were in good health.

26. I think it is much more profitable than hay.

\section{E. Wrigit, Pleasut Hills, N. .J.:}

1. Two silos near feculing aller, and comnected ly rail tratelis.

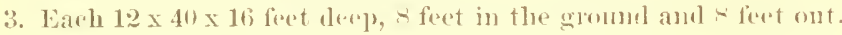

4. Stone, 18 inches thirk, laid in crmont at bottoun and lins-mortar higher up; partition wall 20 inches thirk.

6. Cement barrels lilled with samt, as many as can lay sicle by sidla.

7. Cost of two silos stou, hesiles the wool-morle.

s. Corll

9. Drills, a feet apart with a common grain drill.

10. When in full tassel aul silk, with eass well set. If allowed to turn yellow air takes the place of sal, and the crop is injured in the silo.

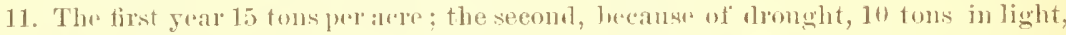
sandy soil and poor comblition. I believe 20 toms can la averaged.

1:. Hare plavtenl ilu. Jursey seed and sonthem whites: lattry l think may lue best, but am not sure.

14,15). As fine as 1 ('an, thee-eightlis to five-righths inch; machine run by steamengine: average 10 tuns per lour.

16. 35 cents per ton last year; the year before was meh more, probably lig delays ant breakages, reaching 502 or more.

17. If I required the stulf for feed I shomld open as soon as well settled, say two or three weeks, though I have never opened nuder two months.

19. Sour, apparently a vinegary aciul. I think this is not right, and may be avoitled by putting in when in full sip with no yellow stallis or leatves, putting in quickly and weighting heavily 300 to 400 pounds jer square foot. 
19. I do not think it deteriorates after it is opened. Have never seen any opened in warm weather, but am fixing for it.

20 to 25. Of my first year's ensilage I fed milel cows without mixing with other food, and conchded that its tendency was to dry them up. This year 1 mixed one quart of meal with each feed of 20 or 30 pounds twice a day, and once with dry hay. On such feeding the cows grew fat and gained slightly in milk.

26. If any profit at general farming can be extorted from the poor sandy soils of Sonth Jersey, it can only be done ly feeding cattle on ensilage.

\section{J. C. Whits, Mhitinsrille, Mass. :}

1. Convenient.

3. 44 feet long, 22 deep, 17 wide. Have two silos.

4. Built into a bank; 18-inch walls of flat stones, laid in cement; drain under the bottom of wall, constructed in most perfect manner with best masonry work.

5. Two-inch chestnut plank, laid crosswise, pointed so as to fit closely.

6 Stones, conrenient to handle, weighing fiom 80 to 100 pounds apiece; not less than 200 pounds to square foot.

8. Corn and rye. Would not use rye again.

9. Sweet corn planted in rows with planter, $3 \frac{1}{2}$ feet apart, 5 kernels to the foot. When 3 inches high go over it lengthwise with smoothing harrow-do that frequently, as long as fon can without breaking it over-then nse the common cultivator between the rows as long as practicable.

10. When the ear is half grown.

11. Alout 20 tons.

1:. Sanford's, or Stowell's Evergreen.

13. Consider it better than any field variety.

14. Cut three-fourths of an inch long.

15. Wo ent at the mper door, at top of silc. Men level and tramplo it.

16. Think it may be done for $\$ 1$ per ton.

17. About 2 months.

18. Perfectly good condition, exeept on top.

19. Not any. Abont 3 inches on top next the planks is moldy, below it is not affected. We always commence to cut on one end, and nerer remove the weights faster than we ent.

20. One-third of a tou of ensilage is equal to a ton of best English hay.

21. Think milk and butter are improved by the feed, hoth in quantity and qualut t. $^{\circ}$

22. Should use it mostly for ruminant aniuals; good for fittening.

23. 40 pounds on an ave age; fed twice a day, 20 pounds at a time.

24. Have never fed it alone. Put two quarts of some kind of meal with the ensilage each time it is fed, and give two or three pounds of hay to each animal just after the ensilage. At night we give middlings, or roots and hay.

25. Always a gain and good health.

26. Consider it profitable for evers one who keeps cows.

\section{Charles B. Ballard, Thite River Junction, Гt.:}

1. Silo parallel with cow barn.

2, 3. $20 \times 64 \times 26$ feet deep.

4. Stone and cement; the floor of stone, each $4 \times 6$ feet, and laid in cement.

5. Planks, with cobble stone about one foot in thickness.

7. About two thonsand dollars.

8. Virginia corn.

9. Planted with a one-horse planter and fertilizer. Harrowed when the corn was about one inch high. After that contivated it three times, abont once in ten days. 
10. Abont the time it begins to silk ont.

11. About 20 tons per acre.

12. Maryland and Virginia corn.

13. No earthly comparison.

14, 15. Cut np about one-fourth of inch, carried into silos by stationary engine.

16. \$1 per ton.

17. About thirty days.

18. Perfect, and will nerer change.

19. None.

20.

21. Increases quantity and quality.

22. \$4 per ton. Effects are good.

23. Seventy pounds per dav, with two quarts of cotton-seed meal, or corn meal, per head.

24. Feed alone.

25. Condition good, with perfect health.

26. Worth much more thau hay or any other iry feed. 
$$
\text { . }
$$ 
Mr 08 







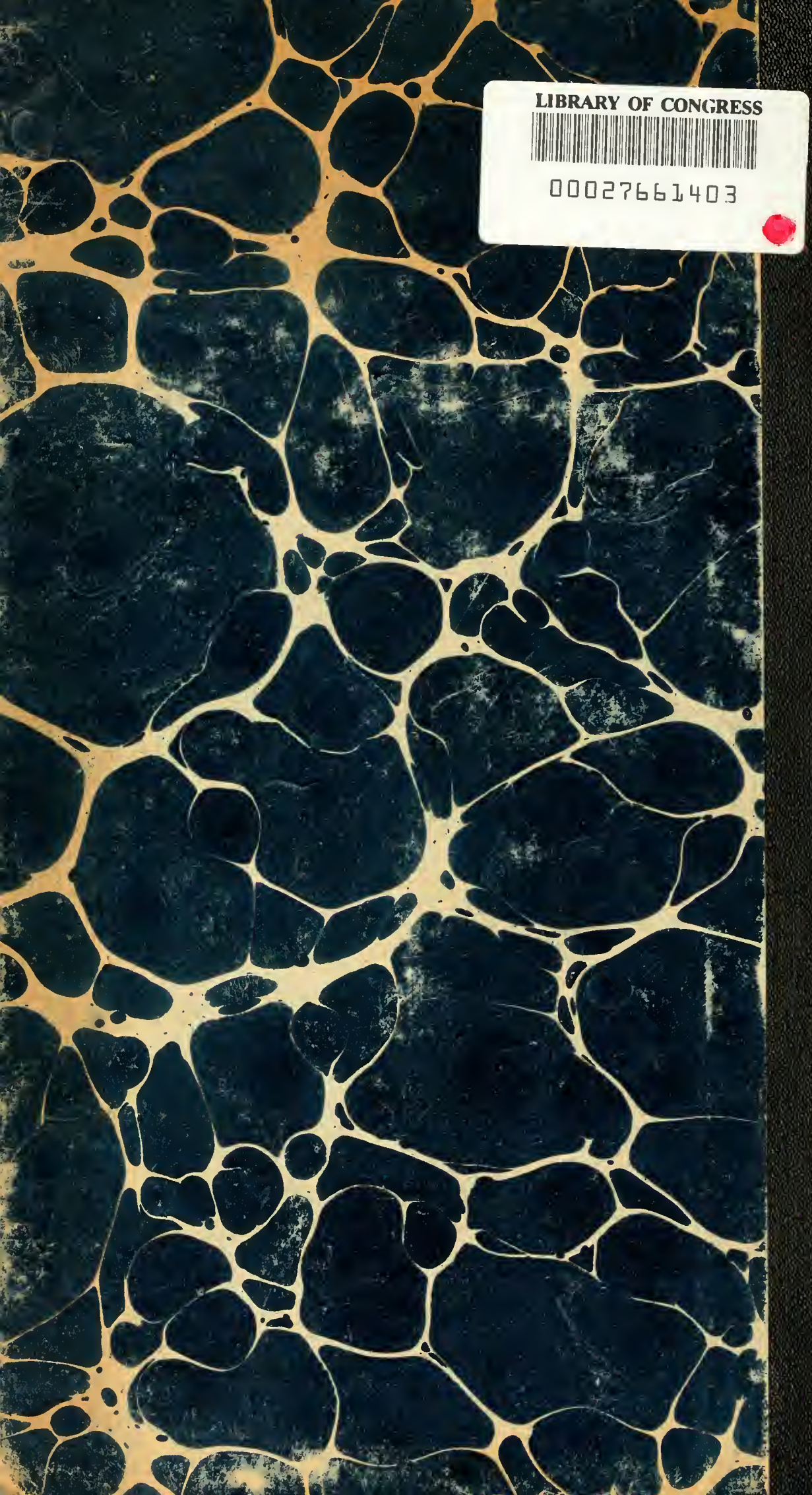

